Portland State University

PDXScholar

Spring 7-3-2013

\title{
No Place for Middlemen: Civic Culture, Downtown Environment, and the Carroll Public Market during the Modernization of Portland, Oregon
}

James Richard Louderman

Portland State University

Follow this and additional works at: https://pdxscholar.library.pdx.edu/open_access_etds

Part of the United States History Commons, and the Urban Studies and Planning Commons Let us know how access to this document benefits you.

\section{Recommended Citation}

Louderman, James Richard, "No Place for Middlemen: Civic Culture, Downtown Environment, and the Carroll Public Market during the Modernization of Portland, Oregon" (2013). Dissertations and Theses. Paper 1050.

https://doi.org/10.15760/etd.1050

This Thesis is brought to you for free and open access. It has been accepted for inclusion in Dissertations and Theses by an authorized administrator of PDXScholar. Please contact us if we can make this document more accessible: pdxscholar@pdx.edu. 
No Place for Middlemen: Civic Culture, Downtown Environment, and the Carroll Public Market during the Modernization of Portland, Oregon

by

James Richard Louderman

A thesis submitted in partial fulfillment of the requirements for the degree of

Master of Arts

in

History

Thesis Committee:

William Lang, Chair

David Horowitz

Jennifer Tappan

Barbara Brower

Portland State University

2013 
(C) 2013 James Richard Louderman 


\begin{abstract}
Following the Civil War, the American government greatly expanded the opportunities available for private businessmen and investors in an effort to rapidly colonize the West. This expansion of private commerce led to the second industrial revolution in which railroads and the corporation became the symbols and tools of a rapidly modernizing nation. It was also during this period that the responsibility of food distribution was released from municipal accountability and institutions like public markets began to fade from the American urbanscape. While the proliferation of private grocers greatly aided many metropolises' rapid growth, they did little to secure a sustainable and desirable form of food distribution. During the decades before and after the turn of the century, public market campaigns began to develop in response to the widespread abandonment of municipal food distribution.
\end{abstract}

Like many western cities, Portland, Oregon matured during the second half of the nineteenth century and lacked the historical and social precedent for the construction of a public market. Between 1851 and 1914, residents of Portland and its agricultural hinterland fought for the construction of a municipally-owned public market rallying against the perceived harmful and growing influences of middlemen. As a result of their efforts, the Carroll Public Market was founded on the curbsides of Yamhill Street in downtown Portland. While success encouraged multiple expansions and an increasingly supportive consumer base, a growing commitment to modernist planning among city officials and the spread of automobile ownership determined the market to be incompatible with the commercial future of Portland. 
In an effort to acknowledge and capitalize on the Carroll Public Market's community, a group of investors, incorporated as the Portland Market Company, worked with city officials between 1926 and 1934 to create the largest public market in the United States, the Portland Public Market. As the first building of the newly constructed waterfront development, many believed the massive institution would reinvigorate nearby businesses and ultimately influence the potential of the downtown business district. The Portland Public Market was decidedly distinct from the market along Yamhill and the promoters cast it as such. By utilizing the most modern technologies and promises of convenience there was little that the two organizations shared in common. In the end, the potential of the waterfront market was never fulfilled and amidst legal scandals, an ongoing struggle to meet operating costs, and the success of a rebellious Farmers Cooperative, it shut down after nine years.

This thesis discusses these two public markets during a period of changing consumer interests and the rise of modernist planning in Portland, Oregon. Ultimately, the Carroll Public Market was torn down for reasons beyond its own control despite the comfortable profit it enjoyed each year. Many city officials refused to support the institution as they increasingly supported the values of modernism and urban planning. The Portland Public Market fit perfectly with many city planners' and private investors' intents for the future. This essay seeks to offer a unique glimpse of how commercial communities form and how commercial environments evolve through the politics of food distribution, consumerism, and producer-to-consumer relationships. 
I would like to dedicate this thesis to my parents, the doors they have opened for me, and a camping trip in the Rocky Mountains that forever altered the course of my life. 
Table of Contents

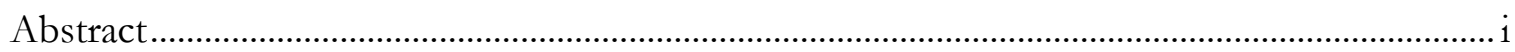

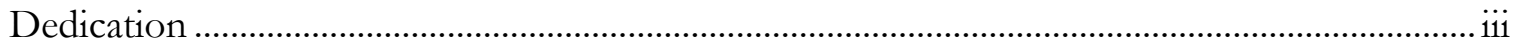

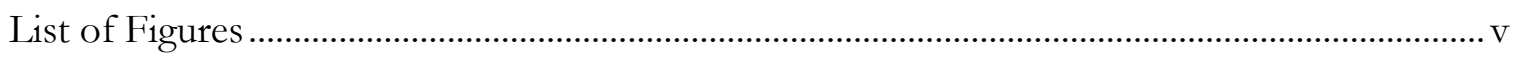

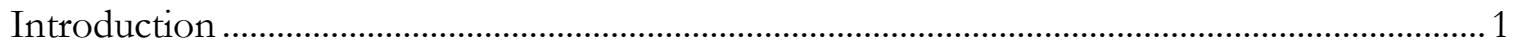

Chapter One

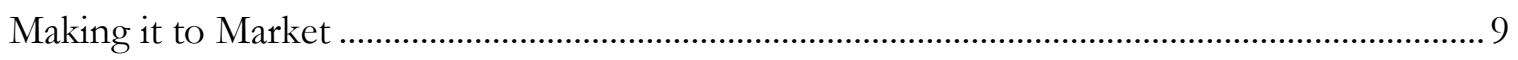

Chapter Two

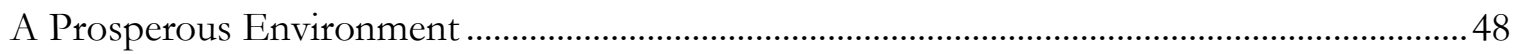

Chapter Three

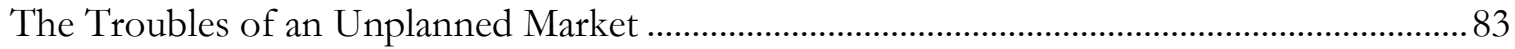

Chapter Four

The World's Most Modern Food and Merchandise Mart..........................................................107

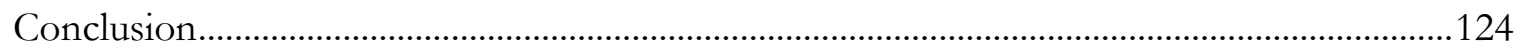

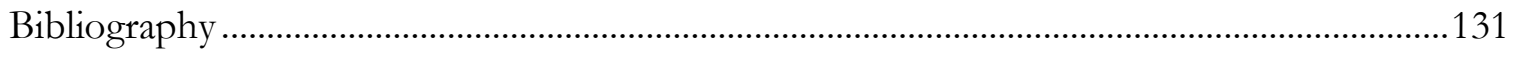




\section{List of Figures}

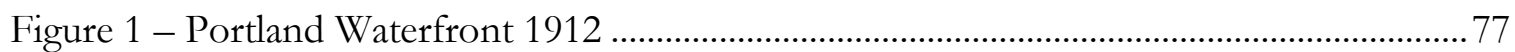

Figure 2 - The Carroll Public Market Street Side........................................................................... 78

Figure 3 - Bartholomew's Map of Downtown Portland .........................................................

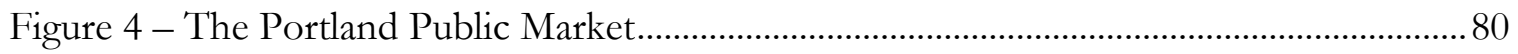

Figure 5 - Inside Portland's Million Dollar Market ................................................................... 81

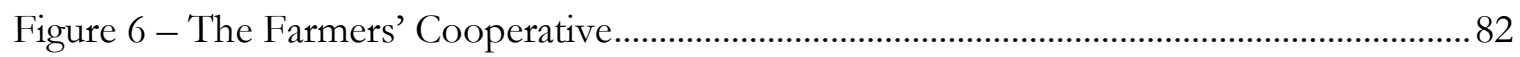




\section{Introduction}

According to the Municipal Markets Report of 1918 conducted by Director Sam L. Rogers of the Bureau of the Census, "A municipal market should be self-supporting, but should not be operated for any considerable profit. A municipal market can justify itself only by supplying to its patron some advantages not supplied by a privately owned public market." ${ }^{1}$ The logic may not entirely continue today for the remaining public markets of America, but in the early twentieth century, these institutions were seen as tools that provided the urban public with lower prices, fresher food, and in many cases, food that neighborhood consumers otherwise did not have access to. Farmers also supported the public market because it gave them better prices on the produce they worked year-round to create. The Census report did not detail the motivations of urban and rural citizens for the establishment of public markets let alone the history that spawned the American public market movement during the early twentieth century. Of all the different values that people found in public markets during this period, there was one that nearly everybody shared; the elimination of the middleman. ${ }^{2}$

Generally speaking, middlemen constituted every person in between the producer and the consumer that raised the price of the product throughout the process of distribution. While the term middleman may have initially referred to businessmen and merchants in the early decades of the nineteenth century, by the end of the 1800 s it was also ascribed to those who transported goods (particularly the railroads), the speculator, and anyone else who made

\footnotetext{
${ }^{1}$ U. S. Bureau of Census, "Municipal Markets in Cities Having A Population of Over 30,000: 1918," Prepared by Sam L. Rogers, Washington, DC: Government Printing Office, 1919.

${ }^{2}$ Helen Tangires, Public Markets and Civil Culture in Nineteenth Century America (Baltimore: John Hopkins University Press, 2002), 204-205.
} 
money off of a producer's products. This broader definition and re-focusing on the middleman was partly the product of political movements but it was also a reaction to a monumental growth in the commercial structures that operated within the country. The rise of corporate power changed the way private enterprise worked and how citizens interacted with it; the late nineteenth century constituted a fairly abrupt redefinition of the commercial landscape.

Many of America's major cities were founded prior to this period, but some, like Portland, Oregon, grew up in the midst of it. Unlike many East Coast cities, Portland did not operate a municipally-owned public market until 1914: the Carroll Public Market. Motivations for its construction were similar to that of many other metro areas during the early twentieth century but because it constituted an origin point for municipally-operated food distribution in Portland, it held substantial cultural value for those that supported it. The market operated along the curbs of Yamhill Street between First and Fifth streets for almost twenty years before being replaced by the Portland Public Market, a much larger and more modern upgrade, in 1934. The Portland Public Market lasted until 1942, though it was never able to make enough money to meet its operating costs and struggled to attract patrons. These two public markets were nearly perfect opposites and both were constructed by different values and understandings of the institution. The Carroll Public Market enjoyed a healthy degree of allegiance from producers and consumers during its life because it had a strong cultural foundation and that support was robust enough to influence and change the commercial environment around it on Yamhill Street.

This thesis seeks to understand why and how the Carroll Public Market was dramatically more successful than the Portland Public Market. Broadly speaking, this thesis is 
also a detailing of the interplay between cultural forces and environmental change in downtown Portland. The term cultural foundation refers to both the value that was quickly prescribed to the institution and the community that supported its operations. The Carroll Market was a response to decades of social, political, and commercial changes in Oregon and it was because of those developments that certain groups found worth in it. Taken together, these factors provided support for developments to the market and Yamhill Street. Over the market's life, Yamhill Street was transformed in a variety of ways: the market's vending sheds were expanded down the street multiple times, the buildings behind the market were given large sidewalk awnings, many basements were transformed into storage units for the farmers, and most notably, every store behind the curbside market became either a grocery, a privately-owned public market, or some other manner of food sales. In a relatively short period of time, the Carroll Market became the centerpiece and inspiration for a greater market district along Yamhill; a new and distinct commercial environment.

The notion that public markets have direct effects on their social and commercial environments is not entirely unique to this thesis. Academics like Alfonso Morales suggest that public markets have historically been tools of entrepreneurial opportunity and business incubation. ${ }^{3}$ Morales asserts that public markets like Maxwell Street in Chicago allowed local government to "address unemployment, enhance food security, and incorporate new immigrants as a part of a larger plan for economic development." ${ }^{\prime 4}$ Due to these benefits, the market also served as what he calls a "place maker," meaning the public market drew attention to the neighborhood it occupied and gave it cultural significance. In the case of

\footnotetext{
3 Alfonso Morales, "Public Markets as Community Development Tools," Journal of Planning Education and Research (February 25, 2009): 426.

${ }^{4}$ Morales, "Public Markets as Community Development Tools," 436.
} 
Maxwell Street, many of the neighboring retail businesses were what one observer during the 1920s called "graduates of Maxwell Street." Their businesses had grown up with the Maxwell Street Market and remained a part of the community as they prospered. In Portland, a similar experience occurred with Fred Grubmeyer on the choicest intersection of the market, Yamhill and Fifth streets. Grubmeyer opened a small drug store in 1922 that flourished in the backdrop of the Carroll Public Market and from that location, the Fred Meyer grocery chain began. ${ }^{6}$ Despite the commercial and community "incubation" that occurred on Yamhill Street, the market was torn down in 1934.

In the end, the motivations for replacing the Carroll Public Market with the Portland Public Market had little to do with the profitability, wholesomeness of the food, cost of the produce, or consumer support of the market. Nearly every year the market was open, it produced profits that exceeded twice the operating costs; a testament to the producer and consumer support it generated. The most significant reason it did not keep expanding along Yamhill, was the growth of Portland's central business district during the 1910s and 1920s. The commercial importance and congestion of downtown Portland grew quickly during the initial decades of the twentieth century due to the efforts of urban planners, businessmen, and the proliferation of automobiles. As a popular curbside institution, the Carroll Market exacerbated traffic conditions of both automobiles and pedestrians. By replacing the market on Yamhill, planners hoped to create a new commercial district along Portland's waterfront and free up Yamhill for future downtown development. The Portland Public Market was

\footnotetext{
5 Morales, 437.

6 "Fred Meyer History," Fred Meyer Website. http://www.fredmeyer.com/company_information/pages/history.aspx (accessed on January 25, 2013). 
intended to be a symbol of modernity and a central component of modernizing Portland, aspects that intentionally contrasted with the Carroll Market.

There has been little scholarly work done on American public markets, especially so in the context of urban modernization and commercial development. Helen Tangires' book, Public Markets and Civil Culture in Nineteenth Century America (2002), addresses the history of public markets in the United States during the nineteenth century. ${ }^{7}$ Her research focuses exclusively on market buildings by examining changes in market law and public market structures. Tangires claims that during the nineteenth century, American public markets did not fail because of natural takeovers by corporate or private interests but rather these institutions survived and adapted in different forms because of their inherent civic qualities. In many cases no particular institution could forever endure private competition and rapid urban development. From the late nineteenth century onward, public markets became tools rather than accepted municipal utilities and were often used as solutions to food distribution problems, not unlike the Carroll Market. Tangires also illustrates that while the nineteenth century is generally understood to be a period of loss in the "moral economy," the constant resurgence of public markets and similar institutions displayed the public's resilience for and insistence in enforcing the "moral economy." This thesis hopes to add to the expanding literature on public markets by understanding the traceable causes and effects of one public market rather than a nationwide survey.

The historical field of American consumerism and food distribution has only just recently started to include the role of public markets. Tracy Deutsch's book, Building a Housewife's Paradise: Gender, Politics, and American Society in the Twentieth Century, has shown how

\footnotetext{
7 Tangires, Public Markets and Civil Culture in Nineteenth Century America, 204-205.
} 
America's food distribution system evolved throughout the twentieth century to meet the needs of its most common shopper; the housewife. ${ }^{8}$ The success of larger retailers over small grocery stores, public markets, and "mom and pop" places was a complicated evolution that sought to make shopping easier, reduce total inefficiencies, and respond to the criticisms of female shoppers. Deutsch explains, like Tangires does, that this progression was made possible because of consumers and was not solely the result of aggressive commercial management. In the end, Deutsch confirms that the female grocery shopper was always the central focus of retailers and politicians postulating about food distribution in the twentieth century. Both of Portland's public markets relied heavily on the assumption that they were primarily serving housewives and this had a profound impact on how they were regulated and structured.

Public markets are also shaped by their regions, and by their nature constitute a collection of local farmers/producers. The public market movement of the early twentieth century was nationally widespread but initiated by local urban and rural advocates. Books like D. W. Meinig's The Shaping of America: A Geographical Perspective on 500 Years of History, Volumes III and IV and Empire of the Columbia: A History of the Pacific Northwest, by Dorothy O. Johansen and Charles M. Gates provide geographical histories that have been essential for constructing the details of Portland's commercial network. 'These books have also provided information regarding the agricultural, environmental, and economic changes that took place in the region leading up to the construction of the market. William Cronon's Nature's

\footnotetext{
${ }^{8}$ Tracy Deutsch, Building a Housewife's Paradise: Gender, Politics, and American Grocery Stores in the Twentieth Century (Chapel Hill: University of North Carolina Press, 2010).

${ }^{9}$ Dorothy Johansen, Empire of the Columbia a History of the Pacific Northwest 2nd ed. (New York: Harper \& Row, 1967); and D. W. Meinig, The Shaping of America: A Geographical Perspective on 500 Years of History Continental America, 1800-1867 (New Haven: Yale University Press, 1993).
} 
Metropolis is written within a similar vein but attempts to assert how the larger constructions of commercial networks were tied to the growth of Chicago. ${ }^{10}$ This book has influenced a great deal of the methodology used in the first chapter of this thesis. Cronon does not discuss public markets but he does detail how urban and rural spaces became increasingly interconnected by commercial development during the nineteenth century. The new commercial connections often intensified social and economic inequality, a problem that certainly instigated many communities to create their own municipal markets.

Books like Robert F. Fogelson's, Downtown: Its Rise and Fall, 1880-1950, have been helpful for understanding the national trends of commercial consolidation that occurred within urban environments during the first half of the twentieth century. ${ }^{11}$ The growth of Portland's downtown contributed greatly to both the success and the failure of the Carroll Public Market. According to Carl Abbott's book, Portland: Planning, Politics, and Growth in a Twentieth Century City, Portland's downtown was protected by city planners who actively sought to control the dimensions and location of a central commercial district for the entire city. ${ }^{12}$ The ideology of planning in Portland was strongly valued throughout the twentieth century and it ran counter to the survivability of the Carroll Public Market's community of producers and consumers. As a result, the Portland Public Market was built with no support from the social and political groups that had founded the market on Yamhill. E. Kimbark MacColl's books, Merchants, Money and Power: The Portland Establishment 1843-1913; The Growth of a City: Power and Politics in Portland, Oregon, 1915-1950; and The Shaping of a City: Business and Politics in Portland, Oregon, 1885-1915 have all been useful for providing the many details of

\footnotetext{
${ }_{10}$ William Cronon, Nature's Metropolis: Chicago and the Great West (New York: W. W. Norton \& Company, 1991). ${ }_{11}$ Robert M. Fogelson, Downtown: Its Rise and Fall, 1880-1950 (New Haven: Yale University Press, 2001). ${ }^{12}$ Carl Abbott, Portland: Planning, Politics, and Growth in a Twentieth Century City (Lincoln: University of Nebraska Press, 1983).
} 
Portland's commercial, political, and social history. ${ }^{13}$ Most of these books discuss the public markets of Portland little if at all. This thesis will connect the greater stories of the state and the city to the Carroll Public Market and will seek to bring more relevance to a piece of Portland's history that deserves more attention. The Carroll Market altered the discourse of food distribution in Portland and constituted an institutional origin point for anti-middlemen and producerist values in the city's ideas of food distribution.

The thesis is divided into four chapters: Making it to Market, A Prosperous Environment, The Troubles of an Unplanned Market, and The World's Most Modern Food and Merchandise Mart. The first chapter details with the creation of the market's cultural foundation, or how the commercial divide between rural and urban places that encouraged Portland's public market campaign. The next chapter addresses the growth of Portland's downtown district and how the Carroll Public Market shaped its commercial environment. The third chapter discusses the rise of urban planning in Portland and the effort to replace the market on Yamhill with a modernized waterfront superstore. Finally, the last segment focuses on the Portland Public Market as a symbolic rejection of what made the Carroll Public Market work. In comparison, the two markets held different ideas of what a public market was, who valued it, and how it could be implemented, a distinction that had a direct effect on the fate of the Portland Public Market.

\footnotetext{
13 E. Kimbark MacColl and Harry H. Stein, Merchants, Money and Power: The Portland Establishment 1843-1913 (Portland: The Georgian Press Company, 1988); E. Kimbark MacColl, The Growth of a City: Power and Politics in Portland, Oregon, 1915-1950 (Portland Or.: Georgian Press, 1979); and E. Kimbark MacColl, The Shaping of a City: Business and Politics in Portland, Oregon, $1885-1915$ (Portland Or.: Georgian Press Co., 1976).
} 


\section{-Chapter One-}

\section{Making it to Market}

On May 16, 1914, an uncommonly "fair and warm" day for western Oregon in the middle of spring, the city of Portland celebrated. ${ }^{1}$ After a decade of frustrations and over a year of aggressive campaigning by the city's various clubs, organizations, and social elite, Portland finally had a public market in its downtown. The Carroll Public Market was named after John Carroll, the editor of the Evening Telegram and one of Portland's most vocal advocates for a public market system of food distribution. For the opening day, farmers arrived as early as five in the morning to set up along Yamhill street's curbs from Fifth to Third, and started selling two hours later. After the official opening at ten o'clock, a parade was held to commemorate the event with "Thousands of representatives of commercial organizations, granges, local business concerns, and booster clubs... which extended in a winding course practically from the Broadway Bridge to the market entrance (roughly a mile in distance)." With such a wide variety of citizens there to support the market, it was not surprising to see the producers sell out completely, of "more than one hundred wagon loads of farm produce" by 2 o'clock. ${ }^{3}$ Support from social and political groups remained strong throughout the decades as the market expanded and grew. The Carroll Market remained in Portland until January 1, 1934.

Unlike cities in the Midwest and on the East Coast, Portland's early formative years were in the decades after the Civil War during a time of growing federal and corporate

\footnotetext{
1 “Index of Today's News (And Weather)," Oregonian, May 16, 1914.

2 "Pageant in which Thousands Participate Marks Formal Opening of Portland Public Market on Yamhill Street," The Morning Oregonian, May 17, 1914.

3 "Pageant in which Thousands Participate Marks Formal Opening of Portland Public Market on Yamhill Street," The Morning Oregonian, May 17, 1914.
} 
influence on economic growth. ${ }^{4}$ While many older cities on the East Coast had once controlled municipal markets, Portland's first (and only) was the Carroll Public Market. Understanding the social, cultural, and environmental conditions leading up to its inauguration in 1914 can give insight into the historical forces that developed and formed the market's cultural foundation. The Carroll Public Market was a symbol of the connections that had been made between Portland and its agricultural hinterland. It also represented the political ideologies of communities that constituted the Populist and Progressive movements of the period, resulting in a physical and cultural relationship between producers and consumers.

The values and places that defined the market positioned it within a framework of historical and cultural momentum that resulted in its construction and sustained community involvement. This is not to suggest that the market only succeeded because of cultural support, but it is important to recognize the historical and cultural contexts that made this market important in the way that the people who believed in it might have. Creating and maintaining a municipal market in Portland, the metropolitan commercial center of the entire state, advertised relationships between urban and rural places that many Oregonians valued. This chapter seeks to analyze the historical motivations behind the market and describe why it was valued as an emblematic place of commercial, geographic, and political relationships. ${ }^{5}$

\footnotetext{
${ }^{4}$ Alan Trachtenberg, The Incorporation of America: Culture and Society in the Gilded Age (New York: Hill and Wang, 2007).

${ }^{5}$ For more on public markets, see: George Eigo, A Market for the City: The History of Portland's Public Market (Portland: Oregon Historical Society, 2002); James M. Mayo, "The American Public Market," Journal of Architectural Education 45, no. 1 (November 1, 1991): 41-57; and Helen Tangires, Public Markets and Civic Culture in Nineteenth-Century America. (Baltimore: John Hopkins University Press, 2002).
} 
The roots of the Market's support were forged with the creation of two relationships: Rural to Urban, and Populist to Progressive. As Oregon developed, cities like Portland took on different roles than they had had previously. Industrial, technological, and capitalistic changes throughout the nineteenth century allowed and encouraged cities to become economic focal points for larger amounts of commercial activity and immense tracts of agricultural land. The creation of the "Rural to Urban" relationship was physical and ideological. Portland's location at the meeting point of the Columbia and Willamette Rivers encouraged commercial centralization and distinct place identification. This relationship was created from commercial and geographic motivations, but it became charged with cultural and political value as the city and state evolved. As more people migrated to Oregon in the late nineteenth and early twentieth centuries, they, like the rest of the country, questioned the monumental transformations to their environments and livelihoods wrought by greater industrialization.

During Oregon's maturation, the rise in political ideology played an important role in associating specific populations with politics. The Populist Movement of the late nineteenth century was a grassroots campaign that began with farmers, and was one of the earliest political forces to challenge corporate capitalism. As that movement faded during the early twentieth century, Progressivism gained momentum in urban centers. ${ }^{6}$ While the transition between these political movements was different in many states across the country, Oregon experienced a seamless evolution. In Oregon, these two groups did not find themselves at odds and their ideological similarities helped to develop the "Populist to Progressive" ${ }^{6}$ Robert Johnston, The Radical Middle Class: Populist Democracy and the Question of Capitalism in Progressive Era
Portland, Oregon (Princeton N.J.: Princeton University Press, 2003), 10-11. 
relationship. These movements are most important for recognizing how they politically charged urban and rural communities in Oregon.

The culmination of these two sets of relationships ultimately encouraged the ideology of "Producers to Consumers." This connection was specifically addressed in places like public markets, but its rhetoric and principles permeated a variety of businesses and organizations during the early twentieth century. Producers and consumers fought against the detriment of "middlemen," and placed themselves within the geographical category of localism in which government could (and should) be used for the betterment of the people. John Carroll described the situation best in one of his many editorials advocating for the construction of a public market titled, "Market Needs:"

There is a general problem of distribution and there is a local problem. If all the profits of the producers are eaten up between the time the product leaves the hands of the producer and the time it reaches the consumer then it is a matter of distribution cost and middlemen. There is no greater public need and there is nothing that would so largely benefit the buying public in Portland and the producing public in the surrounding region. ${ }^{7}$

Carroll expressed sentiments felt by many people throughout Oregon; the profiteering of middlemen hurt producers and consumers by driving up costs and lowering quality. During the decade before the construction of the Carroll Market, the role of the "middlemen" was debated between varieties of groups, but populists of the Grange took the lead in establishing the framing of the problem. E. E. Blanchard, a representative from the Josephine County Grange and the principal speaker of a special Grange meeting in December of 1913 stated that "co-operation" between the farmer and retail merchant was necessary to "cut out" the commission merchant. ${ }^{8}$ Cooperation, Blanchard believed, would be equally beneficial to both parties. The issue of food distribution had long been a sensitive

7 John Carroll, "Market Needs," The Evening Telegram, April, 21, 1913.

8 "Mutual Aid is Proposed," The Oregonian, December 18, 1913. 
subject for both producers and consumers. Before the late nineteenth century, public markets were customary solutions and expected institutions of food distribution in America. Understanding the history of these relationships that formed the market's cultural support allows one to see the Carroll Market within its historical context as a cultural and geographical institution of producers and consumers. It was this context that allowed the Carroll Market to maintain a supportive community even after its replacement in 1934.

\section{“The City That Gravity Built:" Rural to Urban}

The West's first American settlers were deserters. ${ }^{9}$ For over a century, eastern American farmers had worked their land unsustainably and by 1840, much of it had lost its fabled fertility. ${ }^{10}$ Moving westward had become typical. With an abundance of cheap or free land to the west, immigrants and capitalistic farmers became the pioneers of westward economic and social expansion. Rumors of the Northwest's moderate climate, inexpensive land, and agricultural possibilities were tempting to these settlers, to say the least. Between 1840 and 1860, the Oregon Trail directed over 53,062 people to the Northwest, most of them farmers. ${ }^{11}$ Before Oregon was a state, geographical destinations like the Willamette Valley and the Columbia River became legendary as potential agricultural paradises because they resembled the farmland of the original colonial states. Despite the possibilities that Oregon's land presented, the region grew slowly. Only the most committed and adventurous

\footnotetext{
${ }^{9}$ Phrase taken from: Johansen, Empire of the Columbia a History of the Pacific Northwest, 267.

${ }^{10}$ Steven Stoll, Larding the Lean Earth: Soil and Society in Nineteenth-Century America 1st ed. (New York: Hill and Wang, 2002).

${ }^{11}$ John David Unruh, The Plains Across: The Overland Emigrants and the Trans-Mississippi West, 1840-60 (Chicago: University of Illinois Press, 1979), 119-120.
} 
families made the two thousand mile journey from Independence, Missouri. ${ }^{12}$ Alongside the families of farmers, businessmen, capitalists, and wealthy eastern families looking to seize profitable opportunities also arrived, beginning the process of urbanization. Not unlike other developing American states during the nineteenth century, the residents of Oregon desired a central city for negotiating economic activity. This began the development of a physical relationship between Oregon's rural community and its urban centers.

During Oregon's time as a territory between 1848 and 1859, boosters from different cities competed and attempted to promote their location as the regional center. ${ }^{13}$ Initially, many saw Oregon City, the terminus of the Oregon Trail due to the Willamette Falls, as the capital of the Northwest and it informally acted as such during that time. Oregon City was believed to hold the centralizing potential for commercial activity, but contending with Portland became impossible, due to its role as a port near the intersection of the Willamette and Columbia rivers and by 1859, when statehood was achieved, even more settlers arrived. Positioned as a historic stopover for fur trading institutions like the Hudson's Bay Company, Portland quickly surpassed other population centers in trade activity. ${ }^{14}$ Greatly aided by geography, thousands of new farmers found economic potential in the future metropolitan site.

With the Willamette flowing north and the Columbia flowing west, Portland rested in the basin of the state's agricultural, economic, and migratory activity. It has been aptly described as the "city that gravity built." From the city looking westward, boosters imagined

\footnotetext{
${ }^{12}$ Carlos Schwantes, The Pacific Northwest: an interpretive history (Lincoln: University of Nebraska Press, 1989), 8689.

${ }_{13}$ Meinig, The Shaping of America. a Geographical Perspective on 500 Years of History Continental America, 1800-1867, 71-73.

${ }^{14}$ Johansen, Empire of the Columbia a History of the Pacific Northwest, 278.
} 
the potential. The Columbia River fed out into the Pacific Ocean, presenting trade possibilities with the rest of the West Coast and Asia. Despite its seemingly ideal position in the Northwest, the city and its adjacent agricultural paradises along the rivers were still isolated from the country in 1860. As late as the early 1870s, Portland was the only outlet for the Willamette Valley's rich variety of agricultural products. ${ }^{15}$

Some of the very first trade routes existed along Oregon's waterways where the Hudson's Bay Company (HBC), a British fur trading institution, had pioneered commerce in the region. Since the seventeenth century, their ships and army of fur traders moved along those routes, constructing a geographical awareness that prioritized the waterways. In the early nineteenth century, the headquarters for the region was controlled from Fort Vancouver by John McLoughlin on the Columbia River, just north of Portland's future seat. ${ }^{16}$ With the advent of the Oregon Trail, America's growing regional population in the Northwest weakened the control of the company and further opened the possibility of settlements. Established traders of the region like McLoughlin played an important role for settlers as early guides and entrepreneurs. ${ }^{17}$ As the region became more populated, traders used their knowledge of developed trade routes and geography to become entrepreneurs, thus helping to construct a comprehension of the region's potential economic web, one that saw the future seat of Portland as a commercial center.

With a definitive economic focal point, urban and agricultural development up and down the rivers increased between 1860 and 1870, establishing an international web of

\footnotetext{
15 Johansen, Empire of the Columbia a History of the Pacific Northwest, 282.

${ }_{16}$ Carl Abbott, Portland in Three Centuries: The Place and the People (Corvallis: Oregon State University Press, 2011), 14-16.

${ }_{17}$ While many Americans in Oregon detested John McLoughlin in 1850, as early as 1915, McLoughlin had earned the title "Father of Oregon" and "Founder of Agriculture in the Pacific Northwest" for his general store in Oregon City and aid given to early pioneers. Leslie M. Scott, "Soil Repair Lessons in the Willamette Valley (Part 1)," The Oregonian, February 14, 1915.
} 
commerce from farms to towns to Portland and out of the state. Along the Willamette Valley, Salem, Corvallis, and Eugene became the commercial connections to the city. By the late nineteenth century, The Dalles served farmers of the Columbia River and Mount Hood's northern slopes. This emerging network produced only enough for the region, and trade outside of it was limited. While Portland may have been geographically advantageous as a commercial port, it was also the belief in its potential that dictated the pace and place of Oregon's economic and social evolution for much of its early life.

Prior to statehood, steamboats were an early and vital mode of transportation and commerce for Oregon. Steamboats were first used by the Hudson's Bay Company in 1836, and some, like the Beaver, were important initial passenger and supply carriers in the decades leading up to $1860 .^{18}$ During the West Coast gold rushes (roughly 1850 until 1870) steamboat transportation exploded. By 1860, dozens of steamboats ran the waterways of Oregon. Major companies like the Oregon Steam Navigation Company and the People's Transportation Company ran regular service up the Willamette and out the Columbia from The Dalles. ${ }^{19}$ For over a decade, the two companies controlled the waterways and provided most of the state's transportation needs. Years later in the 1880s, the Northern Pacific Railway swallowed up the Oregon State Navigation Company, further enhancing the size and scope of their monopoly over farmers.

While the Portland grew in economic significance, roads leading to it were always in demand. Because of its location though, forming dedicated navigable highways beyond the routes of the waterways proved difficult. Many roads were built in the initial decades of

\footnotetext{
18 Schwantes, The Pacific Northwest: an interpretive bistory, 150.

${ }^{19}$ Oregon's flattest terrain lay in the dry southeastern portion of the state where farms and settlement was less desirable because of increased startup costs and distance from Portland. Johansen, Empire of the Columbia a History of the Pacific Northwest, 279-281.
} 
statehood but most of them were links to waterways or ran alongside them. Roads were crucial for allowing agriculture to expand around different towns but they also promoted the geographical network of commercial centers that flowed toward Portland. Prior to the transcontinental railroads, nearly every mode of transportation was dictated by topographical constraints and the waterways' flow of trade into the basin of Portland. ${ }^{20}$

Early railroads were essentially redundant to the other forms of navigation. While this encouraged a sense of regionalism, it was mostly a byproduct of isolation. As Portland began to see trickles of economic engagement outside of the region during the 1860 s for products like wheat and wool, it still lacked a formidable economic route that could facilitate widespread development. All of this began to change after 1862, when Congress passed the Pacific Railroad Act, which sought to connect the coasts by issuing government subsidies and land grants to railroad companies. ${ }^{21}$ After the completion of the first transcontinental railroad in 1869, rail construction boomed as capitalists and investors imagined economic possibilities into existence. For the Northwest, the period between 1870 and 1880, marked the expansion of rail lines outwards from its major cities, connecting the region more efficiently and completely than it had ever been. ${ }^{22}$

Portland's first transcontinental railroad did not appear until 1883 with the Northern Pacific that linked it to St. Paul, Minnesota, and subsequently the rest of the Midwest. By 1887, railways were completed southward, giving the city a direct route to San Francisco.

\footnotetext{
${ }^{20}$ Meinig, The Shaping of America, 73-75.

${ }^{21}$ Railroads banded the country together, encouraging a greater need for standardization, and elevating the ideology of the industrial metropolis. They were the also the first of many modern technologies to reduce geographical limits of cultural regionalism across the country. While that process took over a century to fully mature, priority to economic regionalism faded in a few short decades. With railroads, cities truly became economic and social centralizers for regions and states. The first transcontinental railway was finished in 1869, connecting New York and San Francisco by a mere six days of travel. Meinig, The Shaping of America, 23.

22 Schwantes, The Pacific Northwest: an interpretive history, 153-157.
} 
Connecting to other states' commercial metropolises was economically efficient but it also encouraged growing cultural and political differences of interest between urban and rural residents. Both parties interacted with the railroad in diverse ways but farmers often took the brunt of railroad companies' economic clout, losing much of their profits before their products made their way to consumers.

For the country as a whole, the impact of the rail lines was complex beyond comprehension. Economic gains made during the time were nominal in comparison to the long-term social and cultural changes that infected every federal, financial, corporate, and domestic sphere in the nation. ${ }^{23}$ Not unlike the "gravity" that made Portland's location ideal for waterways, decades of economic and social flow towards the city had developed significant monetary mass, making Portland an obvious target for railroad expansion. Until the 1890s, Portland remained the single most important port for all of the Northwest. ${ }^{24}$ Railways leveled the playing field for many major cities but forgot everything smaller. This encouraged new competition among the major ports and urban centers, initiating capitalistic rivalry between cities like Portland and Seattle. For the city and its hinterland, the rails brought new opportunities and enterprise at the cost of cementing a permanent relationship of economic dependency within a hierarchy of commercial centers. This also guaranteed that urban and rural places would be separated in more ways than just geography.

As William Cronon has asserted in Nature's Metropolis, the perception of America as a commercial empire among boosters and others allowed them to believe "that the flow of 'tribute' among its various parts enriched all and impoverished none. The progress of cities

${ }^{23}$ Trachtenberg, The Incorporation of America: Culture and Society in the Gilded Age, 38-44 and 121-126.

${ }^{24}$ Johansen, Empire of the Columbia a History of the Pacific Northwest, 317-320. 
and their rural areas opened markets that enabled both to prosper." ${ }^{25}$ Cronon goes on to state that the "exchange was anything but a zero-sum game...if rural areas failed to become tributary to a metropolis, they would have no market..." The rapid expansion of many urban metropolises complicated localized exchange processes like food distribution. In the eyes of many urban boosters, rural space that radiated out from the metropolises could be considered the city's hinterland. Thus rural and urban spaces were part of the same commercial system but modeled with the ideology of imperialism. ${ }^{26}$ The growing social, cultural, and economic divide between rural and urban places during the nineteenth century was arguably exacerbated in larger cities like Chicago due to the sheer size and economic clout they developed in such a short period of time. Portland, on the other hand, experienced a slower and steadier growth that allowed for the maintenance of a cultural bridge between the city and the hinterland. Farms and their producers remained an integral part of Portland's economic output well past the turn of the century.

After the railroads came, agriculture in the Valley diversified beyond wheat. For decades, Oregon's farmers had mainly grown wheat because it held a high demand in Russian-Alaska. This trade relationship was initially facilitated by the $\mathrm{HBC}$ and began in the 1840s. ${ }^{27}$ Wheat was also a common staple, requiring little upfront capital and agricultural knowledge and within their isolated markets, farmers had always considered it a safe investment. Coinciding with the new iron connections of trains, agricultural innovation and technical knowledge of farming increased exponentially around the country. ${ }^{28}$ When railways

${ }^{25}$ Cronon, Nature's Metropolis, 45.

${ }^{26}$ Cronon, Nature's Metropolis, 47.

${ }^{27}$ James R. Gibson, Farming the Frontier: The Agricultural Opening of the Oregon Country 1786-1846 (Seattle: University of Washington Press, 1985), 136-141.

28 As the nineteenth century began to end, agriculture had taken over much of the government's domestic interests and efforts. Farms were one of the first places to experience new dedications to scientific 
came to Portland, they brought with them a new age in farming thus changed the nature of Oregon agriculture as well as the people that worked the land. Purebred cattle, sheep, horses and new crops, along with new tools, equipment and machinery came by rail with businessmen and "gentlemen farmers." 29 Many of these new farmers were interested in large operation investments and diversifying Oregon's market potential. Changes occurred rapidly, and by 1915, reliance on wheat diminished as new types of farms like commercial orchards had become common. ${ }^{30}$ While this change had begun over a decade prior to Portland's first transcontinental rail, the new connection allowed for a more rapid economic transformation and a sizable influx of wealthy easterners.

Throughout the 1880s, over fifteen thousand new farms went into cultivation in the Northwest. ${ }^{31}$ Large-scale farms operating for commercial export began to speckle the countryside alongside the small, older family farms in greater frequency. As was true all over the country, the Panic of 1873 had devastated small farmers and had begun a process of land consolidation for the wealthy "gentlemen farmers." While this drastically altered the manner and culture of farming, it also prepared states like Oregon for a growing national and international export market. An unnamed commentator in the state's largest newspaper, The Oregonian, remarked on the state of agriculture in 1888:

Among the most prosperous farmers in all the world to-day are those of Oregon. This of itself is sufficient evidence as to what Oregon is capable of as an agricultural region. And yet the agriculture of the state as well as all its other resources is in a very primitive state of development. The

\footnotetext{
management. This approach enlisted colleges, scientists, and trained experts to increase and standardize the nation's agricultural output. Federal officials justified this by citing the poor conservation practices that had destroyed much of the forests and farmland on the East Coast. They were also encouraged by the world's technological developments, which brought global trade closer, increasing capitalistic competition and a need for a stronger economy. ${ }^{28}$ Steven Stoll, Larding the Lean Earth: Soil and Society in Nineteenth-Century America.

${ }^{29}$ Johansen, Empire of the Columbia a History of the Pacific Northwest, 282-283.

30 Schwantes, The Pacific Northwest: an interpretive history, 171.

31 Johansen, Empire of the Columbia a History of the Pacific Northwest, 318.
} 
next five years will double its acreage under cultivation and will increase in almost an equal proportion the development of other resources. ${ }^{32}$

Using the age old established trade lines of the state, Portland continued to be the market for its hinterland of wheat, sheep, cattle, timber and other commodities. Industrial enterprise in timber, farming, manufacturing, and mining expanded exponentially between 1880 and 1890, moving through Portland to the rest of the world. In 1890, "Portland's rail shipments to the sound amounted to $\$ 750,000$, coastwise trade to nearly $\$ 5,000,000$, and foreign export trade to $\$ 6,600,000,80$ percent of it wheat and flour." 33 By 1903 , products exported to Asia and Oceana reached $\$ 10,000,000$ and accounted for a third of the local export. ${ }^{34}$ This astronomical growth in trade illustrates the significance of Portland's different market layers in relation to each other: local, national, and international trade. Farm produce from the hinterland gave Portland the economic capacity to connect internationally.

None of these new commercial connections and relationships were possible without a steady flow of labor and capital. Between 1860 and 1890 Oregon's population as a whole bounded from 52,465 to 317,704. As it became the state's commercial center, Portland saw much more dramatic population increases and swelled from 2,874 in 1860 to 46,385 in 1890 . Two decades later, after several expansions and municipal additions, Portland's population accounted for almost a third of the entire state's total. ${ }^{35}$ By the beginning of the twentieth century, the city's role as Oregon's commercial metropolis had been all together confirmed. The web of urban and rural relationships that stretched out from Portland and dictated the

\footnotetext{
32 “Opinion," Oregonian, October 28, 1888.

33 Johansen, Empire of the Columbia a History of the Pacific Northwest, 330.

${ }^{34}$ Lisa Blee, "Completing Lewis and Clark's Westward March: Exhibiting a History of Empire at the 1905

Portland World's Fair," Oregon Historical Quarterly 106, no. 2 (July 1, 2005): 250.

35 US Bureau of Census, "Urban and Rural Population: 1900 to 1990," Washington, DC: Government Printing Office, October, 1995.

http://www.census.gov/population/www/censusdata/files/urpop0090.txt; and "Population of the 100 Largest Urban Places,” Washington, DC: Government Printing Office, June, 1998.

http://www.census.gov/population/www/documentation/twps0027/tab12.txt. Accessed on January 25, 2013.
} 
state's flow of commerce would take over a century of technological developments to even begin unraveling. While these developments are important to understanding how the state worked economically, they are also central to realizing the ideology of a commercial structure to which people in urban and rural settings actively adhered. Portland became a place for political and social change, and the destination for those battles to play out. At the turn of the century, the city had grown beyond being a geographical center and had become the economic and cultural leader for the state.

On June 1, 1905, Portland advertised its confirmed role in the state with the opening of the Lewis and Clark Exposition. ${ }^{36}$ Modeled after Chicago's World Columbian Exposition, the intentions were exactly the same: promote the city economically and socially, and make the case for new capital investment. Not surprisingly, the exposition was hardly just an endorsement of Portland, but rather symbolized the city's hinterland empire and the commercial capacity that flowed through it. Exhibits like the Palace of Agriculture and the Forestry Building were emblems of the wealth that farms and forests brought to the city. ${ }^{37}$ To visitors, there was no fruit, vegetable, or grain that Oregon's farmland could not grow. The Exposition also illustrated the city's role as a powerful port and vital connection to markets in the Far East with the Oriental Building, the sole purpose of which was to display a history of Northwestern trade to Asia. The fair was the ultimate display of boosterism and emphasized Portland's role as Oregon's metropolis. ${ }^{38}$

\footnotetext{
${ }^{36}$ Carl Abbott, Portland in Three Centuries: The Place and the People, 71-75.

${ }^{37}$ Blee, "Completing Lewis and Clark's Westward March: Exhibiting a History of Empire at the 1905 Portland World's Fair," 250.

38 Blee, "Completing Lewis and Clark's Westward March: Exhibiting a History of Empire at the 1905 Portland World's Fair,” 251-252.
} 
The Lewis and Clark Exposition represented the relationship between the region's urban and rural environments. The implications of this association produced complex political, social, and cultural reactions. In the decades leading up to the beginning of the twentieth century, Oregon's citizens adjusted and attempted to regulate the new diffusions of power wrought by expansions in wealth and commercial power. The people of Oregon, as well as the rest of the country, reacted to the societal changes in a variety of ways. Their reactions, particularly through political movements, shaped the way in which many Americans valued economic, social, and political relationships. Not ten years after the exposition, the Carroll Public Market became a celebration of these new ideologies and was fiercely protected by those who valued it.

The Places of Power: Populists to Progressives

Following the Civil War, new degrees of hierarchal power, greater reliance on the efficiency of scientific management, and the intensification of bureaucratic organization permanently propelled the United States out of a decentralized agrarian state and into a modernizing industrial powerhouse. These new systems of commerce created unimaginable wealth for some and desperate poverty for many others, changing the way urban and rural environments interacted. In places like Portland, this happened at a comparatively smaller scale than in some of the larger Midwestern cities like Chicago. Nevertheless, producers and consumers in Portland had to deal with new ways of commerce.

Politically, these changes spurred the Populist Movement of the late nineteenth century and the Progressive Movement of the early twentieth century. The ideology of 
populism primarily emerged out of groups of organized farmers that had become unsatisfied with the new structure of business. ${ }^{39}$ As the People's or Populist Party, organized in 1892, their main objectives were to give more economic and political power to farmers by restructuring the way the economy worked through initiatives like a graduated income tax, government control of communication and transportation, and direct election of U.S. Senators. The idea was not to promote government as the solution to capitalism but rather to use it to eliminate speculative commercial waste. The movement believed that management of certain commercial and social institutions could reduce economic disparity for America's most productive occupations. The Progressive Movement mostly focused on urban environmental reform (city health and sanitation) and labor conditions but found common ground with Populists on some issues like labor, the elective process, and social inequality. ${ }^{40}$ According to historian Robert Johnston, Portland's middle class progressives allied themselves with working class and labor union ideals in ways that greatly illuminated "the continuities between nineteenth- and twentieth-century political economy," particularly when it came to support of the petty or individual producer. ${ }^{41}$ The main point of agreement for both movements was a belief that government could be an institution for debating and enacting change. Between 1880 and 1930, both groups actively sought to do so; helping to permanently change the definition of government for Americans and their political parties. Nationally, historians have disagreed on the continuity of these movements, but in Oregon the transition was arguably more cooperative. ${ }^{42}$ Not unlike the role rural environments

\footnotetext{
${ }^{39}$ Charles Postel, The Populist Vision (New York: Oxford University Press, 2009); and Oscar Winther. The Great Northwest: A History 2nd ed. (New York: Knopf, 1950), 315-316.

40 Winther, 320-322.

${ }^{41}$ Johnston, The Radical Middle Class, 75.

42 To be clear, Populists' political power in Oregon was decidedly weaker than Progressives after 1900. So while Oregon may have experienced a longer duration of populist influence in the political, social, and economic
} 
played in fueling the centralization of commercial activity in Portland, rural populism carried through into the Progressive Movement, fueling and influencing its ideological objectives.

The consolidation of wealth produced technological and market advantages for large landholders against smaller ones. Being composed of mostly smaller family farms, Oregon's farmers experienced a great deal of economic hardship. The reason for the disparities though, were infinitely more complex and as a result, many farmers pointed to the most visible people they considered to be the source of the problem: "the middlemen." Generally speaking, middlemen occupied every traded exchange that products made in between producers and consumers. This included but was not limited to merchants, railroads, investors, bankers, and storage operators. Frustration and anger towards middlemen fueled farmers to seek political power throughout the last half of the nineteenth century.

The earliest organizations for farmers in Oregon were created in 1853. More formal groups like the Oregon State Agricultural Society and the Farmers' Union were developed in 1860. ${ }^{43}$ These assemblies occasionally worked politically, but were primarily interested in cooperative economic power such as owning their own warehouses, grain elevators, and riverboats. In 1873, the National Grange of the Order of the Patrons of Husbandry (commonly known as the Grange) reached Marshfield, Oregon. This was the state's first nationally organized association for farmers and within two years, there were 177 granges across the state. ${ }^{44}$ The Grange was designed to act as a persuasive lobby and educational resource for farmers, taking care to stay non-partisan. While the movement as a national

spheres, its enthusiasts did not enjoy the same degree of clout that progressives did during the beginning of the twentieth century. Johansen, Empire of the Columbia a History of the Pacific Northwest, 456-457; and Johnston, The Radical Middle Class, 75 and 122-123.

43 Winther, 312-313.

44 Thomas C. McClintock, "Seth Lewelling, William S. U'Ren and the Birth of the Oregon Progressive Movement." Oregon Historical Quarterly Vol. 68, No. 3 (September, 1967), 200. 
force succeeded in the legitimizing of public regulation of railroads and grain elevators, and played a major role in the creation of the Farm Credit System (1916), the group's political clout only lasted through its initial decade. After 1880, the national Grange movement saw significant decline in membership. Yet this was not true in Oregon or the Northwest, where memberships actually continued to grow.

Other agrarian groups like the Farmers Alliance gained significant membership in Oregon after 1890. Rather than emphasizing cooperative solutions, the Oregon Alliance focused on gaining tangible reforms that could provide economic relief. Their work ultimately "provided the grass roots organization and political support necessary for third party political action through the People’s Party." ${ }^{45}$ While Populism's as a political party declined after its loss and ideological fracturing during the national election of 1896, Oregon Populists won big.

The reasons for Oregon's dedication to populist ideology during a time of waning populist support across the country are complex but its economic-geographical history offers some possibilities. For one, the web of commerce out of Portland experienced a general economic isolation longer and deeper than many other major cities outside the Northwest. Second, the city of Portland was comparatively smaller than many other metropolitan centers of that time. Even in 1900, farmland still existed within the city limits

\footnotetext{
45 On the national level, Populism, as a political movement, came to a head with the election of 1896 when William Jennings Bryan first ran to become the next president. Desiring to attack Republican interests and institutions like the railroads, many believed that Bryan was the best candidate for widespread voter appeal among Democrats and Populists. Unfortunately, the adolescent People's Party was divided in its support for Bryan or cross-party alliances. Eventually, the effects of the cross-party collaboration were largely unsuccessful and issues over race and "free silver" often got in the way of sustainable support. After Bryan's loss, Populism as a national political movement rapidly deflated. Bernard Falk, Populist Progressivism: Popular Democracy in Oregon, 1892-1910 (Reed College: Portland, Or., 2004), 33-34.
} 
and the economy was largely supported by the products of the agricultural hinterland. ${ }^{46}$ This economic-geographic isolation and system may have played an important role in sustaining cultural bonds between urban and rural environments that otherwise would have been lost as Portland connected itself further with markets and capital outside the region. The real answer is most likely more complex, but the fact remains that Portland, unlike many other metropolises of its time, continued a tradition of populism well past the national decline.

Political leaders like William Simon U'Ren illustrate the character of populistprogressive politics in Oregon at the turn of the twentieth century. During the 1890s, U'Ren played a pivotal role in the development of the Direct Legislation League, a populist advocacy group for the establishment of an initiative and referendum system in Oregon, which allowed for direct legislation by citizens. As secretary, he was able to bring together interests from the Oregon Farmers' Alliance, the Grange, the Oregon Knights of Labor, and the Portland Federated Trades Union. ${ }^{47}$ Passing the Initiative and Referendum Amendment took almost a decade but was eventually successful as populists like U'Ren found common ground and rational compromise with Portland's progressives. The Amendment was ratified in Oregon in 1902, giving Oregon's citizens greater control over their legislative democracy. ${ }^{48}$ From collaborations like this, populism ideologically remained viable in Portland and Oregon, and continued through the Progressive movement of the early twentieth century.

46 Abbott, Portland in Three Centuries: The Place and the People, 82-85.

${ }^{47}$ Falk, Populist progressivism: popular democracy in Oregon, 39-41.

${ }^{48}$ Falk, Populist progressivism: popular democracy in Oregon, 71-72. 
As a direct result of the Initiative and Referendum Amendment, Portland's citizens voted to adopt a commission form of government in May $1913 .{ }^{49}$ The commission replaced the larger part-time council with four full-time commissioners, each in charge of a different department. The new government also dissolved party affiliation, making city politics a matter of personalities rather than partisanship. ${ }^{50}$ This change gave the mayor and the commission legislative equality by eliminating the mayor's veto, although some members of the business community subsequently argued that this caused the government to run less efficiently.

The Oregon System was likely the most significant expression of the state's lasting populist appeal. Its instatement opened the doors for other measures between 1910 and 1930, most notably the campaign for the Single Tax. While the Oregon System sought to give more political power to the individual voter, the Single Tax addressed economic disparities and intended to restore power to the individual producer. The proposal targeted wealthy land investors in cities and resource extractors in rural environments with an “effective $100 \%$ capital gains tax on increases in land value." It was named the "single tax" because it was believed that it would eliminate the need for many other taxes that made things more difficult for small producers. ${ }^{51}$ The "single tax" was developed by Henry George, a late nineteenth century American philosopher of economics who believed the government should secure all appropriations of "unearned increases in land value." 52 The burden was to fall primarily on wealthier Americans in the interest of encouraging a more

${ }^{49}$ Currently, Portland is the only major American city to still have a commission form of government. MacColl, The Shaping of a City, 441-445.

${ }^{50}$ MacColl, The Growth of a City, 14.

51 Johnston, The Radical Middle Class: Populist Democracy and the Question of Capitalism in Progressive Era Portland, Oregon.

52 Robert D. Johnston, “The Single Tax." The Oregon Encyclopedia. Oregon Historical Society. http://www.oregonencyclopedia.org/entry/view/single_tax/ (accessed on January 25, 2013). 
productive and efficient system of development. Farmers might have benefitted greatly from this, but also poorer urban dwellers. While Oregon's Grange never officially embraced the Single Tax, some members identified with the proposal to address income and economic inequalities. ${ }^{53}$

Between 1908 and 1920, populists and progressives gained significant support for the measure under the banner of the Oregon Tax Reform Association. U'Ren was a primary advocate, and was again a major force and connective piece between populists and progressives. In 1910, the group organized to enact an amendment that would eliminate the poll tax; a piece of legislation they believed would act as a stepping stone to the single tax. The measure passed narrowly across Oregon, with Portland sturdily showing its populist support. ${ }^{54}$ From 1912 until 1922, the single tax was placed on the ballot again and again with statewide support diminishing over the years. Yet Portland remained dedicated to the proposal; in each election at least one out of every four votes in the city was a favorable one. In 1914, they convinced majorities in many neighborhoods.

Experiences of cooperation allowed the values of populism to continue much longer in Portland than on the national scene. The ideological relationship also encouraged a robust Progressive tradition in the city. Events like the Lewis and Clark Exposition highlighted the extent to which urban and rural dwellers had become economically and culturally intertwined. During and after the Exposition, the city experienced an incredible population

\footnotetext{
53 The benefits were clearer for urban dwellers that experienced wealthy investors' speculation of land values on a regular basis. It is unclear as to exactly how the legislation may have played out, but it can be certain that individual farmers would have experienced a lesser tax burden. The measure would have had profound implications on the size of farms as well; making it more profitable to operate at smaller or more efficient levels that were not burdened by varying layers labor and management. In the end, farmers may have been uneasy about the system because it was so radically different from other states and what had been done in the past. "Single Tax Discussed," The Oregonian, March 21, 1912.

54 Johnston, The Radical Middle Class, 163-176.
} 
increase; between 1900 and 1910 its population more than doubled from 90,426 to $207,214 .^{55}$

Progressive groups like the Commercial Club of Portland were one of the most prominent booster organizations during the early decades of the twentieth century. Their mix of commercial advocacy and civic pride made them accessible and fairly influential. With roughly one thousand members, the club was composed of prominent businessmen, leaders, and figureheads from all over the state. While its members were particularly active in Portland, they also advocated for growth and development statewide. As the population and the boundaries of the city expanded, progressives and boosters from groups like the Commercial Club and the Civic Improvement League initiated countless developments such as the doubling of city park acreage, public markets, taller buildings, comprehensive public transportation, and an expansion of other public buildings and services. ${ }^{56}$ This period of heightened progressivism in the city celebrated the maturation of Portland and the possibilities that lay before it.

Progressivism was certainly not unique to Portland or Oregon. Nationally, the movement gained substantial ground from the nation's growing middle class and civicminded elites during the early twentieth century. Subscribers sought to clean up the wastes of industrial capitalism and restore the health of cities. Portland's City Beautiful Movement and creation of the Rose Parade were some of the many symbols its citizens created to express their newfound civic involvement and belief in public institutions. Other

\footnotetext{
55 US Bureau of Census, “Urban and Rural Population: 1900 to 1990,” Washington, DC: Government Printing Office, October, 1995.

http://www.census.gov/population/www/censusdata/files/urpop0090.txt; and "Population of the 100 Largest Urban Places,” Washington, DC: Government Printing Office, June, 1998. http://www.census.gov/population/www/documentation/twps0027/tab12.txt. Accessed on January 25, 2013. 56 Carl Abbott, Portland: Planning Politics and Growth in a Twentieth-Century City.
} 
developments like the Oregon System and the Single Tax Movement illustrate the decidedly populist tones of progressive reform throughout the state. Of Oregon's rural, urban, populist, and progressive communities, contempt could be collectively formed and targeted at the non-producer (middleman, speculator, etc.) while support was reserved for the individual producer. Historians like Larry Lipin have shown that this framework of values often became muddled depending on the issue(s) at hand; the construction of the Columbia Gorge Scenic Highway pitted Oregon's producerist working class against “conservationist" minded progressives. ${ }^{57}$ In the case of the public market in 1914, value could be found throughout varieties of groups, because it was such a clear battle between the producer and the non-producer. Political cooperation and ideological similarities throughout the turn of the century, confirmed this fusion of populist and progressive sentiments.

Between 1870 and 1920, Portland and its agricultural hinterland were finding common ground and forged connections in political and institutional campaigns. With the development of Portland's commercial web to Oregon's prominent farmland, and the cooperation between rural Populists and urban Progressives, municipal markets began to gain wide appeal. For supporters, these markets promoted a moral economy and a vision of rural producers united with urban consumers. By 1920, every major city in Oregon had a public market, but none of them were as celebrated or renowned as Portland's. The Carroll Public Market would prove to be a culturally-political symbol for the common aspirations of rural producers and urban consumers.

“Need for a Market:” Producers to Consumers

${ }^{57}$ Larry Lipin, Workers and the Wild: Conservation, Consumerism, and Labor in Oregon, 1910-30 (Chicago: University of Illinois Press, 2007). 
Public markets were essential to most towns and cities before the Civil War. Their role in civic life, though, was not determined by political or cultural ideology. Simply put, they were the only avenues of food distribution. Following the end of the Civil War though, private enterprise was encouraged to open up and take over the reins of food distribution. ${ }^{58}$ In the first decades of Portland's evolution, farmers were so close to population centers that most of the city's food supply was provided by local family farms and peddlers. As Portland grew into a centralizing commercial force of the state, however, the strains of greater population called for produce from well outside the city limits and more complex distribution systems. Between 1851 and 1914, Portland had a variety of institutions for grocery, from privately owned public markets, to city blocks designated for sale of produce, to grocery stores, to communally organized farmers' markets. Not until the organization of the Carroll Market did Portland attempt to manage the distribution of food. After decades of metropolitan growth in the city during the nineteenth century, the physical and political divisions between rural and urban peoples had become distinct. The public market could shed those differences under a cooperative goal. The campaign for the Carroll Market brought together a diverse set of people that found political and cultural value in it and ultimately, the development of this community established a massive historical foundation, giving the market a unique place in the minds of producers and consumers.

\footnotetext{
58 Throughout American history, markets have been notoriously powerful places for the dissemination of culture, politics, environmental influence, commerce, and social attitudes. Until the mid-nineteenth century, markets were not only physically central but commercially central to urban spaces. Negotiations here could change what happened on farmland miles away or determine economic hierarchies within the city. Social interaction here played a vital role in the propagation of cultural, racial, gendered, or political opinion. Tangires, Public Markets and Civil Culture in Nineteenth Century America, 118-119
} 
During Portland's formative years, the days of city-owned public markets were fading quickly across the nation. The sheer size of many nineteenth century cities was enough to dissolve the central role of public markets but in a small municipality like Portland, the need for a permanent centralized market institution seemed apparent. As early as 1853 , the city's proprietors had set aside a space of land in the southwest quadrant near Fifth and Morrison with the intention of creating a public market. ${ }^{59}$ After almost twenty years of scattered and various market systems, about one hundred of Portland citizens presented the city council with a petition in 1866 "praying for the erection of a City Market, and representing that the convenience, to be under the control and direction of the corporate authorities of the city." ${ }^{60}$ Nevertheless, the council failed to respond to the petition, deciding instead to erect Portland's customs house on the southwest corner of Fifth and Morrison. The decision created a gap in the city's desired commercial structure.

Captain Alexander P. Ankeny was one of the first citizens of Portland to focus his efforts on the creation of a market for producers and consumers. Ankeny, a former sea captain and butcher arrived in 1850, a year before the city's incorporation, and within a decade, bought up a block of land (called the Ankeny Block) "bounded by Ash and A (Now Ankeny), First and Second" in what is today considered the heart of "Old Town." ${ }^{61}$ As a farmer, entrepreneur, and investor, Ankeny was able to identify the needs of Portland's growing urban and rural populations. He had also built his first business career around public markets in places like Wheeling, West Virginia, and other towns along the Mississippi

\footnotetext{
59 Eigo, A Market for the City: The History of Portland's Public Market, 2.

${ }^{60}$ Edited by David Powers, Ankeny's New Market and Theater, Portland: Oregon Historical Society, 1976, Call Number: OVERSIZE 979.111 N5561 1976, 2.

${ }^{61}$ Construction began on September 1, 1872 but after discovering foundational problems with the soil, the site was moved a short distance in January of 1873. Ed. Powers, Ankeny's New Market and Theater, 3-4.
} 
and Ohio rivers. Aware of the success of public markets in San Francisco, Ankeny decided by 1871 to create one massive Victorian style brick building for use as a public market and a theater. Both roles of the building helped transform Portland from a small town to a metropolitan destination. Yet the market's function as a capitalistic endeavor elicited some skepticisms as in an Oregonian editorial expressing only tentative support for the idea in 1872:

Such a place will soon become a sort of headquarters for the numerous producers of all variety of provisions in our vicinity, who are now in the habit of either peddling the products of their farms, gardens, or dairies on the street, or selling them to groceryman through whose hands will pass to the consumer. The establishment of a public market will afford facilities for the buyer and the seller to meet and make their exchanges without the intervention of third parties. And thus secure mutual advantages... Business tact, however, seeing that such enterprises are not failures elsewhere, and that the chances of success are favorable, has suggested to one of our citizen capitalists the plan of undertaking this needed improvement on his own responsibility. What measure of profit shall accrue to Captain Ankeny in this enterprise... ${ }^{62}$

The New Market and Theater (also known as the Central Market) officially opened

October 5, 1872. Fitted with chandeliers, Corinthian columns, archways, a twenty foot ceiling, and a rich red brick façade, the three story building certainly contrasted with the growing Portland. It was designed like any marketing orientated business, in an attractive and alluring way with modern technologies like gas lights and an elevated colorful flower centerpiece. ${ }^{63}$ With only twenty-eight stalls, the market was considerably smaller than Portland's later public markets. While it is unclear as to what the exact regulatory design of New Market and Theater was, it is known that it operated more as a centralized competitive environment than a strict municipal market. Stall renters could expand their vending space by buying out the lots of those near them. They could also make their own improvements to the stalls, which contributed to the level of competition among vendors. The largest business operation came from meat packers like A.H. Johnson and the Spaulding brothers. These

${ }^{62}$ Editorial, Oregonian, April 28, 1872.

${ }^{63}$ Goods at the market varied widely and unlike the Carroll Market, non-agricultural produce items like meat, fish, game, poultry, coffee, liquor, bread, and dairy were all sold. Ed. Powers, Ankeny's New Market and Theater, 5 . 
vendors butchered meat from farms as far away as Walla Walla and also ran a sizable wholesale business on the side, potentially even supplying some of their competitors. ${ }^{64}$ In essence, the market building was managed more like a modern mall than a traditional producer-to-consumer municipal market. Nonetheless, it was a central force of cultural and economic activity in Portland and satisfied the city's consumers while it was alive.

The theater was not completed until 1875 but it quickly became a main attraction in Portland. By that time, a fountain had been added to the center of the facility where a concert was regularly preformed outside on Saturday nights. ${ }^{65}$ Ankeny’s New Market and Theater showcased the nation's newfound technological modernity as well as celebrating Portland's transition into the state's metropolis as both a point of cultural gravity and inspiration for the city's potential. To some degree, the market also promoted the direct experience of community between rural producers and urban consumers that had begun to fade as the city grew. Both the market and the theater remained operational until 1887, when it closed as a result of pressure from urban growth and the westward drift of the city center away from its location. ${ }^{66}$

For the next decade, other businessmen tried their hand at running small-scale public markets, but none of them experienced anything close to the fifteen years of success that Ankeny's had. The records of these markets are extremely scarce and even the most notable, the Metropolitan Market, appears to have lasted less than five years. ${ }^{67}$ In 1892 , the Oregonian even reported that producers were haphazardly selling along Madison Street rather than the

\footnotetext{
${ }^{64}$ Ed. Powers, Ankeny's New Market and Theater, 7.

${ }^{65}$ Ed. Powers, Ankeny's New Market and Theater, 6.

${ }^{66}$ Designed by Jeff Fisher, “The New Market Colonnade Reconstruction,” Public Market Folders, Oregon Historical Society, Portland, OR, 2.

${ }^{67}$ Eigo, A Market for the City: The History of Portland's Public Market, 7.
} 
small public market out of convenience. According to the newspaper, the self-governing vendors of the market blocks were practically unable to sell directly to consumers, "It is not worth a private individual's while to attempt to make a purchase; he is referred to the grocery stores or the peddlers." ${ }^{68}$ In the final years of the nineteenth century however, momentum began to build for a new public market, as food prices and political uproar highlighted the costs of the middleman. This time, farmers, political groups, business organizations, and social clubs rallied to the idea.

Support for a public market was also encouraged by the fact that food distribution in Portland and in many other American cities during the late nineteenth and early twentieth century had become problematic. The immense size of these ever expanding metropolises made farm direct produce increasingly harder to obtain. In a city like Chicago, which was well over ten times the population of Portland in 1900, obtaining food that had passed through many "middlemen" was expected. ${ }^{69}$ This increased prices dramatically and further complicated the growing social and economic rift between rural and urban populations. Regardless of the metropolitan size, Portland was still the commercial center of Oregon and thus its business created demand that rural producers were subject to. The development of different urban and rural political identities came from the way in which nineteenth century American cities' economies evolved. ${ }^{70}$ The incredible concentration of trade consequently permitted the expansion of "the middleman's" role.

\footnotetext{
68 “A Busy Market Place,” The Oregonian, June 6, 1892.

${ }^{69}$ Deutsch, Building a Housewife's Paradise: Gender, Politics, and American Grocery Stores in the Twentieth Century.

${ }^{70}$ William Cronon has illustrated that many people believed the greatest contrast between city and countryside lay in vice. Rural peoples understood that the city concentrated trade of all forms including sin. It was this concentration that many believed exacerbated corruption and unnecessary economic inefficiency that always laid the cost with the producer. This skepticism of their urban counterpart was far from unfounded and it comes as no surprise that populist farmers pushed for an economic system that favored those who actually produced. Cronon, Nature's Metropolis, 266-267 and 357-358.
} 
In Portland, many produce peddlers were immigrants (mostly Chinese and Italian) who grew their fruits and vegetables from residential plots within the city limits. The steep gorge of Tanner's Gulch, immediately west of Portland's choicer commercial and residential areas roughly bounded within Fourteenth and Twenty First streets, and by Burnside and Market, featured large series of vegetable gardens that Chinese families and peddlers managed from their residential properties. ${ }^{71}$ The Chinese operated out of this site from approximately 1879 until 1910, when they were eventually forced out by commercial growth, urban expansion, and nativist sentiment. ${ }^{72}$

For some Portlanders, anti-middlemen sentiments meshed effortlessly with racist notions of immigrant populations, making Chinese peddlers an easy political and social target. Peddlers were often considered middlemen because they sold a variety of goods; in the Department of Commerce's 1918 report, Municipal Markets in Cities Having a Population of Over 30,000, all records of peddler and huckster licenses were classified as "nonproducers.,"73 In the case of Portland, Chinese peddlers consisted both of merchants living along the river and farmers in the Gulch. In 1910, as anti-middleman sentiments were growing and the public market campaign was seemingly close to a permanent institution, the city outlawed all peddling in the downtown. ${ }^{74}$ The ordinance ended the Chinese Garden Community and

\footnotetext{
${ }^{71}$ Prior to 1873, Tanner's Gulch was subject to frequent, uncontrollable flooding. In 1873, an old wooden bridge that spanned the gulch broke after heavy rains. The replacement crossway required a stone culvert beneath the structure for better support. According to Wong, the culvert "provide[d] drainage" and "made it possible to control, if not totally prevent, flooding of the creek." Following this event, many Chinese families established residences throughout the gulch and used the fertile soil for farming. Marie Rose Wong, Sweet Cakes, Long Journey (Seattle: University of Washington Press, 2005), 206.

${ }_{72}$ Wong, Sweet Cakes, Long Journey, 210-220.

${ }^{73}$ U. S. Bureau of Census, "Municipal Markets in Cities Having A Population of Over 30,000: 1918," Prepared by Sam L. Rogers, Washington, DC: Government Printing Office, 1919.

${ }^{74}$ Wong, Sweet Cakes, Long Journey, 219 and 220.
} 
allowed the Multnomah Amateur Athletic Club to buy up the land, suggesting that sentiment against peddling was also motivated by a sense of legitimacy.

Rural spaces like Tanner's Gulch with close proximity to the commercial downtown prevented the animosity toward middlemen that prevailed in other larger cities during the late nineteenth century. Surprisingly, however, the issue of middlemen still gained attention in Portland through the group networks of populists and progressives. Anti-middlemen sentiments gained substantial support after 1910, coinciding with the decline of the Chinese Garden Community and the outlawing of peddling. On the first of the year in 1898, T. T. Geer, a farmer from Macleay, Oregon, submitted a piece to the Oregonian in which he stated that, “...the first thing a farmer wants is a market for his produce. A home market is the best there is...Every time he has anything to sell he trots off to town with it to find a purchaser, which, it would seem, that one of our pressing needs is more and larger towns." ${ }^{75}$ Farmers like Geer believed in the developing urban and rural relationship and saw it as a bond in which the two places could "grow up together." This rhetoric prevailed as support for a new public market emerged. Later that year, P. W. Gillette, a resident of Portland, expressed concern over the condition of food distribution in the city stating: "There is nothing that Portland needs so much, and that would give such positive and immediate benefit to her people as a commodious market house...All classes high and low, rich and poor go to the market...Let the city provide market places where the consumer can get...direct from the producer, that they no longer be compelled to support a gang of middlemen." ${ }^{, 76}$ Gillette asserted that the failure of the New Market and Theater was due to its efforts for "revenue and profit." Both Geer and Gillette, like many rural and urban dwellers of the region,

75 T. T. Geer, "Oregon Farm Life," The Oregonian, January 1, 1898.

76 P. W. Gillette, "Public Market Places." The Oregonian, August 21, 1898. 
believed that public markets bolstered the well-being of the city as places for wholesome food and local economy.

The lack of a permanent market bothered producers and consumers alike.

Throughout the first decade of the twentieth century, Portland's avenues of food distribution resembled its formative years; small-scale grocers, community markets like the Italian Rancher's and Grower's Association (IRGA), peddlers, and local farmers with wagons clustered in various sections of town. ${ }^{77}$ The scene certainly did not resemble the prosperity, elegance, and managed organization that Ankeny's market had. Adding to the frustration, debate had begun to build over the future of city blocks southwest of Portland's downtown. The Market Block, located between Second and Third, and Clay and Market streets, had been donated in 1851 by Colonel W. W. Chapman for farmers to use as a market space. Until 1902, the block was never once used for space as a public market and at the time had one old, barely used building that had been a part of Portland's Mechanic's Fair. Following 1900, organized support increased dramatically as debate over the fate of the old Market Block began to intensify. Chapman's heirs contested the lack of a market on the grounds and at one point threatened to reclaim the land for its original purpose. To resolve the issue, the city of Portland paid the heirs $\$ 1200$ for the property. ${ }^{78}$

Agrarian organizations produced some of the first formalized challenges to the city's lack of a public market. Between 1898 and 1902, grange members from groups like the Evening Star Grange advocated for a new public market in Portland, believing that the Market Block was the rightful and best location. ${ }^{79}$ They also alleged that the market worked

\footnotetext{
${ }^{77}$ Eigo, A Market for the City: The History of Portland's Public Market, 9.

78 "Plan for Public Market," The Oregonian, April 3, 1902.

79 "For a City Market Place," The Oregonian, March 20, 1902.
} 
best as a public institution that could be free of middlemen to be purely for the benefit of producers and consumers. The intensity of the debate escalated in March 1902 when the Union Market Company, a private corporation, declared that it had intentions of purchasing the block and converting them into a public market that could eventually be bought and run by the city. ${ }^{80}$

Support for a new producer-to-consumer market was widespread, although many disagreed as to whether it should be private or public. In April 1902, A. J. Johnson spoke on behalf of farmers for Multnomah, Clackamas, and Washington counties, "condemning private ownership" of the market. Farmers and Grange members alike agreed that the best interest of producers and consumers could only be satisfied with a municipally owned market. In their eyes, a public market should not seek out profit, and if additional revenue beyond operating costs was gained, it could be used for the betterment of the city and its people. In the end, the city council agreed with the Union Market Company in 1903 and offered them a ten-year lease to create a market on the Market Block. With the matter of the Market Block resolved, the Grange's campaign began to dissipate. During the next five years moreover, the Union Market Company's building became the subject of multiple health violations, forcing it to transfer ownership to the People's Market Company. In the beginning of 1908, the city council stated that the provisions of the agreement had not been met and they revoked the franchise, shutting down the market.

Over the next six years, other privately owned public markets were opened throughout the city. These operations were similar to the other private markets only in the fact that they were designed more like malls, and sold a variety of produced goods in which

80 "Plan for Public Market," The Oregonian, April 3, 1902. 
it was not always clear whether goods were from a single producer or the local region.

Private ownership was a point of conflict for those who believed in a municipally owned public market and despite several private markets sprouting up, support began to build again for a new municipally owned market.

In 1911, Portland and Gresham’s Commercial Clubs and Progressive Businessmen Clubs started meeting to discuss the benefits of a city-owned market. ${ }^{81}$ Not unlike the farmers and Grange members that had boosted the idea for the previous fifty years, these progressive clubs believed in the value of a market that was void of the middleman. For populist farmers and progressive consumers, the pursuit of profit had made food more expensive than it should be and the commercial chain it needed to pass through before reaching the consumer had only degraded the quality of food. Throughout the year, the groups presented their campaign in front of the Evening Star, Lents, Woodlawn, Russellville, Fairview, Corbett, Sycamore, and Rockwood Granges and encouraged them to discuss the issue with non-member farmers. Housewives were central to the purchase of food during this period, and women's groups like the Consumer's League also advocated in favor of the new municipal market. By October 1911, the supporters had compiled information on eastern states' public markets and organized a conference with delegates from various interests. Portland's city council even sent over delegates, including the future mayor, George Luis Baker, to hear the proceedings. ${ }^{82}$ Baker was one of Portland's most memorable mayors. Considered by many to be a gregarious and generous man, Baker served as mayor of Portland from 1917 until 1933. He regularly positioned himself in the politics of the public market over his sixteen years in office. Initially, Baker was a staunch advocate of the Carroll

81 "Move For Public Markets Endorsed," The Oregonian, October 11, 1911.

82 "Move For Public Markets Endorsed," Oregonian. October 11, 1911. 
Public Market but by the second half of the 1920s he was in full support of its replacement, the Portland Public Market.

Within a month of the public market conference, the city council had formed its own special committee, with Baker as chairman, to discuss the possibility of creating an "AntiMiddleman System." ${ }^{\prime 83}$ Following the initial meeting, the committee confirmed with city attorneys the legality of a publically owned market, and in the first month of 1912 approved plans with the city council to build a municipally owned market. ${ }^{84}$ Over the course of the year, the council fumbled with the debate over financing and locating the project. Speculation of the market's cost varied widely from thousands of dollars to hundreds of thousands of dollars and no one was ever really sure where to locate it. In November, the resolution was voted down by the city council, amid concerns over the cost and location of the city's new publically-owned auditorium. ${ }^{85}$ The auditorium, not unlike the public market, was considered a much needed institution by some of Portland's citizens. Between 1911 and 1914, the two projects competed for voters' attention and the financial approval of the city council. In the end, the auditorium plan won the Market Block as its future site. Three years later in 1917, the Portland Municipal Auditorium opened. ${ }^{86}$

As a result of tension over competition from the public auditorium, the new city commission passed an emergency declaration on May 14, 1913, allowing farmers to sell their goods off the curbs of Lownsdale and Chapman Squares, informally known as the Plaza, which consisted of two blocks bounded by Madison and Salmon, and Third and Fourth streets. In response, The Oregonian declared that, "The barrier that has intervened between

\footnotetext{
83 "Plan Made For Public Markets," The Oregonian, November 28, 1911.

84 "Market Bonds Favored," The Oregonian, January 28, 1912.

85 "City Rejects All Bonding Measures," The Oregonian, November 4, 1912.

86 The auditorium still exists today as the Keller Auditorium. MacColl, The Shaping of a City, 452-453.
} 
one class of producers and the consumer was demolished yesterday..." ${ }^{, 87}$ Still not satisfied, public market supporters like Baker and sympathetic organizations reinvigorated their campaign throughout 1913, as more of Portland's citizens began to involve themselves in the cause.

John F. Carroll was one of the central figures in the campaign. An active member of the Commercial Club and one of the primary promoters of the Portland Rose Festival, Carroll began to aggressively advocate Portland's need for a public market in the editorial section of his The Evening Telegram in $1914{ }^{88}$ Carroll declared that a public market could provide three important benefits: first, it could attract a larger farm population with fairer prices and solve the "problem of unoccupied lands;" second, it would "eliminate the middleman" and lower prices food prices for urbanites; and third, Portland could compete with other cities in the Northwest that already had public markets like Seattle, San Francisco, and Vancouver. ${ }^{89}$ Carroll's rhetoric was typical for the movement as a whole, celebrating the notion of achieving unity and prosperity for most people through the activities of the public sphere.

Over the course of 1913 and the beginning of the following year, Carroll joined with the Progressive Business Men's Club and other organizations like the Grange and the Consumer's League to form the Public Market Association. ${ }^{90}$ Members spoke at public forums, organization meetings, and any other medium they could to generate dialogue and increase support. On March 28, 1914, the group adopted the support and sponsorship of

\footnotetext{
87 "Plaza Blocks to be Public Market," The Oregonian, May 15, 1913.

${ }^{88}$ John F. Carroll, "Need of A Public Market," The Evening Telegram, April 8, 1913; and "John Carroll Dead," The Oregonian, December 5, 1917.

89 Carroll, "Market Needs," The Evening Telegram, April 21, 1913.

${ }^{90}$ Eigo, A Market for the City: The History of Portland's Public Market, 10.
} 
thirty other organizations, clubs, and granges during a publicity event named "Public Market Day and Ladies Day," with Mayor Harry Russell Albee serving as chairman of the occasion. In the eyes of organizers, women (or housewives to be more specific) were central to the idea of the public market in their role as consumers. Event invitations addressed the connection between "Public Market Day and Ladies Day," "Most of our marketing is done by ladies - That is why they should be present," the invitation explained. ${ }^{91}$ Following the assembly, the much enlarged organization renamed itself the Producers and Consumers Public Market Association and elected Eugene Brookings, the head of the Progressive Business Men's Club, as president. ${ }^{92}$ By the middle of April, Mayor Albee had officially joined the public market campaign and after meeting with Brookings, Carroll, and other leaders, the association took its case to the commission.

Finally, on April 19, 1914, the commission officially declared that Portland would get a central public market on Yamhill Street between Third and Fifth Streets. ${ }^{93}$ While the commission did designate space for the market, it did not believe that a permanent building was an option. Instead, commissioners drew up plans for curbside market along the street and allocated a meager two hundred and fifty dollars for the project. Still, Ordinance No. 28905 was approved in May, creating Portland's first municipally owned public market. Few rules were established at this point but oversight was given to a "Market Board": the Producers and Consumers Public Market Association. ${ }^{94}$

\footnotetext{
91 “Progressive Business Men’s Bureau Invitation to 'Public Market Day and Ladies Day,”' March 28, 1914. Correspondence 1914 - P - Public Market, A2000-003, City of Portland Archives, Portland, OR.

92 "Public Market in 2 Weeks Forecast. Producers' and Consumers' Association Organize to Establish Trade Center," The Morning Oregonian, March 28, 1914.

93 "Market Plans Are Made," Oregonian. April 19, 1914.

${ }^{94}$ City Ordinance No. 31672: Establishing and Controlling the Carroll Public Market. April 28, 1916, Public Market Folders, Oregon Historical Society, Portland, OR.
} 
During the initial months of operation, the Carroll Public Market hosted between forty and sixty vendors on any given day Monday through Saturday. Saturdays revealed the true degree of support from consumer and producers. With only forty stalls in the one hundred and eighty feet of shelter, more often than not farmers were selling off the backs of their trucks or being fitted two vendors to a stall. Under the management of the Producers and Consumers Public Market Association, it became obvious shortly after opening that the market needed to expand. Within two months, on July 11, 1914, managerial control was placed more formally under the city. With the passing of Ordinance 31672, the market was positioned under C. A. Bigelow, Portland's Commissioner of Finance. Closely affiliated with the Eastside Improvement Club, Bigelow had supported the idea of a public market during the campaign. It was his report in the beginning of July that convinced the city commission to assume ownership of the institution. Bigelow remained the market administrator for the bulk of the market's life and the remainder of his political career, resigning in 1930. Within the first few months, the market was renamed the Carroll Public Market in honor of one of its central progressive advocates, John F. Carroll.

In the end, the need for a public market appeared to be greater than anyone had anticipated. The grand display of civic cohesion presented on the Carroll Public Market's opening day celebrations moreover, illuminated the cultural role of a facility conceptualized as a point of exchange between rural and urban people as well as producers and consumers. Support for the cooperative identity of the public market was widespread. In August 1915, the Lents Grange reportedly "went on record" to declare that the Carroll Market was "bringing the producer and consumer together as never before." In the same newspaper article, urban approval was cited by Mrs. Wetherred, the only female member on the board 
of control for the State Fair, who stated that "it was the one institution for which the farmers and progressive citizens had been contending for years." 95

During a time when Portland envisioned itself as a potential major metropolis and an ideal meeting point for farm and urban connections, the idea of acquiring a public market was portrayed with populist and progressive rhetoric. Advocates believed that a municipally owned public market strengthened local economy (as in Portland and its hinterland) and serve as an institution that embodied the cooperative and civic minded ideals of both producers and consumers. All through the next two decades, the Carroll Market remained an economic success by serving as an institution of Portland's geographic, commercial, and politically cultural pride.

The parade that signaled the beginning of the Carroll Market in May 1914 illuminated the diversity of group identities that subscribed to the public market's values. While it was based on a cooperative relationship of exchange between producers and consumers, decades of commercial, environmental, and political development throughout Oregon created new understandings of both rural and urban identities. In the context of the public market, producer meant farmer or rural inhabitant while consumer meant urbanite. Each considered themselves members of different worlds and it was through the public market that they could shatter the barrier that had been established by middlemen and investors. To be clear, these people were not fighting for a new definition of community, rather they were fighting for an institution that worked to benefit both ends (producers and consumers) of the supply chain. And, it was hoped, that creating a public market in the commercial center (downtown) of Portland (the commercial center of Oregon) that the

95 "Market is Upheld," The Oregonian, August 16, 1915. 
Carroll Market could lead a change in the culture and process of food distribution, one that benefited both producers and consumers.

In the case of the Carroll Public Market and several other political issues, many populist and progressive Oregonians shared an agreement of values that helped maintain a lasting populist presence during a robust progressive period. For people in rural and urban places, this instance of cooperation was important because it showed that their distinct political and geographical identities could have similar goals and values. During the late nineteenth and early twentieth centuries, rural producers found themselves increasingly relating with urban consumers. ${ }^{96}$ Public markets became important symbols of the relationships between producers and consumers, rural and urban places, and to a lesser degree over time, populists and progressives.

Over six decades of history were compounded into the creation of the Carroll Public Market in which relationships between politicized urban and rural environments, and a realization of common interest between producers and consumers was utilized. Under the protection of a valued government, both producers and consumers felt they were participating in an institutional community. The Carroll Public Market was a celebration of the associated cultural values and geographical identities within that community, but in the minds of those involved, it was also a justified need.

\footnotetext{
${ }^{96}$ Historians like Larry Lipin have discussed this point to some degree arguing that Oregon's working class defined themselves as producers until the early twentieth century when they started to define their status through consumerism. The change drove a wider spread of appreciation for conservation and eco-tourism; two values that Oregon's unions had not found to be in their interest until the advent of the automobile. Lipin, Workers and the Wild, 117-119.
} 


\section{-Chapter Two-}

\section{A Prosperous Environment}

After decades of economic, social, and political development throughout the late nineteenth and early twentieth centuries, Portland experienced an "unprecedented" boom in commercial activity. ${ }^{1}$ Following on the coat tails of the 1905 Lewis and Clark Exposition's boost to publicity and the earlier annexations of Albina and East Portland in 1891, the city's economic activity was flourishing. In 1983, historian Carl Abbott remarked in his book, Portland: Planning, Politics, and Growth in a Twentieth Century City, "Times in Portland have never again been so prosperous as during the years from 1905 to 1912. Every statistical indicator told the same story of sustained economic growth. An extraordinary boom pushed up the value of new building permits by 400 percent, from $\$ 4,183,368$ in 1905 to $\$ 20,886,202$ in 1910"2 Commentators of the time shared the same sentiments. In April 1910, the Oregonian declared that "about the first of the year came a realization stronger than ever before that here in Portland is located the site for a great metropolis," one day that could become, "one of the nation's greatest manufacturing, shipping, jobbing, and retail centers." 3 The addition of St. Johns and Linnton in 1915 only strengthened thoughts about the city's metropolitan potential. Like many other American cities, Portland's growth encouraged more city planning and coordination to maximize the increasingly complicated networks of social and commercial behavior. The resulting effect was the solidification of the "downtown" or centralized business district.

\footnotetext{
1 "Realty Activity is Unprecedented," Oregonian, April 3, 1910.

2 "The volume of banking transactions increased by 150 percent. The rate of employment growth outpaced population, which itself leaped up nearly twenty thousand a year." Abbott, Portland: Planning, Politics, and Growth in a Twentieth Century City, 50-51.

3 "Realty Activity is Unprecedented," Oregonian, April 3, 1910.
} 
"Downtown" in the United States was a difficult place to specifically define but it was usually characterized by the most expensive real estate, greatest concentrations of consumer activity, and most varieties of access (wide avenues, street cars, subways, ferries, etc.). ${ }^{4}$ As Portland matured in the early decades of the century, greater attention was given to the downtown and its potential. The Carroll Public Market's location along Yamhill Street rested just outside the city's choice business blocks, and by 1920, it had become a border street for the emerging retail center. The history of this market is intimately linked with the growth of Portland's urban core; it is difficult to understand the development of one without addressing the other. Ultimately, the Carroll Public Market's immense support contributed to the definitions of the city's downtown commercial environment as well as charging its own occupied space with historically cultural value. This chapter will attempt to identify the relationship between the public market and Portland's central business district by tracing the evolutions of both.

For purposes of comprehending these separate developments, Chapter 2 will examine three topics to show the growth of both places. The first section, A Central Location, will detail the emergence of Portland's downtown commercial district prior to 1914 and describe how the Carroll Market's location was chosen. The next segment, A Producer's and Consumer's Ideal, will describe how the market adhered to its cultural values as well as modifying itself for the modern world, building producer and consumer support over the course of twenty years. Lastly, A New Commercial Environment will show how the market effectively created commercial prosperity along Yamhill Street, aiding in the expansion of the city's downtown further south and east.

${ }^{4}$ Fogelson, Downtown: Its Rise and Fall, 1880-1950, 12-13. 
The Carroll Public Market may not have been as effective at determining premier commercial space as other developments (parking structures, streetcars, and taller buildings) or even other well-known businesses, but it carried considerable cultural relevance among specific groups and supporters, such as the Oregon Grange, urban Housewife groups, and Progressive Business clubs. During the market's existence, Portland grew into a state metropolis as well as a modernized city. In many ways, the Carroll Market was a nod to America's past models of the relationships between community and food distribution, a seemingly simpler time that relied on personal relationships and moral traditions rather than price alone. Despite the financial and cultural success of the market, by the mid-1920s it was unable to adjust to the expectations of modernization in Portland's commercial district. Even though it was torn down in 1934, it managed to influence the shape of the downtown commercial environment as well as endowing the neighborhood it inhabited with cultural significance.

\section{A Central Location}

Portland's business and residential "center" has always resided within a sloped area on the west side of the Willamette River nestled against the steep western hills. This space was never truly the geographic center for the city's population because of the hills. As the city acquired more land consequently, it expanded outward from this location in every direction but west. So while western Portland has always been the social, cultural, and commercial "center" or heart of the city, it took until the first decades of the twentieth century to fill up much of the area with central downtown features like high-value real estate, 
dense commercial retail districts, and crowded avenues of transportation. Throughout the city's life, the Downtown moved around West Portland as well as expanding and reducing in size due to shifting demographics, new retailers and investors, and the development of choicer land. This unstable environment produced regular population shifts (especially for the Chinese community) and made it harder for larger private and public investments to take root. In 1910, the blocks near the waterfront and up Yamhill Street were a patchwork of poor Chinese residents and struggling businesses. Later, the placement of the Carroll Market along Yamhill in 1914 became an opportunity moment for producers, consumers, and the neighborhood businesses.

Like many cities built along the water, Portland's initial commercial environment existed almost entirely along the waterfront. In the 1840s, the river provided a maneuverable launch site for maritime trade as Portland's first settlers created a clearing in which to build homes. By 1860, with the success of merchants like Aaron Meier, Portland's waterside street, Front Street, became the main commercial district. ${ }^{5}$ Docks and general stores lined the river for easy access to shipping. Within ten years though, increased population and economic activity pushed the business core northward and off of the water toward the city's first market building, Ankeny's New Market and Theater. ${ }^{6}$ According to historian E. Kimbark MacColl, in the early seventies, many of "Portland's more successful merchants, shippers, and professionals began trading in their first small, white New England-style frame houses for larger and more elaborate ones, called 'mansions." ${ }^{\prime 7}$ The ascension of wealth was fueled

\footnotetext{
${ }^{5}$ John M. Tess, Uphill Downhill Yambill: The Evolution of the Yambill District in Portland, Oregon (Washington, DC: National Trust for Historical Preservation, 1977).

${ }^{6}$ Ed. Powers, Ankeny's New Market and Theater.

7 This building boom was dominated by Portland's richest six men: Alex P. Ankeny, Henry W. Corbett, Henry Failing, S. G. Reed, Joseph S. Smith, and Frank Dekum. MacColl, Merchants, Money and Power: The Portland Establishment 1843-1913, 183-185.
} 
first by the steamboats, and later by the railroads. During the turn of the century, every year brought new people, wealth, and commercial opportunity to Portland.

Despite the cultural attractions of institutions like Ankeny's public market and theater, a population increase of nearly 560 percent between 1870 and 1890 moved the business center again, westward toward the dryer land closer to the hills. ${ }^{8}$ Even with the large land additions of Albina and East Portland in 1891, the city's downtown remained on the west side of the river. According to MacColl, the financial centralization of the area was maintained and promoted by wealthy investors who had much to lose if the district switched sides of the river. ${ }^{9}$ Investors like William S. Ladd even financially backed residential development on the east side in hopes of maintaining a trend of separation between each side of the river. ${ }^{10}$ Ladd, like other investors, wanted West Portland to evolve into a bustling downtown district in order to earn incredible payoffs on increasing land values and commercial activity. Centralization, as many urban investors around America learned during the late nineteenth century, encouraged the sustainability of increasing profits.

Investments in transportation to increase access and mobility to the central business district also encouraged the consolidation. While it was some time before Portland stopped using ferries, bridge building and street railways experienced incredible growth between 1880 and 1920. In 1887, the first Morrison Bridge was opened and by 1891, two other bridges, built by rail companies, crossed the Willamette. ${ }^{11}$ The construction of bridges began the

\footnotetext{
${ }^{8}$ In 1870, Portland's population was 8,293. In 1890, Portland's population was 46,385. US Bureau of Census, "Population Statistics for Portland, OR (1860-1890)," Washington, DC: Government Printing Office, http://www.census.gov/prod/www/abs/decennial// (accessed January 25, 2013).

${ }^{9}$ MacColl, The Shaping of a City: Business and Politics in Portland, Oregon, 1885-1915, 118-119.

${ }_{10}$ William S. Ladd's, Ladd's Addition, was Portland's first residential development block specifically designed for creating residential communities. MacColl, The Shaping of a City: Business and Politics in Portland, Oregon, 18851915, 122.

${ }^{11}$ MacColl, The Shaping of a City, 80.
} 
development of street railways in 1889 in an effort to connect neighborhoods all over the city. These investments increased access to the downtown as well as reinforcing the separation of the commercial center and other residential neighborhoods. Residential development projects like Sellwood, Ladd's Addition, and Sunnyside were often accompanied by railway lines that all led to West Portland. ${ }^{12}$ Rail lines constituted an essential ingredient of transportation and development in Portland and by 1912, streetcars and other transit lines had supported the sustenance of well over ten small neighborhoods throughout the city. ${ }^{13}$ As communities developed around investors' plans, the downtown became increasingly solidified. Even with the pace and place of development throughout greater Portland pointing toward the emerging downtown commercial district, the area of West Portland continued to experience dramatic changes as the core blocks of commercial activity shifted.

The unexpected boom and bust of real estate investments created by the roaming commercial heart left behind a wake of devalued buildings and cheap housing in West Portland. During the turn of the century, these forgotten blocks were mainly occupied by growing Chinese immigrant communities. As Portland matured, immigrant communities like the Chinese constituted an integral network of the city's social and commercial development. According to the Bartholomew Report for city planning in 1931, it was Chinese occupation along the waterfront that urged the move of the commercial center away from riverside. ${ }^{14}$ It should be understood that the streets from Front to Third roughly bounded by Clay and

\footnotetext{
12 MacColl, The Shaping of a City, 121.

${ }^{13}$ In the ensuing decades, automobile traffic would supplant the train but it was those rail lines that molded the neighborhoods and networks of Portland. Abbott, Portland: Planning, Politics, and Growth in a Twentieth Century City, 52-53.

14 Bartholomew and Associates, "Summary of the Report on a System of Major Streets and A Plan for the Waterfront," December 31, 1931, Bartholomew Report, City of Portland Archives, Portland, OR, 308.
} 
Oak were well known to have the least protection from the elements. Between 1862 and 1894, at least three major floods and two devastating fires ravaged the communities and business along the water. ${ }^{15}$ While anti-Chinese sentiment surely must have helped to devalue the land, the physical environment was far from safe or stable and the shifting of the commercial core was primarily due to greater investments and development in choicer, dryer land.

Portland's first permanent Chinese community existed as early as 1865 , with a reported two hundred residents. ${ }^{16}$ Settlement was varied throughout the city, but much of it concentrated on the western waterfront along Front Street, where some of Portland's first businesses and residences had been set up. During these initial decades, some attempts were made by white citizens and city council members with the "Ordinance to Prevent Chinese Using Any Building or Dwelling House for Habitation within Certain Limits," to legally restrict Chinese to specific parts of the city. This ultimately proved unsuccessful, however, and according to historian Marie Rose Wong, the most successful forms of restriction came from individual property owners who refused to rent to Chinese or charged exorbitant amounts. ${ }^{17}$ By 1870, two distinct Chinese communities had formed in Portland: one urban group of laborers and merchants occupied the waterfront from Front Street to Second, and centered between Yamhill and Alder, and another rural group of farmers and peddlers resided in the westward border of downtown, Tanner's Gulch. The Gulch was a lush and

15 Tess, Uphill Downbill Yambill: The Evolution of the Yambill District in Portland, Oregon, 63.

16 Wong, 204.

17 Wong, 205-209. 
steeply sloped farm land with a creek at the bottom. In 1889, Chinese farmers cultivated more than twenty one acres of the gulch "by utilizing every available square inch." 18

Between 1870 and 1930, both communities experienced dramatic changes as a result of the expanding commercial core. The urban Chinese formed what could be considered Portland's “Old Chinatown.” Many of the Chinese-occupied buildings functioned as residences and business, creating a tight knit community of culture and commerce. The area along the waterfront was well known for flooding and the natural devastation greatly deterred investors and Portlanders outside of the Chinese community from buying and selling property in that part of town. In the end, regular flooding did little to deter Chinese neighborhood building and by 1873, a cultural focal point had begun to form around the intersection of Alder and Second streets. ${ }^{19}$ That same year, a tremendous fire burned twentytwo blocks along the waterfront from Clay until Morrison and west to Second Street. Many of the waterfront buildings were old wooden and brick buildings leftover from Portland's earlier years and did not meet the more recent fire code regulations. ${ }^{20}$ By 1875 , the area was rebuilt adhering to the ban of wood framed buildings. The fire and the ban pushed many Chinese northward toward the area surrounded by Alder and Second, as other older buildings were torn down to meet the fire code. ${ }^{21}$ Until the flood of 1894, the Chinese community along the waterfront continued to flourish. ${ }^{22}$ Afterwards, nearly all high-value commercial and residential activity moved decidedly away from the river, as Chinese

\footnotetext{
18 Wong, 207.

${ }^{19}$ Wong, 243.

${ }^{20}$ Tess, Uphill Downhill Yambill: The Evolution of the Yambill District in Portland, Oregon, 16.

21 Wong, 248.

22 Wong, 253.
} 
populations drifted northward and the core business district began to move into the area bounded by Third to Sixth, and Alder to Washington Streets. ${ }^{23}$

The Chinese population ultimately peaked in 1900, with the developed Chinatown district clustering on the north and south sides of Burnside Street just a couple streets away from the river. The final acts of Chinese displacement occurred after the waterfront buildings experienced another fire in 1906. Coupled with downtown commercial development on soaring property values and an active City Council focused on the goals of the City Beautiful Movement, Chinatown was pushed permanently north of Burnside and off of the river by $1926 .{ }^{24}$ The Chinese Garden community in Tanner's Gulch experienced similar pressures caused by the modernization and expansion of Portland's downtown district. The first reduction occurred in 1893, when the Multnomah Amateur Athletic Club began to acquire land along the slopes for recreation and sports viewing. ${ }^{25}$ The year 1910 marked the end of the Chinese Garden community as the Club and other developers continued to expand into the Gulch. ${ }^{26}$ The peddlers that often came from these gardens were struck an additional blow when the City of Portland outlawed produce peddling in the emerging downtown district east of the Gulch. It should come as no surprise that the outlawing of produce peddling coincided with an increased effort by urban progressives and rural populists to establish a municipal public market. On one hand, supporters truly wanted

23 Bartholomew and Associates, "Summary of the Report on a System of Major Streets and A Plan for the Waterfront," 309.

${ }^{24}$ Wong, 253-261. The City Beautiful Movement was one of the first nationwide efforts to increase the role of planning in urban spaces. While considered an overly idealistic movement with relatively few lasting developments, it laid the groundwork for a permanent dedication to city planning. This will also be discussed further in Chapter 3..

25 Wong, 215.

26 Wong, 219. The only other established immigrant community that farmed land within the city limits were Italians living along Second Street on the east side near the river and in Ladd's Addition. The group was assembled as the Italian Ranchers and Growers Association (IRGA). While there is little information concerning them in the historical record, it is known that until 1908, these gardeners sold produce on the west side in the downtown. They later relocated to a permanent building in the inner SE near the existing gardens. 
municipal involvement in food distribution for regulatory purposes. On the other, there appeared to be a clear racial bias and disregard for the Chinese community that had already supplied produce to Portlanders for decades. The elimination of the Gulch farms opened a niche in the downtown for the Carroll Market to fill. Whether or not anti-Chinese sentiment figured prominently into the relocation of both the urban and rural communities, it was primarily growing wealth and the creation of a consolidated downtown commercial heart that provided the motivation and power to displace these people so easily.

In 1914, West Portland as a whole had begun to reflect the aspirations of its early investors with higher profile businesses and taller buildings. New department stores from companies like Meier and Frank, and Lipman, Wolfe, and Company indicated the expanding prosperity of Portland's downtown retail environment. Alongside prominent names, downtown also gained twelve and fourteen story buildings. By 1920, Portland had "ninety five buildings of at least six stories, and sixteen of ten or more." ${ }^{27}$ Two new bridges in 1913, the Broadway and the Steel, also increased the centralizing potential of West Portland. This booming commercial environment still had its limits, though. The waterfront streets lacked the robust retail activity that had begun to occur more inland toward the hills, and the first several blocks near Yamhill Street still suffered from the displacements of its Chinese population. Prior to the construction of the Carroll Public Market in 1914, "vacancies and general ill repair" had begun to plague the buildings along the first several blocks of Yamhill. ${ }^{28}$ The neighborhood was in a state of transition that had been caused by the lack of involvement from an enduring residential or commercial community. Yamhill and the

\footnotetext{
${ }^{27}$ Abbott, Portland: Planning, Politics, and Growth in a Twentieth Century City, 53.

${ }^{28}$ Within four years of the Chinese Garden community's demise, growing public concerns over Portland's produce quality and price would lead to the creation of the Carroll Public Market. Tess, Upbill Downhill Yambill: The Evolution of the Yambill District in Portland, Oregon, 25.
} 
waterfront also fell outside of the commercial retail core; their "undesirability" left them without the resurrecting capital of wealthy investors that had been reserved for choicer land farther off of the river. Without either, the blocks of Yamhill provided an inexpensive formative ground and malleable commercial environment for the public market.

While the campaign for the creation of a municipally owned public market came to a head in 1914, positioning it was a complicated issue. As of February 1914, the old Market block (between Second and Third, and Clay and Market streets) that had been used for peddling and informal marketing by Chinese, Italian, and white farmers was taken off of the table, as the City Council approved the site for the location of the new Portland Civic Auditorium. ${ }^{29}$ This decision haunted the public market for both decades of its life. While many public market supporters wanted a large permanent structure, the city council was still skeptical of investing a large sum in the endeavor. On top of this, the real estate boom of the previous decade had pushed property values extremely high. In an effort to satisfy both the cultural desires of producers and consumers as well as the budget constraints of the fiscally minded City Council, Mayor Harry Russell Albee commissioned Marcus Cohn in the beginning of April to investigate the appeal of a curbside market along Yamhill Street. Within days, Cohn reported back to Albee saying, “...the writer interviewed nearly all of the merchants on the said street and they are all in favor." 30

Support from businesses and property owners along the block ran extremely deep and when the Carroll Market was expanded from its initial location between Third and Fifth

\footnotetext{
${ }^{29}$ Since being donated by Col. Chapman in 1851 for the development of a municipal public market, the Market Block was used for informal produce peddling until 1914 when the city began the development of the civic auditorium on the site and the Carroll Market was created. MacColl, The Shaping of a City: Business and Politics in Portland, Oregon, 1885-1915, 452-453.

${ }^{30}$ Marcus Cohn, Marcus Cohn to Mayor Albee regarding interviews along Yamhill, April 4, 1914, Correspondence -C- Public Market, A2000-003, City of Portland Archives, Portland, OR.
} 
down to First Street in 1916, owners from the blocks pooled their money to donate nearly half of the expenses. ${ }^{31}$ Most likely, the contributions were far from acts of generosity; these donations were investments for a struggling neighborhood that desperately needed more consumer foot traffic. Owners along the block knew that the cultural attraction of a civic institution and the consumer demand of a producers' market would pull a sizable crowd of retail activity. After the opening day parade where thousands of people and thirty organizations attended, it became obvious that the popularity of the public market was escalating. ${ }^{32}$ As a curbside market, it was able to stay out of the real estate game while still commanding an institutional presence in the area, effectively doubling the potential of consumer attraction along the Yamhill blocks between Fifth and First.

Throughout the next two decades, the Carroll Public Market continued to build support by adhering to the core cultural values constructed by producers and consumers over the previous decade. After Portland's downtown commercial core had slowly shifted around West Portland for fifty years or so, it finally settled between Fifth and Broadway Street close to Burnside during the 1910s. ${ }^{33}$ The displacement of the Chinese community combined with the destruction of flood and fire left business along the waterfront desperate for renovation and consumer activity. As the public market solidified its cultural role and physical presence in the city, it played an increasingly important function in the resurrection of Yamhill's commercial environment.

\footnotetext{
31 The total cost of the expansion was $\$ 8,838.76$. Property owners donated $\$ 3,891.00$, leaving the city a net cost of $\$ 4,947.76$. Bigelow to National Municipal Review, January 18, 1916, Carroll Public Market Papers, A2000004, City of Portland Archives, Portland, OR.

32 "Pageant in which Thousands Participate Marks Formal Opening of Portland Public Market on Yamhill Street," The Morning Oregonian, May 17, 1914.

33 Abbott, Portland: Planning, Politics, and Growth in a Twentieth Century City, 53.
} 


\section{A Producers and Consumer Ideal}

After less than a year of activity, Commissioner C. A. Bigelow proudly confirmed that the market was producing a steady profit. In December 1914, the Progressive Business Men's Club held a conference at the Multnomah Hotel for "city officials, producers, and consumers" to "testify to the institution's success." 34 Familiar faces from the parade in May attended: the Commercial Club, Rotary Club, Bigelow, members of the Grange, housewife advocates, and John Carroll (stylized as the "father of the public market") for the closing speech. Many of these people and groups continued to play a role in the evolution of the market, particularly housewives, who acted as consumer advocates and unofficial market supervisors. The congratulatory cheer continued into 1915 when Bigelow wrote a piece in The Oregonian titled, "Portland's Public Market is A Signal Success" for the first of the year. ${ }^{35}$ In the article, Bigelow openly shared the financial summary and producer count to date, showing that the market had made at least $\$ 800$ over operating expenses for a total of $\$ 1,515.95$ in receipts with at least five hundred producers participating. ${ }^{36}$ As a supporter and the Commissioner of Finance for the city, Bigelow never shied away from revealing the flow of capital at the public market. His candidness was only matched by his strict dedication to the rules of the market in order to benefit producers and consumers. On April 7, 1915, in a letter to Frank Cassidy, a regular patron, Bigelow declared: "We are controlled... absolutely

\footnotetext{
34 “Public Market Now Pays," The Oregonian, December 11, 1914.

35 Bigelow, "Portland's Public Market, Launched in 1914, Is A Signal Success," The Morning Oregonian, January 1, 1915.

${ }^{36}$ Bigelow to Mrs. Josephine R. Sharp, February 15, 1920, Carroll Public Market Papers, A2000-004, City of Portland Archives, Portland, OR.
} 
with one thought, that one thought of the greatest good to the greatest number." ${ }^{37}$ Bigelow's conviction in the Carroll Market's civic value, along with the lasting support of producers and consumers, ensured that it continued to evolve without sacrificing the cultural foundation on which it had been built.

The rules of the market changed little over the twenty years, but when they did, it was often an organic process, with small adjustments that either increased transparency or regulated unfair competition. By 1915, Commissioner Bigelow had a quick sheet of twenty rules for governance of the market drawn up by J. A. Eastman, the market master. ${ }^{38}$ The public market ran six days a week (Monday through Saturday) from 6:30 AM until 6 PM, except for Saturday, the busy day, when it closed at 9 PM. The market rarely shut down, even during the winter, and only did so during times of extreme weather. ${ }^{39}$ Stalls were rented at ten cents for farmers and twenty-five cents for associations. Associations were banned from the market in 1917, as they became the primary violators of the rules and were much harder to regulate. ${ }^{40}$ While some farmers appreciated the ability to collectively sell, it also gave them a competitive edge in price over individual farmers. Common violations of associations included occupying more than one stall, using a commissioned based agent to sell goods, and not properly labeling the origin point for all sellable goods.

Bigelow and Eastman took these rules very seriously and while they wanted to benefit the producers, they believed that the lasting success of the market was, "in the

\footnotetext{
${ }^{37}$ Bigelow to Frank Cassidy on Market Activity, April 7, 1915 Carroll Public Market Papers, A2000-004, City of Portland Archives, Portland, OR.

38 Rules Governing the Carroll Central Market, 1915, Carroll Public Market, A2000-004, City of Portland Archives, Portland, OR.

39 "Old Yamhill Market Once Famed Portland Sight," The Oregonian, August 1, 1965.

40 Bigelow to Alice E. Elliot Regarding Associations, March 22, 1917, Carroll Public Market Papers, A2000-004, City of Portland Archives, Portland, OR.
} 
interest of the consumer first, and the producer secondly." ${ }^{41}$ Bigelow and Eastman both believed that this was a mutual relationship though in which each member of the transaction assisted the other. Every producer was given a rule book with the ordinance and regulations detailed. The purpose of the market was outlined in a foreword written by Eastman, "To the Producers: The success of the Carroll Public Market and of the producer are closely interwoven. One cannot succeed without the other, and neither can succeed without the consumer." ${ }^{42}$ In other words, by focusing on the consumer the institution and thus the producer would benefit. The notion was not idealistic and even fell in line with the practice of most grocery businesses. Where the Carroll Market differed though, was that it was comprised solely of individual localized farmers (producers) who had a relationship with Portland, whether they liked it or not. The market gave them a chance to serve their products directly to the commercial metropolis for the best price.

Of all the rules, the most important were those that eliminated middlemen. In the letter to Frank Cassidy, Bigelow addressed the complaint that no bread was being procured at the market. "In regard to the complaint of bakeries," he explained to Cassidy, "you must realize that the person selling bakery goods must buy the flour, seasoning, lard...all ingredients." 43 If a vendor did not completely produce the goods he sold, they could not be sold at the Carroll Public Market. Over the years, Bigelow dealt with scores of concerns from consumers, consistently restating the rules and reasons for the market in his responses. Rejecting the role of the middleman was essential and absolute to the enterprise, making the

\footnotetext{
41 Bigelow to Frank Cassidy on Market Activity, April 7, 1915, Carroll Public Market Papers, A2000-004, City of Portland Archives, Portland, OR.

42 City Ordinance No. 31672: Establishing and Controlling the Carroll Public Market. April 28, 1916, Public Market Folders, Oregon Historical Society, Portland, OR.

43 Bigelow to Frank Cassidy on Market Activity, April 7, 1915, Carroll Public Market Papers, A2000-004, City of Portland Archives, Portland, OR.
} 
potential profits for independent producers much greater. Needless to say, the Carroll

Market was very popular among farmers who were fortunate enough to secure a stall.

Word of the market quickly spread throughout the Northwest and as early as Fall

1915, Bigelow was rejecting farmers from California, Washington, and Idaho with the

following explanation:

The reason therefore was because it was deemed advisable to restrict the market to producers raising produce within the commercial adjacent territory to Portland. By trade territory is meant communities that purchase and sell nearly all supplies through the city. With reference to Washington, the distance from which producers may come is also limited. We find it necessary to occasionally to visit places from which produce comes to verify legitimate production, and therefore is another added reason why the distance must be so limited. ${ }^{44}$

The notion of the public market as a localized institution rarely came up during the years leading up to its inauguration. Bigelow seldom spoke of the market in terms of local economy. His exclusive focus rested on eliminating middlemen practices and creating a better commercial habitat for producers and consumers. In the public market, producers could get better prices by serving their local municipality, while consumers could get better qualities of produce and lower prices because the produce went directly from the farm to their table. As a result of Bigelow's policies though, the Carroll Market became grounded in a localized system of exchange, making it personal for all who involved themselves in its activities and community ideals. Inspired by the public market, Mrs. Alva Lee Stephens led the women of Portland's Parent-Teacher Associations in 1917 in a campaign to initiate gardening work programs for school children. Her ultimate hope was to create a separate public market strictly for the produce grown by the children. Chairman Mrs. W. I. Swank remarked on the program: "The country boy-learns early that he must assist in the work on

\footnotetext{
44 Bigelow to H. P. Mumma, September 13, 1915 Carroll Public Market Papers, A2000-004, City of Portland Archives, Portland, OR; and Bigelow to D. H. Detchon, November 9, 1915, Carroll Public Market Papers, A2000-004, City of Portland Archives, Portland, OR.
} 
the farm. The city boy has much time to idle instead of producing the necessities of life. It is hoped that home gardens for girls and boys will help to make the city girls and boys producers." 45 Not unlike the cooperation experienced by rural and urban promoters of the Carroll Market, Portlanders who supported the system's values attempted to reflect the ideas outward on their community. The ethics of the market conceptualized the urban consumer and rural producer as members of the same community, tying them together through food distribution.

Due to the reliance on localized goods, the market also sold seasonally; turkeys lined the market near Thanksgiving, flowers were sold on certain days through the Spring and Summer months, and even Christmas trees made their way to it during the Winter. Goods varied widely, but most items were fruit and vegetable produce: tomatoes, eggs, fryer chickens, green beans, butter, apples, milk, pears, potatoes, lettuce, corn, etc. ${ }^{46}$ Retail cost, or the price at local grocery stores, guided the maximum prices allowed for the producers at the Carroll Public Market. The maximum was set every morning by Market Master Eastman, serving as an up-to-date reflection and response to Portland's grocery costs. While Eastman always set the market's price below retail cost, it was the activist housewives who kept the closest watch over prices, as Portland's grocery stores attempted to compete against the public market.

Throughout the years, Bigelow, Eastman, and Portland's mayors received letters and formal complaints regarding a wide range of issues; none though, was more contentious than price. Letters peaked during World War I, when market patronage was at a low and food

\footnotetext{
45 “Parent-Teacher Council's Aid Big," The Oregonian. May 27, 1915.

${ }^{46}$ Kelly Reese to Mayor Baker on Conditions of Market, October 1917, Carroll Public Market Papers, A2000004, City of Portland Archives, Portland, OR.
} 
costs were high. The advocates behind the public market had always concerned themselves with the opinions of housewives, because they believed that they did the bulk of the shopping. While both men and women played roles as price watchdogs, it was the women that newspapers and city officials privileged. To be sure, both men and women did not always have complaints. In fact, Bigelow received many letters that commented on the exceptional quality or prices of goods.

Opinions of the market started to vary widely between 1917 and 1920, as debate began to circulate that the public market saved the consumer little if anything. The agitation even prompted The Oregonian to begin running articles on the market's "high prices" based on increasing complaints made by housewives. ${ }^{47}$ In 1917, one article declared: "Many Portland women are beginning to wonder if it is really worthwhile going to market, when they can buy very good vegetables at the stores for the same price and delivered.” By 1919, many Portland housewives had organized under the continued efforts of Mrs. J. F. Chapman, chairman of what she called the "Fair Price Committee." 48 The price debate infected all members of the public market's community, and other than a small handful of producers there was hardly anyone who did not want prices lowered. Mayor Baker signaled his stance in a letter to Bigelow in 1919 stating: "If the public market can be made a weapon in the fight against the present high prices," declared Baker, "I am in favor of going to bat.",49 Campaigning by the Fair Price Committee peaked in 1920, when housewife groups were successful in lifting the market's ban on maximum prices, believing it created more

\footnotetext{
${ }^{47}$ E. J. Tucker, "High Prices at Public Market," The Oregonian, April 25, 1917.

48 "Housewives to Aid in War on Prices," The Oregonian, August 8, 1919.

49 Baker to Bigelow concerning Grant Thomas' complaints, August 9, 1919. Carroll Public Market Papers, A2000-004, City of Portland Archives, Portland, OR.
} 
competition among the farmers for lower prices. ${ }^{50}$ To the surprise of the committee, lifting the price ceiling had the opposite effect and for several months in the Fall prices remained higher than before. World War I's effect on food prices had lowered both producer and consumer confidence in the public market. The public debate over the market's ability to keep prices low unsettled the cooperative spirit that had thrust it into existence. Without a large consumer base or market regulations, producers were unwilling to lower prices. On December 23, Eastman reinstated the maximum price fixing. Overnight, the adjustment "lowered prices, in some cases more than cut in half as compared with those of the previous day." While housewife groups did little to push prices significantly lower than the grocery outlets, they actively participated in the shaping of the public market's key values. When price became a central focus for consumers, market officials adjusted the regulatory structure to enhance oversight. By 1921, housewives and other consumers began to trust the institution again, as patronage returned to its earlier levels. ${ }^{52}$

Between 1921 and 1923, the Carroll Market expanded to include first two hundred stalls and then two hundred and twenty five stalls. On Saturdays, the number of producers greatly exceeded the number of stalls and Bigelow made sure to document it. In June 1921, the producer count on Saturdays peaked at three hundred and eighty three vendors. A year later in April 1922, the producer count peaked at three hundred and forty six vendors; in the years following World War I and the Fair Price Committee's efforts, the reinvigoration of

\footnotetext{
50 "Prices are Reduced in Public Market," The Oregonian, December 24, 1920.

51 The Oregonian, December 24, 1920.

52 Receipts from vendors dropped during the war from \$7,525 in 1916 to \$6,611 in 1918. "Portland Public Market is Proving Good Thing for City for Producers and For Public Generally," The Oregonian, October 30, 1921.
} 
support was incredible. ${ }^{53}$ The renewed popularity greatly increased the profits of the market, although even during the most contentious times, the Carroll Market had never experienced a losing year.

With renewed celebratory attention, the public market increasingly began to be seen as one of Portland's notable community institutions. While the Carroll Market survived consumer critiques, the city's other public markets did not. Counting the farmers along Yamhill, at least four public markets were opened in 1914: the Albina Market, the Montavilla Market, and the Central East Side Market, all located outside downtown and near large population centers. ${ }^{54}$ The Albina Public Market had begun just two weeks before the Carroll Market in April 1914 and was situated in northern Portland due to the efforts of the Producers and Consumer Public Market Association. It was never officially taken over by the city, but was guided by the same principles that dictated the organization of the Carroll Market. In March 1919, it closed down after years of dwindling producer and consumer support. The Albina Public Market, like the later Municipal Fish Market, lacked the advocacy and consumer involvement that graced the Carroll Market. With its downtown location, the Carroll Public Market also held a symbolic position as a central civic institution of Portland, as well as benefitting from the increased foot traffic of the denser retail environment.

Portland's only other municipally owned and operated market was the Municipal Fish Market, a project of Commissioner Dan Kellaher and initially supported by Bigelow and Mayor Baker. The Fish Market was originally opened by the Portland Ad Club and taken

\footnotetext{
${ }^{53}$ Bigelow to Mrs. D. M. Watson Concerning Number of Stalls," May 12, 1922, Carroll Public Market Papers, A2000-004, City of Portland Archives, Portland, OR.

54 “Two New Markets Will be Opened," The Oregonian, July, 16, 1914.
} 
over by the city and Kellaher's management in $1917 .{ }^{55}$ Commissioner Kellaher had different ideas of what state controlled markets should be allowed to do. In early 1918, he was able to get a boat from the Port of Portland "rent free" (putting the Port into debt) and even attempted to fish waters not deemed for commercial fishing by the Department of Fish and Wildlife. ${ }^{56}$ Unlike the Carroll Market, the Municipal Fish Market attempted to operate the entire means of production as well as the sale of the fish, effectively creating a socialist seafood enterprise in the city. In January 1919, the Fish Market was placed under Bigelow's management and with the help of Kellaher, purchased the Port's fishing boat that had been used for the previous eight months in service of the Fish Market. Less than five months later, in May 1919, Commissioner Bigelow demanded the market be sold after finding it difficult to operate the institution as well as a fish boat at a loss. ${ }^{57}$ According to Bigelow, the costs of a municipally owned fish boat cost the city three thousand dollars during the last year of operation. Without any reasonable offers for the purchase of the market, Bigelow moved operation of sales to a stall at the Carroll Public Market at the end of May. Two months later, the business was purchased by G. B. Weiss. After 1919 accordingly, the Carroll Public Market was the only municipally owned public market in Portland.

While support for public markets flourished during the 1910s, their popularity was not strong enough to sustain a greater system of them. In the beginning of 1914, before Yamhill Street had been designated as a Public Market, Mayor Albee had even proposed that public markets should be placed throughout the city and that the first could be used as a trial

\footnotetext{
55 "Portland Decides to Run Fish Market," The Oregonian, September 28, 1917.

56 "Port Needs Funds," The Oregonian, September 13, 1918; and "Fish Removal Barred," The Oregonian, June 15, 1918.

57 To be clear, the Municipal Fish Market did experience a good deal of support from groups like the Portland City Club and the Grange. "Fish Market Sold," The Oregonian, July 13, 1919.
} 
to determine the sustainability of the endeavor. ${ }^{58}$ Yet a city-wide system of public markets in Portland was never wholly pursued by the government or any advocacy groups. The lack of enthusiasm for the Albina Market, in particular, demonstrated that location played an important role in a business operation, regardless of its ideological purpose or political support. As a contrast to the Albina Market and the Municipal Fish Market, the Carroll Market was supported by its centralized location near the business district of the city. Centrality, in reference to the downtown, gave the market regular foot traffic, more access through transportation systems, and legitimacy. As an institution of the central business district it occupied the neighborhood of the highest real estate values and largest investments. The market also acted as a blend of private enterprise and public responsibility, a position that made it economically agile.

Not surprisingly, the market's renown attracted the attention of officials outside of Oregon who wondered how and why the Carroll Market operated successfully as a municipal institution. As early as 1915, C.A. Bigelow began to receive inquiring letters from other municipalities in the Northwest. By 1920, he had corresponded with city officials, academics, and investors from all over the country. Throughout the Carroll Market's life, cities like Pittsburg, Dallas, Philadelphia, New York, San Jose, St. Paul, and Columbus sought to replicate the achievement that had manifested in Portland. On a few occasions, Bigelow even sent Eastman to survey and give advice to potential public markets. For both men, the reasoning always stayed the same; the market's success hinged on its location next to the retail business district and its role as a producer-to-consumer market. The Carroll

\footnotetext{
58 Albee proposed a system not unlike Portland's contemporary farmers' markets in which they would be placed according to neighborhoods and would run during certain hours of certain days. "Street Market is Plan," The Oregonian, January 31, 1914.
} 
Market also eventually became a tourist destination for farmers and visitors around the world. As the Oregonian remarked in 1930, "Farmer tourists are coming to Portland in greater numbers than in any previous season" and are "almost invariably taken to the public market on Yamhill Street." 59 The Market was also featured across the country in expositions like the Home and Economic Committee's Civic Exposition in Philadelphia and magazines like the National Municipal Review. ${ }^{60}$ With national praise, high profits, a centralized commercial setting in Portland, and continued support from vendors and patrons, Bigelow implemented few changes to the operational directives and regulations of the market over its twenty years.

By 1930, the Carroll Public Market had successfully navigated a variety of cultural and political interests while managing to quintuple in size and sustain yearly profits close to twice the cost of operation. ${ }^{61}$ Even without considering the market's balance sheet, it was clear that the space served as a public and cultural gravitational point. As a central community space, the market also attracted activists looking to use the market as a public forum. A few such instances occurred on March 8, 1930, when "bridge election solicitors and recall petition passers were met by campaigners looking to get signatures for a ban on cigarettes at the public market." ${ }^{62}$ On any given day, a great deal of information and goods could be exchanged at the market.

\footnotetext{
59 “Those who Come and Go," The Oregonian, August 31, 1930.

${ }^{60}$ Bigelow to National Municipal Review Concerning Errors, January 18, 1916, Carroll Public Market Papers, A2000-004, City of Portland Archives, Portland, OR.

${ }^{61}$ This model of food distribution had not yet gone extinct but it was certainly losing ground on the national level as the trend towards chain stores and supermarkets produced more standardization, less vendor negotiation, and the absence of public space. From a fiscal point of view, the Carroll Market increasingly became an anomaly among public markets around the country; especially so in its later years. Bigelow to $\mathrm{Mr}$. W.P. Andrews of Modesto, California, Specific Date Unknown, 1929, Carroll Public Market Papers, A2000004, City of Portland Archives, Portland, OR.

62 "Cigarette Ban Sought," The Oregonian, March 8, 1930.
} 
Although management policies and the composition of patrons hardly changed, modifications to the market were substantial. By 1934, Yamhill Street from First to Fifth looked very different from its formal self in 1914. Much of the development was led by the popularity of the Carroll Market. Higher real estate values, new retail businesses (mostly food and/or grocery), and large tarp coverings gave the market street a distinct appearance. Through adhering to the anti-middleman values that founded it, the Carroll Market continued to build community support from producers and consumers until its last day of operation in January 1934. Both groups benefitted from the public market system on Yamhill, and its popularity gave the street a new commercial environment.

\section{A New Commercial Environment}

Throughout the market's twenty years, it was not uncommon for newspaper articles and patrons to call the Carroll Public Market a variety of names like Yamhill Market, Central Public Market, or even just Yamhill Street. This mix of terminology was likely unintentional but it spoke to a change that had occurred, as the commercial environment along Yamhill altered. Real estate owner Marcus Cohn's advertisement in 1918 for a building rental along Yamhill Street behind the market illustrates the synonymous use of terms: "Best location on public market for fish and poultry." ${ }^{63}$ Two years later, the Enterprise Realty Company advertised for the rental of "One of the best public market groceries in the city." "Famously, Fred Grubmeyer (later owner of Fred Meyer stores) got his start along Yamhill with a grocery and even after the market had been torn down in January 1934, his advertisements

${ }^{63}$ Marcus Cohn, “Advertisement for Rent on Public Market,” The Oregonian, June 6, 1918.

${ }^{64}$ Enterprise Realty Co, “Advertisement for Rent on Public Market," The Oregonian, March 4, 1920. 
still noted the location as "Fifth and Yamhill Market." ${ }^{65}$ In the minds of many Portlanders, inner SW Yamhill Street and the Carroll Market was the same thing. The stores along Yamhill and the public market evolved together, creating a unique commercial environment.

The market went through several expansions over the years as more producers and consumers participated in its affairs. Prior to closing, the Carroll Market had twelve hundred lineal feet with over two hundred and twenty five stalls covering almost all of the curb space between First and Fifth Streets. ${ }^{66}$ Initially, these stalls were very basic shelters, iron frames with small roofs. The iron stalls protected the market's operations as well symbolically legitimizing the market's presence along the curb. As the years went on, Bigelow felt it was important to give the farmers more protection from the elements and ordered thick tarps to be strung from the buildings down and out into the street. ${ }^{67}$ The tarps entirely altered the visual appearance of the street. Along the sidewalk, behind the market, pedestrians strolled along completely canopied walkways of retail shops and bustling market interactions. On the street, cars parked for short periods of time underneath cover in front of the vendors. This dense and busy environment caused an incredible amount of pedestrian and automobile traffic. As early as 1918, the Portland police began to direct auto traffic and eventually the department assigned one officer, Pasquale Tusi, as the market's personal policeman. ${ }^{68}$ This did not help enough, though, and during the 1920s, Yamhill Street was made one way to relieve the increasing pressures of traffic congestion. The clutter and covering of the street

\footnotetext{
${ }^{65}$ Because of his success along Yamhill, Fred Meyer stores would eventually grow to become one of Portland's largest employers and the Northwest's most common shopping retail stores. "Advertisement for Fred Meyer," The Oregonian, February 18, 1934.

66 "Yamhill Public Market Closes Down After 20 Years of Continuous Service," The Oregonian, January 9, 1934. 67 The Oregonian, January 9, 1934.

68 This article was one of many nostalgic essays done in the decades after the closing of the Carroll Market that seemed to elevate the characters and places to that of legendary status. "Old Yamhill Market Once Famed Portland Sight," The Oregonian, August 1, 1965.
} 
also prompted the installation of a system of lights so that market goers could see clearly in the early and late hours of the day. Over the years, Yamhill Street began to feel like the inside of a market building, a unique out-of-doors experience along the streets of Portland.

Concerns over the market's sanitation systems prompted multiple developments. During the market's first two years, producers were often inconsistent in their cleanup of garbage waste. In response, Commissioner Bigelow initiated a daily garbage pickup in 1917 to relieve the stress of having the vendors clean their own stalls. Sanitary concerns from citizens and city officials also encouraged a standardized definition of what and how building space could be used for produce storage. Between 1918 and 1921, when the market was under intense scrutiny by housewives' groups and concerned citizens, many focused on the conditions of basement storage rooms as proof of the market's unwholesome nature. ${ }^{69} \mathrm{In}$ September 1919, sanitation concerns about the public market became the point of discussion for a "housewives' mass meeting" at the Central Library. Many speakers suggested that the best solution was a permanent building with "avenues on all sides," because in its present condition "We all know that this market of ours is a joke.",70 Anxieties over sanitation cast the market as inferior, a difficult insult to overcome as Portland and food distribution in the city modernized. Following these complaints, Bigelow ordered a standardized set of guidelines for the rooms, and also covered them under the daily garbage pickup. The streets themselves also underwent construction in 1921, as more sewage drains and catch basins

\footnotetext{
${ }^{69}$ Kelly Rees to Mayor George Baker, October 1917. Carroll Public Market Papers, A2000-004, City of Portland Archives, Portland, OR.

${ }^{70}$ Even though one woman called the market a "joke," the group's discussion focused on the future and potential solutions to the state of the institution. Another woman even went as far to suggest that a park block should become the location of the new market stating, "It means more to have a place to buy something to eat than to have a place for men to loaf in." "Women want Whole Block for Market," The Oregonian, September 17, 1919.
} 
were installed to enhance drainage capacity. ${ }^{71}$ Many of these changes were only politically possible because of the market's high profits and low operating costs. This organic development over time had the effect of developing a food orientated commercial environment.

The market had a direct effect on the businesses residing in the buildings behind it as well. In a letter regarding the market's effect on nearby businesses to Mr. D. B. Armstrong, the Director of the Department of Social Welfare for the City of New York, Bigelow stated that:

...previous to the establishment of the Market, the street on which it was located was considered a very poor business street... many being vacant. Since the establishment of the Market rents have doubled, and more than doubled in some instances. Some of the property that was vacant has been improved with modern fireproof market buildings. The general consensus of opinion is that the Market has made Yamhill Street... ${ }^{72}$

Within just a few years, many of the buildings along Yamhill were modernized or rebuilt in response to the new, elevated attention along the street. By 1929, all of the private property shops behind the curbside market were rented by food and grocery stores of one kind or another. ${ }^{73}$ These businesses were very loyal to the Carroll Market and when its closure was imminent at the end of 1933, they stayed devoted to the cause of the old producers. ${ }^{74}$ Alongside Grubmeyer, Yamhill had many food related businesses that included the Rotary Doughnut Shop, Puritan Meat Market, Rotary Bread Store, Campfire Coffee Shop, Honolulu Fruit Company, Ideal Dairy Company, and the Western Cream Company to

${ }^{71}$ Commissioner Barber to Commissioner Bigelow on Drainage Basins, August 18, 1921, Carroll Public Market Papers, A2000-004, City of Portland Archives, Portland, OR.

72 Bigelow to Mr. D. B. Armstrong regarding Market Location, March 8, 1916, Carroll Public Market Papers, A2000-004, City of Portland Archives, Portland, OR.

73 Bigelow to Mr. W.P. Andrews of Modesto, California, Specific Date Unknown, 1929. Carroll Public Market Papers, A2000-004, City of Portland Archives, Portland, OR.

74 "Notice to the Public: We Are Not Moving," The Oregonian, December 23, 1933. 
name a few. ${ }^{75}$ The street even housed at least two privately run markets called the Yamhill Sanitary Public Market and the Central Public Market. The Carroll Market had created a distinct commercial environment along the street, one that focused on food and civic pride.

While the market had a direct economic impact along Yamhill, Portland's downtown was also growing. In 1923, the Carroll Market was considered by Bigelow to be located "but a block away from the business center of the city." ${ }^{76}$ By 1930, the central business district, where the highest real estate values and commercial activity existed, extended between Burnside and Taylor, bordered by Third and Tenth streets, including half of the Carroll Market. ${ }^{77}$ In 1914, the market was along the streets of a somewhat neglected part of Portland's west side. During the following two decades, the market revitalized its own neighborhood and was absorbed into the growing downtown, making it an increasingly conflicted environment for city planners and their vision of a modern central business district.

For roughly twenty years, the Carroll Public Market made its impression on Portland's emerging downtown. By adhering to its cultural foundation's values, the market was able to build support over time. As it evolved, so did Yamhill Street, becoming a bustling neighborhood of grocery, food shops, and farmer stalls below a large weather resistant canopy. It was unique but also specialized, and in that sense, the culture of the Carroll Market directly affected the commercial environment of inner Yamhill Street. What

\footnotetext{
75 After the Carroll Market was closed and the Portland Public Market was opened, many of the old producers opened up a Farmer's Co-Op along Yamhill Street. "Notice to the Public: We Are Not Moving," The Oregonian, December 23, 1933.

76 Bigelow to Poster Advertising Company, Specific Date Unknown, 1923. Carroll Public Market Papers, A2000-004, City of Portland Archives, Portland, OR.

77 Bartholomew and Associates, "Summary of the Report on a System of Major Streets and A Plan for the Waterfront," 318-319.
} 
had once been a poor business street became the pride of Portland, popular for tourists and regularly frequented by the general public.

Location was an incredibly important component of the Carroll Public Market. As shown in Chapter 1, the market was constructed as a response to commercial and political changes in Oregon and around the country. It was placed in the downtown to be a central institution of the city and was supported by a cultural foundation of producers and consumers. The foundation legitimized the market and its function through political advocacy and commercial activity. As a result, the public market remade the neighborhood surrounding it into a greater market. Between First and Fifth streets, the commercial environment of Yamhill was restructured by the Carroll Market's cultural foundation.

The Carroll Market's accomplishments could be measured in a variety of ways, but it is the fact that it produced a symbolic neighborhood with very real physical changes to the commercial location that make it a powerful example of the effect of culture on environment. Measuring the market's specific effect on Portland's downtown is a difficult and potentially impossible task, but it should be understood that as a result of the public market, Yamhill Street helped to redefine the areas of busy retail activity on Portland's west side. Nevertheless, as Portland's downtown continued to develop, the market began to suffer from overcrowding caused by its resounding success. During the 1920s, the Carroll Public Market came in conflict with the expanding retail core, leading to reconsideration of its place in the city's commercial center. 


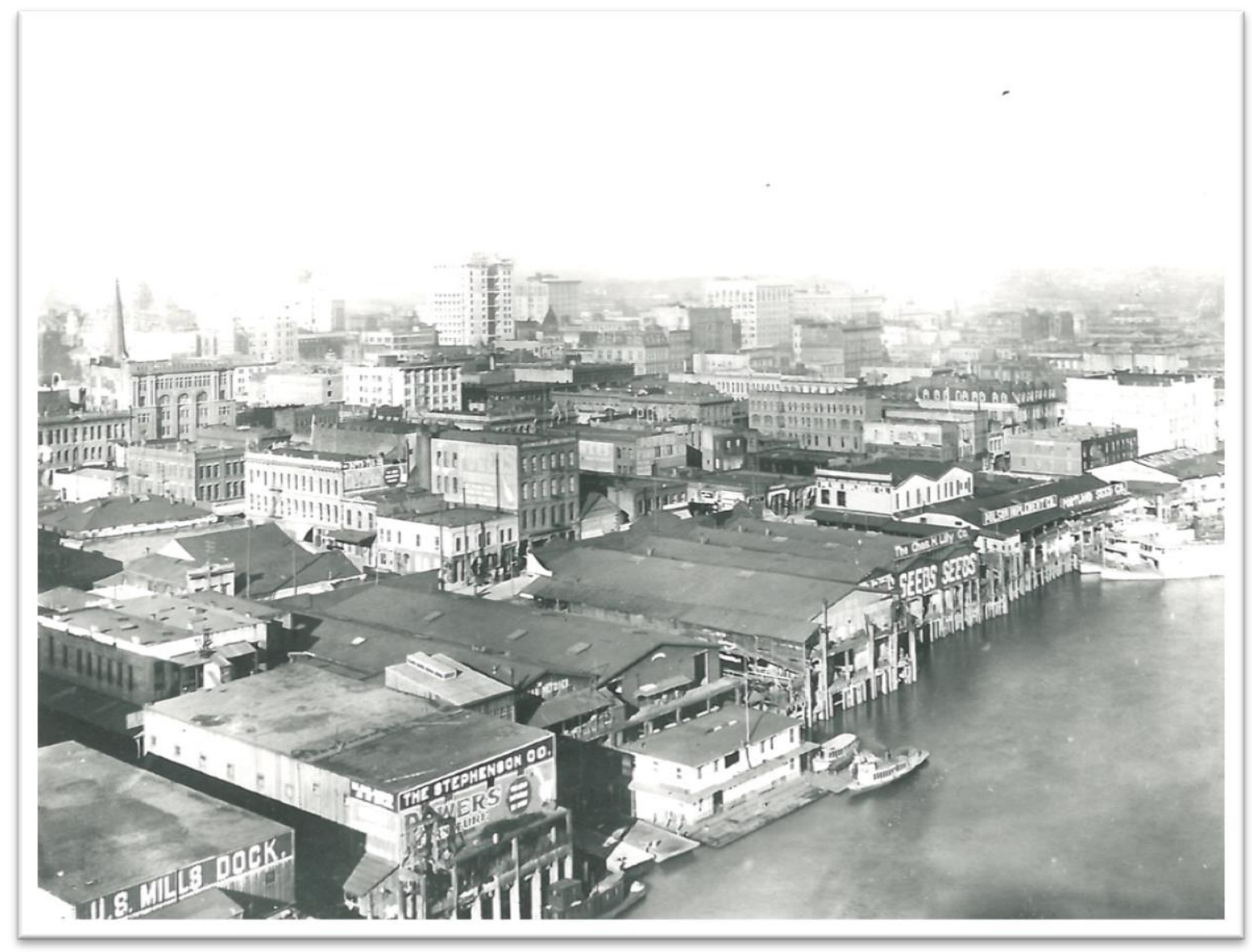

Figure 1 - Portland Waterfront $1912^{78}$

${ }^{78}$ This is a photograph of Portland's waterfront in 1912 taken from the Hawthorne Bridge looking northwest. As you can see, the city's businesses extend into the river and are still making good use of ferries. By the time this photograph was taken, Portland had experienced an unprecedented period of growth and expansion that brought bigger buildings and the generation of a formalized central business district. "Portland Waterfront 1912," ca. 1912, Oregon Historical Society, Portland, OR. 


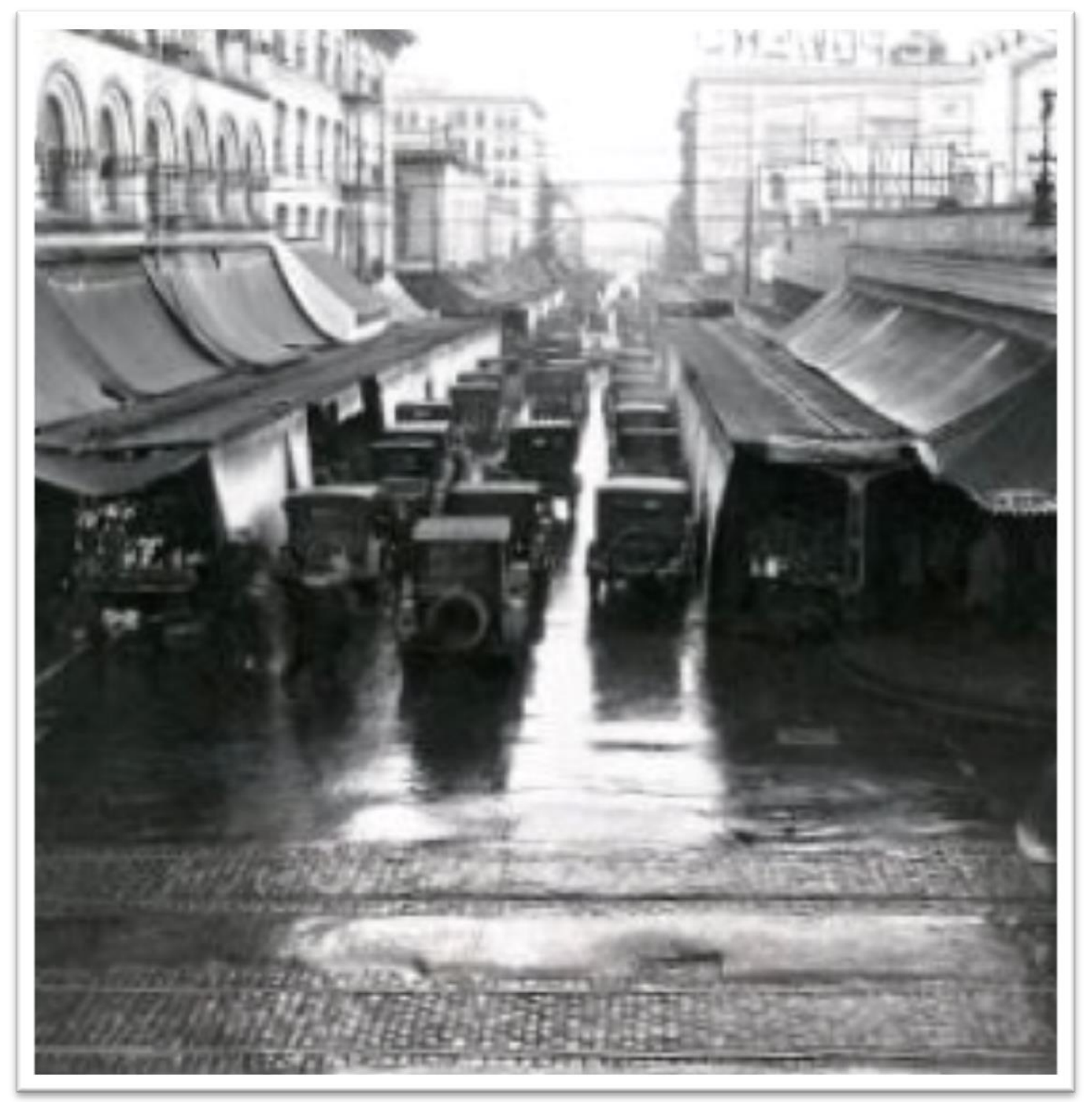

Figure 2 - The Carroll Public Market Street Side ${ }^{79}$

${ }^{79}$ This is a photograph of the Carroll Public Market along Yamhill Street looking eastward toward the waterfront. After several expansions, the addition of the rain covers, and the conversion of every business behind the market to grocery and/or food retail, Yamhill Street became a unique market district that covered four blocks. Producers conducted exchanges with pedestrian and automobile traffic, making the neighborhood a notoriously busy and congested area. "The Carroll Public Market Street Side," ca. 1922-1934?, Oregon Historical Society, Portland, OR. 


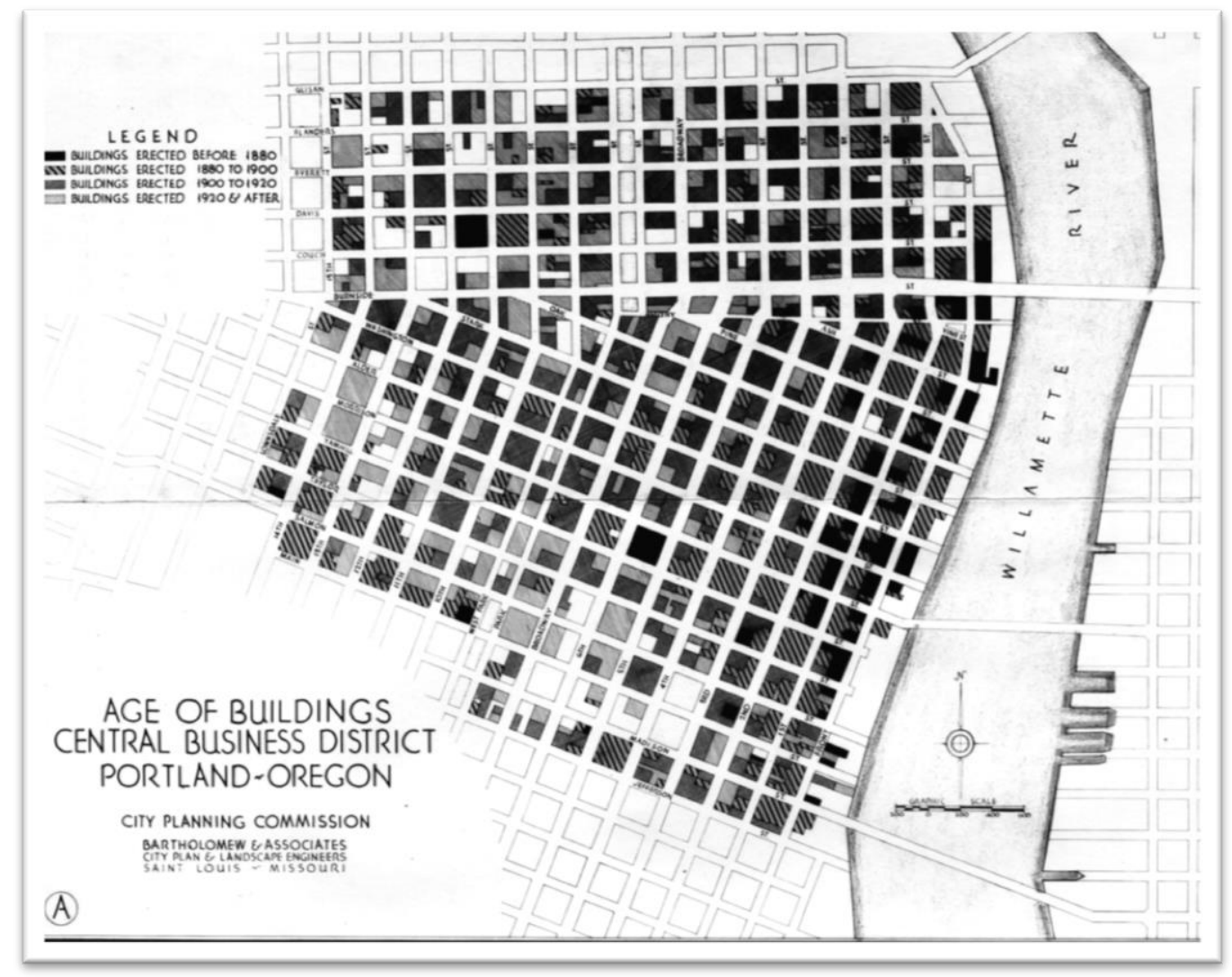

Figure 3-Bartholomew's Map of Downtown Portland 80

\begin{abstract}
${ }^{80}$ The Bartholomew Plan was certainly not the first plan to focus on the central business district (or downtown). Unlike its predecessors, the Bartholomew Plan attempted to understand the movement of what constituted Portland's central business district by studying the age of buildings and the change in property values and businesses over time. This was intended to prevent unanticipated future automobile congestion and allow for managed expansion of the city's business core. City Planning Commission, "Bartholomew's Map of Downtown Portland," ca. 1932, Portland Planning and Sustainability, Historic Maps, http://www.portlandoregon.gov/bps/article/146722, accessed on February 28, 2013.
\end{abstract}




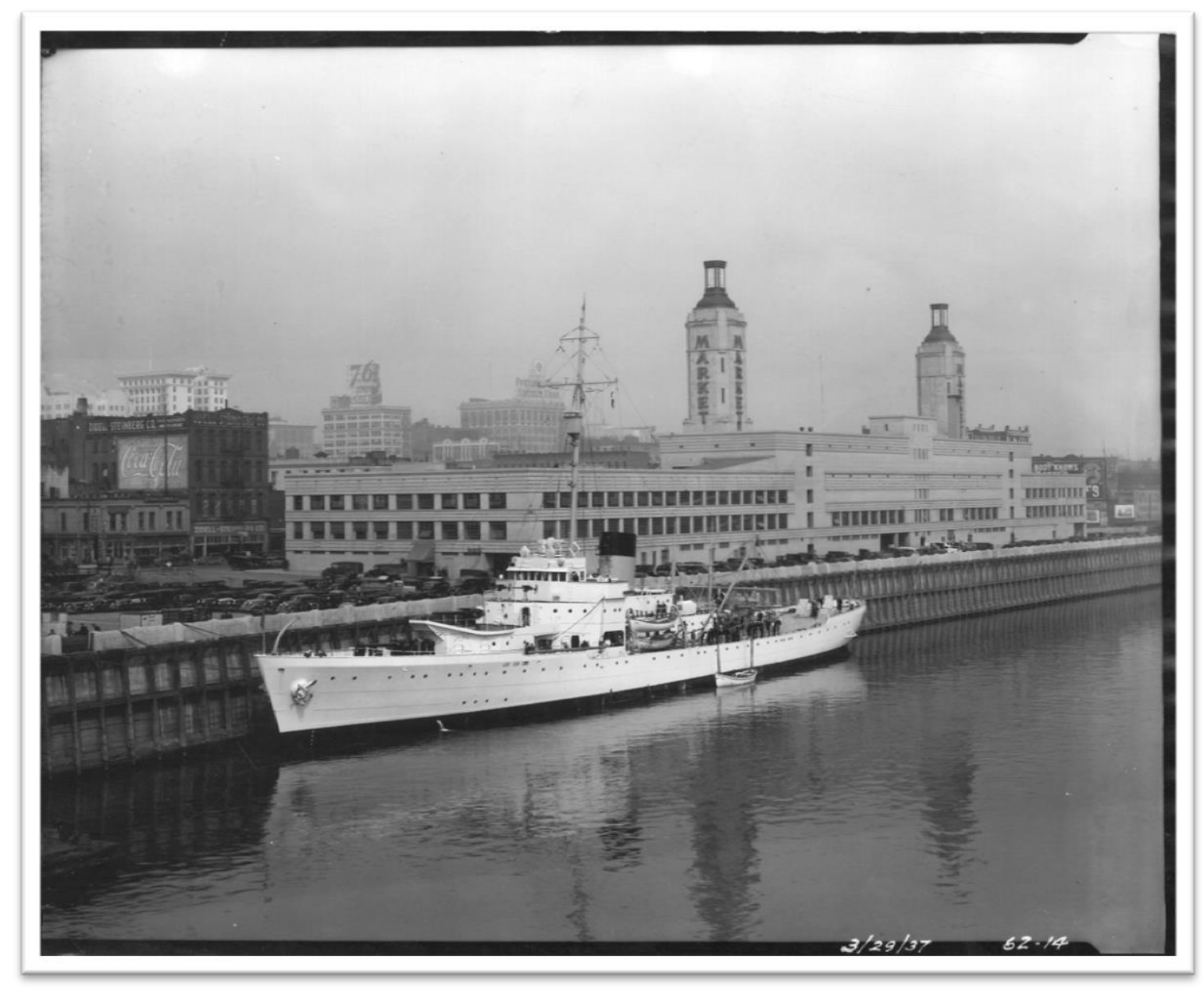

Figure 4 - The Portland Public Market ${ }^{81}$

81 The Portland Public Market really was as large as it laid claim to be. With a forty three million cubic foot interior and enough parking for over six hundred vehicles it was believed that the market would be able to centralize a great deal of retailing and alleviate a large portion of Portland's traffic congestion within the downtown. "The Portland Public Market," ca. 1937, Oregon Historical Society, Portland, OR. 


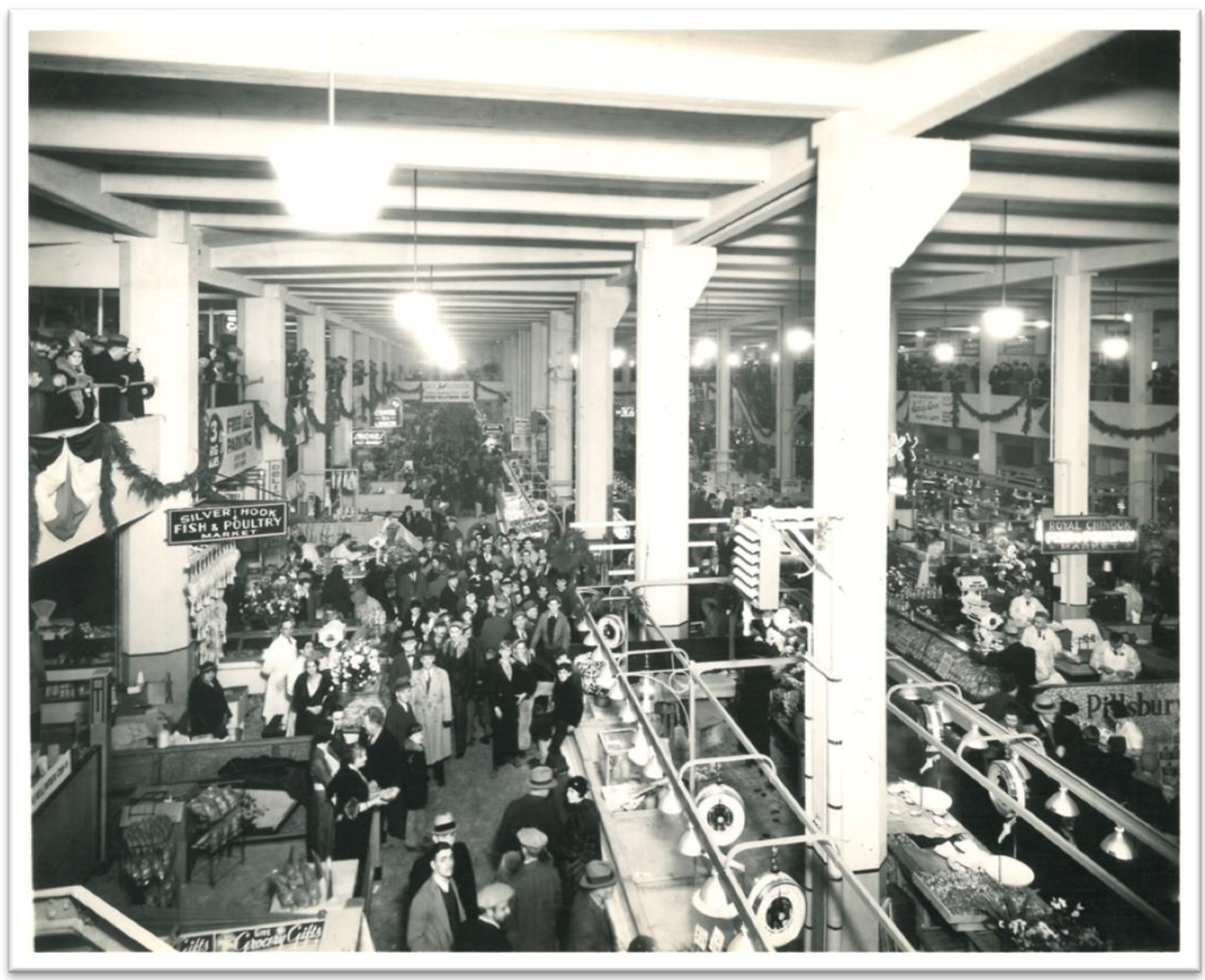

Figure 5 - Inside the Portland's Million Dollar Market ${ }^{82}$

82 Within the Portland Public Market, farmers were a small, if inconsequential, aspect of the greater market. The building was constructed quickly in five months despite the size and technological complexity of the project. "Inside Portland's Million Dollar Market," ca. 1934, Oregon Historical Society, Portland, OR. 


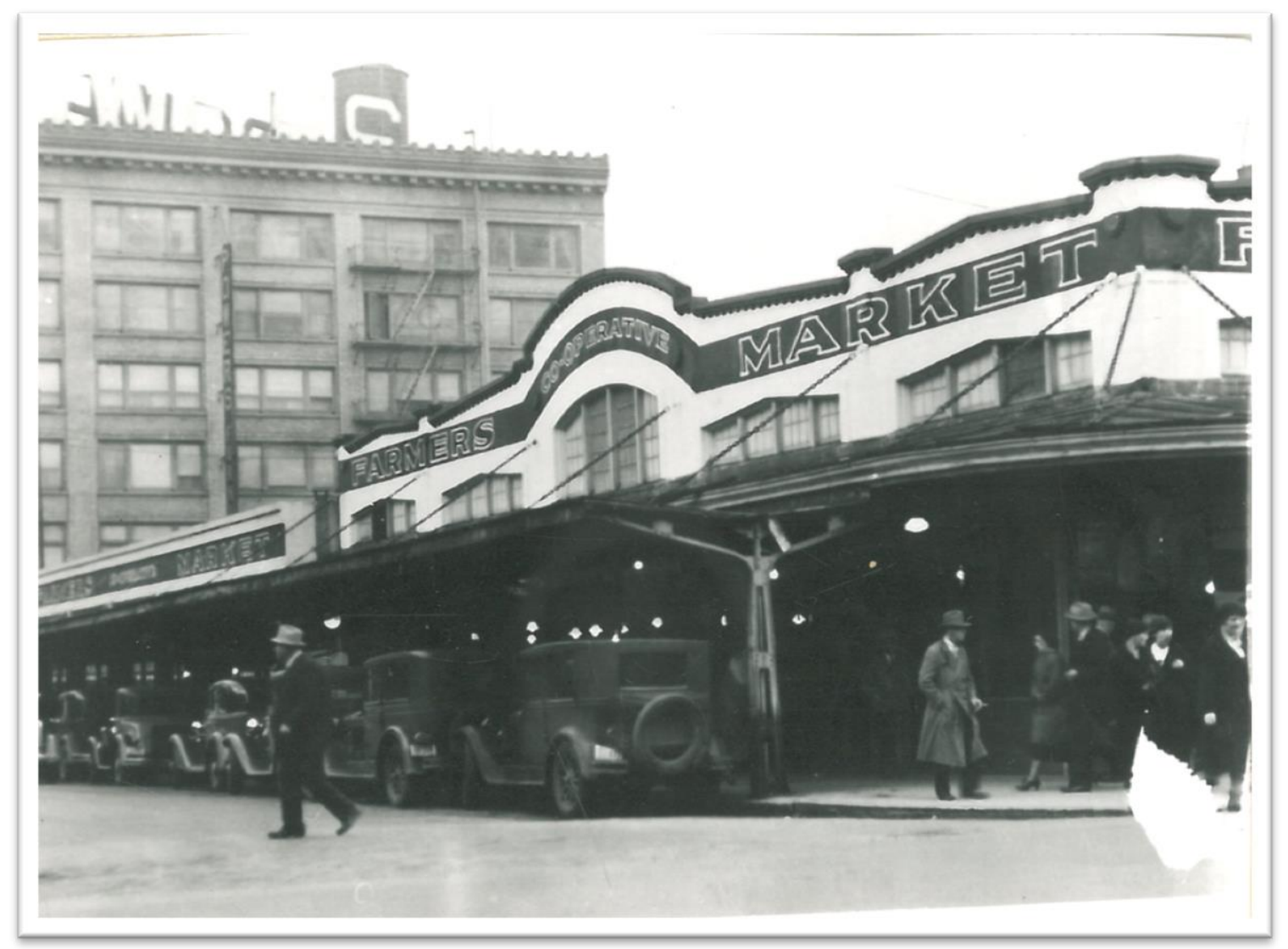

Figure 6 - The Farmers' Cooperative ${ }^{83}$

${ }^{83}$ The Farmers' Cooperative Market was a direct challenge to the Portland Public Market and lasted for roughly fifty years in one form or another. Other business along Yamhill Street that grew up with the Carroll Public Market also remained and supported the Farmers' Co-op. Yamhill Street remained a mixture of private food retailing and farmer's stands for decades before succumbing to downtown development in the second half of the twentieth century. "The Farmers' Cooperative," ca. 1934, Oregon Historical Society, Portland, OR. 


\section{-Chapter 3-}

The Troubles of an Unplanned Market

In the late summer of 1917, Portland's newly elected mayor, George L. Baker, attempted to settle the rising agitation against the Carroll Public Market by assembling an ad hoc group of investigators. ${ }^{1}$ This team was composed of two frequent market goers, Mrs. L. Gee and Mr. J. K. Flynn, as well as a professor from Reed College, Dr. Kelly Rees, who served as chairman. Baker had long supported for the public market and his appreciation of the institution changed little when he took office. ${ }^{2}$ After months of rumors and debate over the effectiveness of the public market to lower produce prices and deliver healthy, wholesome food, Baker had come to the conclusion that while the values and goals of the public market were worthwhile, the institution was having trouble maintaining decent health standards and that management was not providing enough oversight. A loss of faith in the market had begun to occur during the First World War, and critics often pointed to the most tangible piece of evidence to launch other claims: consumer prices.

By October, the team had developed their conclusions into a seven-page report. " $\mathrm{A}$ Public Market thus effectively... managed will inevitably reduce prices for the consumer as well as enable the producer to get more for his profit," it stated, "If the Public Market has failed, its failure is due not to it being a Public Market, but to the manner in which it has

\footnotetext{
1 "Mayor Baker to Mrs. L. Gee," "Mayor Baker to J. K. Flynn," and "Mayor Baker to Professor Kelley Rees," August through September 1917, Correspondence 1914 - P - Public Market, A2000-003, City of Portland Archives, Portland, OR.

${ }^{2}$ Baker served as the city's delegate for Portland's public market convention of 1911. This convention was a cooperative event between rural Grange groups and urban progressive clubs that became a pivotal moment in the creation of the Carroll Public Market. "Move For Public Markets Endorsed," Oregonian. October 11, 1911.
} 
been managed." 3 It was at this point that evolving ideas about the Carroll Market and the public sector's role in city management and planning began to conflict. The commission's analysis of the market's "failures" reflected the values of a changing urban America, one that valued management and planning as the keys to modernization. Conditions at the Carroll Market, including concerns over sanitation, quality of food, and consumer savings were all cited in the report as problems of insufficient management. The commission stated that there was an obvious need for a "thorough house cleaning," and put the relevance of many other concerns to the wayside concluding that, "A COMPETENT ADMINISTRATOR IS

\section{THE ESSENTIAL THING."4}

As Portland grew and its central retail business district became increasingly busier and more consolidated, changes in public policy as well as ideology began to take place. During the 1920s, these developments were primarily an extension of growing support for urban planning. Public officials as well as business leaders believed that planning could offer economic and social stability. Enthusiasts in Portland rallied around multiple goals ranging from residential/commercial zoning to traffic control to large-scale waterfront development. At the heart of many of these transformations stood the automobile, a machine that greatly expanded the productivity and accessible distances of many families. In cities, private and public institutions were forced to accommodate and plan for the abundant automobile (especially so in the central business district). Traffic dominated the concerns of many city planners during the 1920s. As a curbside market, the Carroll Public Market presented a very apparent obstruction to traffic, but there were deeper faults for those that opposed its

\footnotetext{
3 “Commission on Public Market to Mayor Baker," No Date, September or Early October 1917, Carroll Public Market Papers, A2000-004, City of Portland Archives, Portland, OR.

4 "Commission on Public Market to Mayor Baker."
} 
location. Ultimately, the Carroll Public Market was torn down in 1934 because it did not align with modernist trends in city planning and food distribution. Its successor, the Portland Public Market, was dramatically larger, more technologically equipped, and designed for the auto owner.

Modernist ideals about management, health, and efficiency originating in late nineteenth century corporate life influenced a great deal of American cities during the first half of the twentieth century. Historians Carl Abbott and E. Kimbark MacColl have shown that Portland began to focus on these issues during the early 1900s. Within two decades, modernist planning had become an expected and essential aspect of urban governance in the city. Other historians like Gregory Alexander Donofrio have suggested that while issues of quality and inexpensive food distribution were at the heart of initiating modernist notions of planning, they were overrun by a modernist ideology that supported the development of large specialized commercial farms and massive auto-accessible supermarkets. ${ }^{6}$ The objective of modernist planning was to increase the health or well-being of society and cities through better structures of management and more efficient processes of exchange and distribution. ${ }^{7}$

In terms of food distribution, modernism contrasted with older models of distribution because it sought the greatest degree of health and efficiency through management and technology. Institutions like public markets were chaotic and low-tech, and they inherently lacked complex layers of management. The Carroll Public Market conflicted

\footnotetext{
5 Abbott, Portland: Planning, Politics, and Growth in a Twentieth Century City; and MacColl, The Growth of a City: Power and Politics in Portland, Oregon, 1915-1950.

${ }^{6}$ Gregory Alexander Donofrio, "Feeding The City," Gastronomica: The Journal of Food and Culture, Vol. 7, No. 4 (Fall 2007), 30-41.

${ }^{7}$ Alan Trachtenburg has discussed this idea to some extent by exploring the growth of corporate ideology in American life during the late nineteenth century. According to him, the process was rooted in the idolization of the machine and how society could become/or was a reflection of it. Trachtenburg, The Incorporation of America, $38-46$.
} 
with the ideology of modernism in terms of downtown traffic patterns and new technological expectations of food distribution. As the years went on, planners and concerned citizens cast the market as a seemingly non-modern institution unable to compete with the evolving ideals of Portland's downtown developments.

This chapter is divided into two sections: An Obstruction to Modernity, and Planning the Path. The first will discuss the ways in which Portland's downtown district and the Carroll Public Market were increasingly seen as places that needed modern planning and management. Early urban planning was marked by visionary and idealistic notions of development. The second will outline how the movements and plans to correct these problems began to conflict with each other. This divergence eventually encouraged planners to support the development of the Portland Public Market, the largest public market in America during its time and the replacement for the Carroll Public Market. During the 1920s, city planning attempted to ground itself in practical solutions to real problems, ultimately improving the legitimacy and political capacity of planning institutions. The Portland Public Market was advertised with the same modernist rhetoric of these urban planners and even became a central component in their understanding of the future development of the downtown business district. Ultimately, the Carroll Market was seen by many in the planning community as an offense and obstruction to the city's potential.

\section{An Obstruction to Modernity}

Like many of America's cities born in the nineteenth century, Portland's conception of itself as a great metropolis had begun early in development. Nevertheless, it was not until 
the early twentieth century that Portland began to experiment with large-scale planning projects as a path to modern greatness. ${ }^{8}$ These first efforts lacked the practicality of later stages in planning, often rallying around the tenets of the City Beautiful Movement, which Abbott has suggested was meant to "make cities impressive, inspiring, and imperial." City Beautiful also encouraged the creation of civic centers or a centralized district, giving more weight to the physical and symbolic understanding of the central business district or downtown. According to Donofrio, "Beautifying the city was a moral obligation, a civic duty" and while institutions like public markets fulfilled moral responsibilities to producers and consumers through the sale of wholesome food, they often clashed with the movement's other moral ideals like cleanliness. ${ }^{10}$

Portland's first major beautification plan came from John Olmsted, stepson of Frederick Law Olmsted, the architect for New York City's Central Park. Olmsted arrived in Portland in 1903 for purposes of developing a comprehensive park system for the city at the request of Portland's Park Board chairman, Thomas Lamb Elliot. Olmsted's plan was completed and released in June 1904, presenting a city wide, comprehensive park system of playgrounds, neighborhood parks, plazas and green boulevards. ${ }^{11}$ Most notably, the plan consisted of a nearly unbroken greenbelt around and through Portland that signaled a designated city central point. While some of the plan's concepts and ideas were used, it was mostly scrapped due to lack of funds and city council inactivity. In the end, Olmsted gave Portland the blueprints for major improvements like Forest Park, Washington Park, and Mount Tabor, to name a few. Grand, expensive improvements were understandably difficult

8 Abbott, Portland: Planning, Politics, and Growth in a Twentieth Century City, 57.

${ }^{9}$ Abbott, Portland: Planning, Politics, and Growth in a Twentieth Century City, 58.

${ }^{10}$ Donofrio, "Feeding The City," Gastronomica: The Journal of Food and Culture, 30.

${ }^{11}$ Lansing, Portland: People Politics, and Power. 256, 
for many cities to readily accept even if public support was ample. It was not uncommon for plans of this scale to be selectively accepted or picked apart to work with available funds, land, and public backing. In an article from the Oregonian titled, "Is Portland Ready For a Park System," commissioner Ion Lewis summed up the general feelings of supporters and skeptics alike, concluding that the park system "...looks to the future. It may be fifty years before the complete system prepared by him may be procured..."12 It was this notion of looking toward the future with plans to prepare and account for growth that carried on as Portland experienced greater growth over the next seven years.

Support for City Beautiful planning expanded in scope and breadth again in 1909 with the creation of the Civic Improvement League, a one-hundred person committee of private and professional Portlanders. According to Carl Abbott, the league took it upon themselves to hire "an expert to build on the Olmsted report" with the goal of "making a comprehensive plan for the building of a civic center and making Portland an ideal city," as the Oregonian described it. ${ }^{13}$ In 1910, the Civic Improvement League chose architect and city planning visionary, Edward H. Bennett. Previously, Bennett had worked as a partner planner for San Francisco's and then Chicago's city plans, gaining him a reputation for grand scale planning that was in line with the ideals of the City Beautiful Movement. Charged with the task of designing a city for an expected two million people, Bennett took just over a year to complete his design for Greater Portland.

\footnotetext{
12 "Is Portland Ready for A Park System," Oregonian, June 12, 1904.

${ }^{13}$ From Abbott, Portland: Planning Politics, and Growth in a Twentieth Century City, 61. "Purses Open for Beautifying City." Oregonian, November 13, 1909.
} 
The Bennett Plan saw the city as a "living organism" in which the business center was the "heart," the streets were the "arteries," and the parks were the "lungs." ${ }^{14}$ Unlike Olmsted's, Bennett's plan called for a structural understanding of the city of Portland, one that legitimized the business center and designated surrounding satellite neighborhoods in a profound way. Alongside the development of parks, new bridges, a waterfront park, new industrial areas, a cultural district, and a transportation hub, the plan advocated for additional municipal neighborhoods, like suburbs, that ultimately supported the downtown business district. Boulevards and streets stretched out from the "heart" as if such a point truly existed. Bennett even went as far to suggest a new Portland center intersected by Burnside Street and the Park Blocks. According to Abbott, Bennett's plan, "worked outward from the center.",15 Considering Bennett was called to action less than a decade after Olmsted, it is reasonable to assume that support for a comprehensively planned city had gained traction. As a contrast to the reception of the Olmsted Plan, Bennett's was met with wide approval. Even with that degree of support though, the plan lacked the political savvy to be systematically implemented across the board. Coupled with this, Portland's building boom ended in 1913, as the price of wheat dropped and the Northwest was plunged into an economic depression. $^{16}$

The building boom lasted roughly from 1905 to 1913 and has been attributed to the substantial increases in population, expansions in transportation, and development of new

\footnotetext{
${ }^{14}$ City of Portland, Bureau of Planning, "Urban Design Assessment: Central Portland Plan (Section B1: Portland's Great Plans)," http://www.portlandoregon.gov/bps/article/218810, accessed on January 25, 2013.

15 Abbott, Portland: Planning Politics, and Growth in a Twentieth Century City, 63.

16 The only implementation of the plan was completed through the establishment of the Commission of Public Docks which secured funds prior to the depression. Their goal was to increase "independent river trade or coastal traffic" in an effort to "loosen the tight grip of the railroads." Abbott, Portland: Planning Politics, and Growth in a Twentieth Century City, 67.
} 
industry machine jobs. ${ }^{17}$ Bank transactions increased by one hundred and fifty percent and employment growth outpaced population. The depression sharply ended one of Portland's most prosperous periods and as a result, government spending dropped in response. With city spending dropping from seven million dollars in 1911 to roughly six hundred thousand in 1916, there was not any room for the grandness of Bennett's "Greater Portland Plan." While the idea of planning a modern city gained ground in the minds of Portlanders as well as city council members, many were forced to reevaluate their assumptions about growth, as the automobile increasingly became a significant feature of the American urban environment. Of Bennett's plan, city commissioner Ormond Bean later asserted, "It was a general and visionary plan of the development of the city as a whole with no thought of the practical carrying out of the exact plan. It was logical in its general conclusions but needed more careful engineering study in details." 18 was this lack of "practical carrying out" that plagued the City Beautiful Movement in Portland. The concept of city planning moved forward and adapt though. In Portland, planning became a serious and practical endeavor just prior to the 1920s, as many of the problems that had been perceived by the City Beautiful Movement as well as the unexpected ones, like the popularity of the automobile, began to cause duress. During the same time, the Carroll Public Market found itself both literately and figuratively grappling with these issues.

As mentioned earlier, price appeared to be a point of contention at the market that could not be permanently resolved. Groups like the Fair Price Committee, between 1917 and 1921, illustrated one of the many conflicts between a modernizing society and traditional

17 Abbott, Portland: Planning Politics, and Growth in a Twentieth Century City. 50-51.

${ }^{18}$ From MacColl, The Growth of a City: Power and Politics in Portland, Oregon, 1915-1950: Letter of Ormond Bean to F. M. Byan, July 1, 1935, Ormond Beam Papers, Oregon Historical Society, Portland, OR. 
food distribution systems. As Tracy Deutsch has illustrated in Building a Housewife's Paradise, American grocery consumerism on both sides of the exchange began to focus on price increasingly in the early twentieth century. ${ }^{19}$ Major organized attempts to lower prices began during World War I, when food prices skyrocketed. On average, Americans were paying twice as much for "rent, food, clothing, and other living costs" in 1920 than they did in 1913. ${ }^{20}$ Yearly, daily, and even hourly fluctuations in price were all cause for heightened levels of distrust and frustration in a country that increasingly expected and enacted standardization and reliability. Not surprisingly, it was at this time that chain stores started to enter the arena of American grocery. While there was considerable and various forms of backlash, the first chain stores paved the way for the larger supermarkets during the 1930s, a closely relatable model to the Carroll Public Market's replacement, the Portland Public Market. For the supermarket, price could be brought lower, gratifying expectations that they could be lowered more regularly. ${ }^{21}$

As new consumer values gave rise to chain grocery stores that had the capacity to dramatically lower prices and present the shopper with a controlled environment, food distribution throughout the country began to change. Public markets could keep prices low, but they were often more unpredictable than those of the grocery store because of the nature in which they operated. With a wide variety of vendors and customs for exchange present in one building, they lacked the standardized service that grocery stores advertised. Public markets throughout the country consisted of merchants and producers from a wide collection of ethnic groups, social classes, and political organizations. In 1918, many older

\footnotetext{
${ }^{19}$ Deutsch, Building a Housewife's Paradise: Gender, Politics, and American Grocery Stores in the Twentieth Century, 43-49. ${ }^{20}$ Deutsch, Building a Housewife's Paradise: Gender, Politics, and American Grocery Stores in the Twentieth Century, 45.

${ }^{21}$ Deutsch, Building a Housewife's Paradise: Gender, Politics, and American Grocery Stores in the Twentieth Century, 169171.
} 
and larger cities than Portland operated multiple markets that catered to different levels of producers and consumers. New Orleans operated nineteen open air and "inclosed" (permanent indoor building) markets within the city limits where stall rentals ranged from fifteen cents a day to three dollars and fifty cents a day depending on the location, products, and vendor. ${ }^{22}$ This stratification broadened support as well as attracting more attention.

As a government and cultural institution, the market was subject to democratic scrutiny in which commissioners and occasionally mayors were liable to the public's concerns. Inflation during World War I signaled the evolution of consumer expectations as well as temporarily reinvigorating the local support given to the Carroll Public Market. Following the war, price increasingly became the focus of consumers' attention. As consumers sought lower costs, public markets across the country experienced a renewed interest. New attention was not all good; high prices and inflation "intensified the long standing politics of food stores, exacerbating preexisting social tensions." ${ }^{23}$

During the early 1920s, the Carroll Public Market attracted the attention of groups like the Oregon Federation of Fraternal Societies (OFFS), a nativist assembly that concerned itself primarily with the employment of white American citizens over foreign aliens. Racial fears began at the onset of the market though, and Commissioner Bigelow often ordered investigations after complaints were made against certain groups. In 1915, the Thief Detective Service Company reported to him that investigations had shown that Japanese vendors were "living up rather strictly to the market ordinance." Over the years though, the changing political environment of Portland and Oregon increased the need to make

\footnotetext{
${ }^{22}$ New Orleans had by far the most public markets of any city in the United States during the twentieth century. U. S. Bureau of Census, "Municipal Markets in Cities Having A Population of Over 30,000: 1918," Prepared by Sam L. Rogers, Washington, DC: Government Printing Office, 1919.

${ }^{23}$ Deutsch, Building a Housewife's Paradise: Gender, Politics, and American Grocery Stores in the Twentieth Century, 45-46.
} 
adjustments for some of the vendors. The election of 1918 in Portland was greatly

influenced by groups similar to OFFS like the American Patriotic League, the American Patriotic Association, and the Oregon Federation of Patriotic Societies. ${ }^{24}$ In response to the political clout of nativist individuals and groups, Bigelow felt compelled to do something and in 1920 organized the stalls by ethnic clusters. Small groups of Japanese and Chinese vendors were alternated from First Street until halfway past Second Street. "So-called-White farmers," as Bigelow called them, were placed in some of the most preferred market space on the north side of the street from Third until Fifth with Italian farmers occupying the south side. ${ }^{25}$ Instead of branding the market as a place solely for white citizens as some interests wanted, Bigelow composed a solution to satisfy nativist reactions within his understanding of the public market. This resolution resulted in removing the Japanese and Chinese vendors from choicer locations along Yamhill, but it also prevented a revision of the market's identity as a racially exclusive institution.

Nativist sentiment did not always result in such a direct attack on the positioning or existence of non-“white” ethnic groups. On February 3, 1930, C. B. Woodworth, a concerned citizen, wrote to Bigelow to complain of "the greeks [who] bawl out their wares from morning until night. They are insulting to those who do not purchase and they are cheats." ${ }^{26}$ Several years earlier, due to consumer complaints, the city had outlawed the calling out of wares by vendors. More often than not, these statements were racially charged. Woodworth expressed his fears in similar fashion by adding that "They do not understand

\footnotetext{
${ }^{24}$ MacColl, The Growth of a City: Power and Politics in Portland, Oregon, 1915-1950, 154-155.

25 "Bigelow to J.A. Eastman on Vendor Organization, August 22, 1920, Carroll Public Market Papers, A2000004, City of Portland Archives, Portland, OR. 26 "Woodworth to Bigelow," February 3, 1930, Carroll Public Market Papers, A2000-004, City of Portland Archives, Portland, OR.
} 
anything but force, no good to warn them, it will avail nothing, they will keep on. Suppose that everyone on the market did the same thing, it was impossible to trade there." ${ }^{27}$ It should be understood that while Woodworth's comments speak to larger questions concerning race, he expressed those feelings within his desires for a managed environment, one that allowed "trade" to occur without distraction. The chaos of older food distribution institutions became increasingly less desirable as the twentieth century marched on. ${ }^{28}$

Racialized attacks on the market did not always end in dissatisfaction at the Carroll Market. Nine days after sending his initial letter, Woodworth contacted Bigelow once again; but this time to apologize. After discovering that not every stand at the market was "run by greeks," Woodworth remarked that "It was not my intention in the letter to cast any reflection on the greeks as a nation... now I find that the greeks near the market are more courteous than the rest of them and more quiet." ${ }^{29}$ Woodworth's rapid reversal highlight the degree of suspicion that had come to characterize the seemingly disordered nature of the market as well as the grey and often shifting lines of color. While the public market served as a place of opportunity for many immigrants in Portland, it was also their presence that helped to muddle public opinion and perception of the institution's integrity.

\footnotetext{
27 "Woodworth to Bigelow."

28 The history of the rise of chain grocery stores during the 1920s and 1930s is one of the best ways to understand the changing consumer demands of American food shopping during the early twentieth century. As Tracy Deutsch has shown, price was an important component of chain groceries rise to power but they "also succeeded because of their promises of modernity, independence, and equality for women shoppers." To be clear, larger bureaucratic institutions of food distribution did not win over the hearts and minds of consumers easily or quickly. Between 1914 and 1945, the anti-chain movement, multiple reinvigorations of public market support, and the growth of food cooperatives served as responses to growing corporate and anti-local institutions attempting to dominate cities' food distribution. These institutions left little room for the presence of immigrants in positions of power or management, encouraging the promulgation of neighborhood groceries for ethnic communities not unlike the former groceries. Deutsch, Building a Housewife's Paradise: Gender, Politics, and American Grocery Stores in the Twentieth Century, 43.

29 "Woodworth follow-up to Bigelow," February 12, 1930, Carroll Public Market Papers, A2000-004, City of Portland Archives, Portland, OR.
} 
Sounds and prices were not the only aspects of the market subject to critique. As mentioned earlier, sanitation and public health became primary concerns of many consumers. The visual appearance of rotten food and swirling flies prompted early attacks against the market demanding that the place be cleaned up. In order to satisfy new regulations in food safety and ensure quality, Market Master J. A. Eastman was trained and certified in 1918 as a deputy by the state's Dairy and Food Commissioner, J. D. Mickle. ${ }^{30}$ By 1928, Bigelow had even hired Mrs. Sarah Evans as Market Inspector to act as an intermediary between consumers and producers. ${ }^{31}$ Evans concerned herself primarily with keeping up the sanitary conditions of the market and enforcing rules on proper covering, refrigeration, and removal of food. By the early 1920s, Bigelow had implemented a regular garbage pickup, regulated vendor's waste disposal, and installed a drainage system. Throughout the decade, the market was seen as a force of good health in Portland. Evelyn Spencer, a former research specialist for the United States Bureau of Fisheries in Washington State, commented on the contrast of the Yamhill Market to older eastern markets, "Portland can hold its head high," he stated in comparison with fish in eastern markets that were "flabby, with sunken eyes, and dull gills." "I can talk about eating fish for health here in Portland without feeling a blush of shame," he added. ${ }^{32}$

The frequency of high praise for the market's contribution to public health during the 1920s is not to be understated, but as the years drew closer to the establishment of the Portland Public Market, the Carroll Market began to be cast as a backward, unsanitary, mess. These opinions were further legitimized in October 1931, when the plans for the Portland

\footnotetext{
30 “Mickle to Bigelow Concerning Eastman,” February 27, 1918, Carroll Public Market Papers, A2000-004, City of Portland Archives, Portland, OR.

${ }^{31}$ Evelyn Spencer, "Food Markets in City of Highest Standard," Oregonian, March 8, 1928.

32 Spencer, "Food Markets in City of Highest Standard."
} 
Public Market were initially approved by the city council. To heighten the immediacy of the need, the council attached an emergency clause stating the following:

Inasmuch as the ordinance is necessary for the immediate preservation of the public health, peace, and safety of the city of Portland, in this: Owing to the general demand for a modern public market and the immediate construction thereof, [for unemployment assistance and traffic congestion relief]... an emergency is hereby declared to exist and this ordinance shall be its force and effect... ${ }^{33}$

As a "threat," the Carroll Market could be contrasted easily with the expectations of a newer and more "modern" institution. While the market along Yamhill was able to evolve out of higher governmental and consumer expectations of health and safe food handling, it would not be able to compete in those arenas against an establishment that was intended to be technologically advanced. Ultimately though, debates over the "health" of Carroll Market took a backseat to real, incurable issues of traffic congestion.

No other technological advance during the first half of the twentieth century bolstered the role and intention of city planning more than the automobile. ${ }^{34}$ According to Carl Abbott, "Portland planners were hostages to the automobile between 1920 and 1940, and the working definition of their job changed from urban design to traffic engineering." 35 The car had countless other effects on American society that are beyond the scope of this thesis, including dramatically altering the potentials of urban, state, and national food distribution. Auto enthusiasm and need grew rapidly in Portland during the 1920s and by 1929 , Portlanders "spent as much on their autos as they did on their food-- $\$ 42$ million to buy new cars and keep them running. ${ }^{, 36}$ Due to its location within the central business district, the curbside Yamhill Market was subject to some of the densest areas of vehicle,

\footnotetext{
33 "Way to Market Paved," Oregonian, October 11, 1931.

${ }^{34}$ Fogelson, Downtown: Its Rise and Fall, 1880-1950, 252-255.

35 Abbott, Portland: Planning Politics, and Growth in a Twentieth Century City, 122.

36 Abbott, Portland: Planning Politics, and Growth in a Twentieth Century City, 93.
} 
pedestrian, and streetcar traffic in the city. ${ }^{37}$ It was not an innocent bystander either; with over seventy thousand producers attending each year as well as consumers seeking to buy at either the market or the privately owned stores behind it. It is not surprising that Yamhill Street became a traffic trap. The fact remained that if the city was determined to commit to the automobile business could not be conducted on the street in the downtown area. Above all other potential pitfalls, traffic became the insolvable problem of the Yamhill Market.

Between 1926 and 1934, the debate over the future of the city's public market came to fruition, as the divide between supporters for the old and new market grew wider. While nearly all could agree that a plan was needed, city planners overwhelmingly supported the installation of a “modernized” market. In the City Planning Commission’s June 1929 edition of "The Plan-It," an advisory newsletter to the mayor and city council, the group stated the following:

\begin{abstract}
The present use of Yamhill Street for market purposes is unsightly and uneconomical and wholly inadequate for the public convenience. To visitor from other cities...the market on Yamhill Street gives the impression of a country village, indifferent to appearances and to the convenience and accommodation of the public. Portland has long since outgrown such use of Yamhill Street... ${ }^{38}$

While rhetoric from the Planning Commission was certainly some of the most inflammatory, it was not far off from the views of many city planners who saw the automobile as the catalyst for the modernization of Portland. During an era of increased expectations for and from city planning, the market became increasingly perceived as a physical and ideological obstruction to modernity. For planners, the market as it stood was incapable of improving its health or efficiency to meet new standards. The plan for the Portland Public Market attempted to consolidate a massive amount of Portland's food
\end{abstract}

\footnotetext{
${ }^{37}$ MacColl, The Growth of a City: Power and Politics in Portland, Oregon 1915-1950, 293-295.

38 City Planning Commission of Portland, "The Plan-It," June 1929, Portland Planning Commission Papers,
} City of Portland Archives, Portland, OR. 
distribution in one building, out of the way of the downtown, and on the river near the center of the city's commerce and transportation. It was idealistic, but many believed that its embrace of modernism would sustain the institution.

Planning the Path

In the years following Edward Bennett's grand yet unfulfilled plan for Portland, city planners nationwide began to reject former ideological tendencies in exchange for a new focus on efficiency and practicality. City Beautiful became City Scientific (or City Practical). ${ }^{39}$ As city planners worked to legitimize their work during the 1910s, the military needs of World War I created immediate opportunity for planning and demand for housing, as many cities across the country saw a massive influx of workers for war-time construction. Portland's ship construction created thirty thousand industrial jobs between 1916 and 1918 and a very real need to stabilize the economic and social effects of this new population on the existing community. Charles Cheney, secretary of the California Conference on City Planning, was hired by the city of Portland in 1917 to act as a consultant for the city's war housing problems. Cheney believed that the new doctrines of urban planning contrasted sharply with the City Beautiful Movement; "While splendid studies of Portland and other cities were made," he stated, "their effect was largely the same as shooting into the air...these splendid early civic efforts went beside the mark and were largely wasted." ${ }^{40}$

\footnotetext{
39 Abbott, Portland: Planning Politics, and Growth in a Twentieth Century City, 71-72.

${ }^{40}$ From Abbott, Portland: Planning Politics, and Growth in a Twentieth Century City, 71: "Correspondence Charles Cheney to George Baker," August 27 1918. Several years later, Cheney's final city planning report noted "We have adopted as much of the old plans as we still found practical and really added very little that is new, except a few important readjustments to handle the enormous new traffic problems developed with the last decade."
} 
Offering himself up as the rationalized equivalent of previous planners, Cheney was widely supported by the Portland business community, many city council members, and Mayor Baker. The housing crisis, not unlike the emergence of the automobile, encouraged a commitment to city planning, private and public interests had much to lose from a nonfunctioning gridlocked downtown or unforeseen neighborhood expansion.

Cheney would not submit his comprehensive plan until 1921, but during his years in Portland he acted as a planning consultant, ultimately sponsoring one of the city's first major pieces of city planning legislation: zoning. According to Cheney, zoning was "the first fundamental step in any city to establish a practical basis for constructive city growth." ${ }^{\not 1}$ Cheney's ordinance passed in 1920, one year after the creation of Portland's City Planning Commission. Due to anti-zoning campaigns, the measure was repealed and then redrafted for approval in $1924{ }^{42}$ Zoning had the effect of specifying neighborhoods as well as legally securing property investments, not unlike the similar process that had started nearly fifty years prior as wealthy Portlanders used their capital to secure the location for the central business district. Cheney's success with zoning created a launch pad for future city planning endeavors, giving the city's planners and council members good reason to believe in the necessity and potential of modern planning. Even though Cheney's greater plan was not immediately adopted, it directed attention at the automobile and set the tone for future planning in Portland. ${ }^{43}$ While it was some time before Cheney had other significant effects on the layout of the city, it was his plan that influenced the development of new downtown

City Planning Commission with Charles Cheney, "Major Traffic Street Plan Boulevard and Park System for Portland, Oregon," January 1921, City of Portland Archives.

${ }^{41}$ MacColl, The Growth of a City: Power and Politics in Portland, Oregon 1915-1950, 297.

42 Abbott, Portland: Planning Politics, and Growth in a Twentieth Century City, 86-87.

43 Abbott, Portland: Planning Politics, and Growth in a Twentieth Century City, 92. 
bridges (Burnside Bridge) and street-widening, including crucial arterial constructions for stabilizing downtown centers of traffic and preventing the retail core from moving. ${ }^{44}$

At the time, zoning laws appeared to have no effect on the Carroll Public Market, but in reality they started a process of block-by-block predetermination that made it increasingly difficult for the market to continue along the curbside. Surprisingly, while Cheney's completed plan in 1921 was the first to suggest a renewed focus on the effects of the automobile, it did not advise a complete removal of operations along Yamhill. Instead, Cheney suggested that the market should be shifted to a location that had more options for transportation, because it was easier for the farmers as well as the consumers to participate in the exchange as the report stated,

It will probably be found advisable, however, to continue the retail market up Yamhill Street at least as far as Fourth Street. A considerable part of the success of this market is undoubtedly due to its present location immediately adjoining the retail business center of the city. Removed entirely to the waterfront east of Front Street, it would not have the same success or attract near as much trade as it has at present. ${ }^{45}$

Unlike his predecessors or successors, Cheney envisioned the waterfront as the center of the city's "interurban depot," a place that could offer multiple transfers of transportation, an ideal foot- traffic location for public market trade. Cheney, though, was one of the first planning consultants to suggest a built-up waterfront, an idea that gained momentum in the following years.

Two years after the Cheney report, City Engineer Olaf Laurgaard proposed a waterfront plan that set in motion the undoing of the Carroll Public Market. Over the course of Portland's history, the waterfront was one of the most debated spaces between public and private ownership. Laurgaard's plan opened the debate again with the proposal of a seawall

${ }^{44}$ MacColl, The Growth of a City: Power and Politics in Portland, Oregon 1915-1950, 321-322.

${ }^{45}$ City Planning Commission with Charles Cheney, "Major Traffic Street Plan Boulevard and Park System for Portland, Oregon,” January 1921, City of Portland Archives, 47. 
that would extend and level the usable land along the river. Borrowing from Cheney, Laurgaard also recommended the use of train and other transportation depots to centralize the space, but rather than extending the existing public market, Laurgaard suggested the creation of a large waterfront market building to replace Yamhill's. The plan also met with wide approval, but only the seawall and sewer system were directly implemented. They were completed in $1929 .{ }^{46}$ As space began to materialize along the waterfront, speculation about the potential of a larger public market centerpiece gained significant traction. By 1926, Yamhill Market had lost much of its autonomy as an institution. With over a decade of various social and political struggles, increasingly complicated traffic congestion problems, and the emergence of modernist city planning, the Market had gained a base of opposition. The waterfront public market plan gained ground over the 1920s, because it could absolve itself from the obstructions Yamhill had come to represent. In the end though, arguments over the creation of a new market really hinged on location. Yamhill Market supporters associated themselves with the downtown commercial environment, while many city planners saw the waterfront market as the catalytic agent of a new commercial environment. Prior to the final extension of the market along Yamhill, Commissioner Bigelow had sought the advice of Portland's Inspector of Buildings from the Department of Public Works. The report, submitted in November 1919, was the first formal plan to speculate about the importance of location and the possibility of reconstructing the market. ${ }^{47}$ Three potential plans were delivered: the first opted for a cheap curbside addition along Taylor (a

\footnotetext{
${ }^{46}$ MacColl, The Growth of a City: Power and Politics in Portland, Oregon 1915-1950, 315-321.

${ }^{47}$ Earlier suggestions came from housewives groups who declared the market needed to be moved into a full block institution because of sanitation concerns. H. E. Plummer? to Commissioner Bigelow: Market Projections, November 15, 1919, Carroll Public Market Papers, A2000-004, City of Portland Archives, Portland, OR.
} 
parallel street); the second recommended the city's acquisition of the Corbett and Failing blocks (between Yamhill, Taylor and Salmon, and bounded by Fifth and Sixth streets) for the fairly expensive (one and a quarter million dollar estimate) construction of a permanent market building; and the final plan suggested a continuation along Yamhill Street. The Inspector was careful to note that the construction of a public market building in the heart of the business district might not be economically viable, but the plan moved in the direction of permanence and centrality that was more desirable. It appears obvious why Bigelow decided to continue along Yamhill; according to the report, remaining on the same street was cheaper, for it allowed for an organic development in a "series of steps" and it moved toward the cheaper waterfront property. ${ }^{48}$

While it is not clear as to the specifics of the team working on this report, it did come from Olaf Laurgaard's department during the same time he created his vision for the seawall. The report's third option described an evolution of the Carroll Public Market as it spilled onto the waterfront, growing into a larger more capable institution, and eventually becoming housed in a permanent building. Ultimately, Bigelow chose to expand the market step by step, and for some time this fit well with the push and pull of consumer and political attitudes, as well as the uncertain and slow development of the downtown. Unfortunately, it was this process that also made Yamhill an opposing force when the city began to commit to modern planning and the possibilities of waterfront development. As consumers and producers became increasingly attached to the location and the idea of the market as a downtown institution, it became difficult for supporters to appreciate a waterfront public

48 “H. E. Plummer? to Commissioner Bigelow: Market Projections, November 15, 1919, Carroll Public Market Papers, A2000-004, City of Portland Archives, Portland, OR. 
market, especially one that was developed by a private entity that had no desire to coordinate with existing members of the Carroll Public Market,

As construction brought Laurgaard's waterfront plan into reality, the idea of a waterfront market also began to take shape. As early as 1926, rumors had begun to circulate in the Oregonian that a group of private investors were interested in building Laurgaard's waterfront centerpiece. "Parts of Chinatown and numerous Rat-Infested Structures of Bygone Days to Make Way for Modern Development to Include Street Widening, Seawall, Docks and Public Market Building in Their Stead," the Oregonian's headline read. ${ }^{49}$ The investor group later referred to themselves as the Public Market Company of Portland and their project as "An opportunity for a safe, profitable investment in a Semi-Public Institution.. ${ }^{, 50}$ By 1927, the company had become incorporated and had drawn up an initial pamphlet for investor meetings to showcase plans, costs, and expected profits. The plan certainly looked to be a good investment; waterfront property was cheap (a problem that plagued alternatives in later years) and the Carroll Market's traffic congestion worsened by the year. While a notable feature of the plan was the rooftop parking for roughly four hundred cars, the rhetoric as to "Portland's Need" and "The Solution" in the company's promotional pamphlet gave away the deeper ideological motivations for a predictable and organized market that was structured under the greater vision for Portland's downtown.

[Portland's Need] That there is a need for a modern, sanitary, convenient market has been evident for some time. The farmers' stalls in the Yamhill Street market are crude affairs without convenient, adequate or entirely sanitary storage facilities, and the buildings housing the other market

\footnotetext{
49 The article also noted that the public market would hold space for "thousands of automobiles" and according to Laurgaard, "That feature alone would do much to solve the traffic congestion." This was grossly inaccurate as the institution held considerably less than a thousand cars. "Waterfront Way to get New Life," Oregonian, August 15, 1926.

50 Public Market Company of Portland, "Public Market Promotional and Investment Pamphlet," June 1927, Carroll Public Market Papers, A2000-004, City of Portland Archives, Portland, OR.
} 
activities are old and poorly arranged on account of not having been originally designed for market purposes.

[The Solution] It has been agreed that a main downtown street could not continue to be congested as Yamhill is, and that more modern, sanitary conditions must be provided for the handling of food stuffs...plans have been completed for this long hoped for development. ${ }^{51}$

The pamphlet suggested a need for modernity, criticizing Yamhill (the market and business owners) for its lack of planning and dated structure. Such rhetoric offered clear ignorance and/or lack of appreciation for the organic process that had occurred along the street. The idea of a new market had gained momentum by this time though, and was initially approved in 1930. Not surprisingly, the Carroll Market's community and city council supporters launched a sizable defense, ultimately prolonging construction of the new “modern” market until the first of January 1934.

Between 1928 and 1933, Portland's city council had trouble finding consensus for the plans of the Public Market Company. During these years, considerable suspicion was directed at the city council's supporters of the new market and when approval did come, many suspected that powerful interests had bought their votes. ${ }^{52}$ Whether or not this was the case, a cultural shift had occurred in Portland's government that muddied the underlying value of new "civic" institutions. The new Portland Public Market represented a next step in the city's future a modern urban environment made efficient and practical by planning.

In 1932, Harlan Bartholomew published the most detailed and comprehensive city plan to date in Portland's history. The plan was almost entirely structured around creating a compromise between efficient automobile traffic systems and maintaining complimentary public spaces. While the Bartholomew Plan was known for its professional scope, it became one of the least influential plans in Portland's history because of one major conflict--the

\footnotetext{
51 Public Market Company of Portland, "Public Market Promotional and Investment Pamphlet."

52 MacColl, The Growth of a City: Power and Politics in Portland, Oregon 1915-1950, 492.
} 
waterfront. By 1932, agreements and plans for the Portland Public Market were essentially complete. Laurgaard and other investors' dreams of a waterfront extension of the downtown business district had gained critical momentum, and no matter how producers, consumers, or other council members opposed the new market, it seemed impossible to break the momentum. Bartholomew envisioned a civic waterfront: public plazas, parks, and an underground parking garage to avoid unsightly droves of cars. This idea of a public waterfront was first conceptualized by urban leaders around the time of Portland's founding and later became a reality in the 1970s.

Planning had become a seemingly necessary aspect of urban management in Portland during the 1920s and rightfully so; the economic, social, and cultural impact of the automobile could not have been foreseen by anyone. The righteousness of groups like the City Planning Commission were certainly not unique to Portland and it was their defense of planning and the centrality of the automobile that dismantled much of the older infrastructures of transportation and individual downtown experience. During the Portland Public Market's first year of operation, the July 1934 edition of "Plan-It" the commission concluded, "Traffic is the greatest source of inconvenience of the business area of a modern city. The loss of time, the actual damage to property, the casualties caused by the effect...” adding, "- - these things cannot be accurately or quantitatively measure, but it is certain that the total is enormous." ${ }^{53}$ They were so sure of themselves that real data had almost ceased to matter. And it was with this fanaticism that they proposed and advocated for automobilesensitive development throughout the city. In reference to the downtown they affirmed,

53 City Planning Commission of Portland, “The Plan-It.” July 1934, Portland Planning Commission Papers, City of Portland Archives, Portland, OR. 
"Build one section of one city to fit the automobile, and there will be an immediate nationwide demand for the same thing in every city."

The car had also aided in shifting consumer values of food distribution that had been initiated by debates over price, modern technologies, and modern expectations of efficiency. In Portland this was undoubtedly shown as a contrasting between the Yamhill Market and the Portland Public Market. For many Portlanders though, this difference (or lack of modernity) was not a bad thing. The Carroll Public Market remained meaningful to many Portlanders as the city's food distribution systems changed and its ideals came to be used as a rallying point for those who enlisted themselves within its cultural foundation. 


\section{-Chapter 4-}

The World's Most Modern Food and Merchandise Mart

In 1933, two days before Christmas and eight days before the end of the Carroll Public Market, twenty eight Yamhill Street merchants reassured Portland in an ad that read "Notice to the Public: We Are Not Moving!" With the date set for demolition of the market sheds, it appeared to many that the attraction was on its way out. Over the course of twenty years, nearly every store behind the market had been converted into food or grocery sales, an incredible fact considering there was never a formalized incentive. It is easy to acknowledge that these merchants were concerned about their own investments over those of the farmers, but it should also be recognized that many of them belonged to a commercial community with the farmers of the old market that had existed for over a decade. Some of the merchants had been there for over fifteen years and owed a lot of pedestrian traffic to the Carroll Market.

While the record is scarce on the operations of these Yamhill merchants, it is known that many had the opportunity to move into the new waterfront market and chose not to. They had become dedicated to their location and their community. Some merchants like Fred G. Meyer considered the complete demolition of the market to be slightly excessive, suggesting that at least the sheds (a distinct reminder and addition to the market) be kept to keep customers out of the rain. ${ }^{2}$ The shop owners even circulated a petition hoping to use the power of collective voice to stop the destruction. By this point in the waterfront market campaign, it had become clear that the Public Market Company settled for nothing less than

\footnotetext{
1 "Notice to the Public: We Are Not Moving," The Oregonian, December 23, 1933.
}

2 "Market Sheds Wanted," The Oregonian, December 14, 1933. 
the absolute elimination of the Carroll Public Market. On January 1, 1934, the termination was completed and the sheds and tarps were torn down to be used for horseshoe pitching courts in some of Portland's parks. ${ }^{3}$

The transition between the Carroll Market and the Portland Public Market was far from seamless. Nearly six years passed between 1928 and 1934 in which debate, speculation, and controversy plagued the development of the waterfront project. In the end, though, when the new market opened its doors to the public, it was clear that this institution was different from Yamhill in more ways than size alone. The Portland Public Market was a rejection of the cultural and environmental processes that had shaped the Carroll Public Market. While the Carroll Market had been created from a cultural movement that in turn developed a new commercial environment along Yamhill, the waterfront market was intended to be the centerpiece of the downtown's extension toward the river regardless of the dissatisfaction it had cause among Yamhill supporters. The process had been reversed for the Portland Public Market, and there was an insistence that the building alone was enough to draw crowds as well as waterfront investors. In essence, planners expected to predict and create success by harnessing the support of one of Portland's cultural icons.

It is surprising that those elitist plans for the market stayed afloat during the country's worst economic depression. Elsewhere in the country, the Great Depression tested public involvement and funds for municipal markets, a progression that had begun as early as the mid-1920s. In Portland though, the Carroll Market remained comfortably profitable for twenty years until the end of 1933. In defiance of the new modern market, producers from Yamhill created a cooperative market in 1934 along the same street to continue the

3 “Yamhill Public Market Closes Down After 20 Years of Continuous Service," The Oregonian, January 9, 1934. 108 
Carroll Market's legacy. Their institution and many other businesses that began during the public market years lasted well into the 1960s.

This chapter is divided into two sections: A Going Public Market and The Lonely Palace of Wonders. The first section will highlight the planning of the PPM as well as detailing the cultural backlash that ensued. The debate took roughly six years, during which time opinions became starkly divided. The next section will describe the institution itself and how it failed to create a new commercial environment. As the largest public market in the United States, it certainly promised a great deal of potential but lacked the community backing to fulfill it. Ultimately, the PPM failed because it rejected the cultural foundation of the Carroll Public Market's community and believed that it could create a commercial environment without it.

\section{A Going Public Market}

Agreements for construction between the city of Portland and the Portland Public Market Company began as early as 1928. Initially, it was believed that the producers along Yamhill would simply move into the new market. This assumption only lasted the two years it took to get money in order for the project. Financing for the market began with sale of stock and bonds to the total of one and a half million dollars. ${ }^{4}$ The money came from some of Portland's wealthiest parties and from those who owned land/property on or near the proposed market site, including First National Bank President Abbot L. Mills, the Meier and Frank Company, Frederick H. Strong, and U.S. National Bank President John C. Ainsworth,

${ }^{4}$ MacColl, The Growth of a City: Power and Politics in Portland, Oregon 1915-1950, 489. 
who was also the president of the City Planning Commission. The investment strategy was not unlike that which had created Portland's downtown district--even some of the same estates were involved. According to historian E. Kimbark MacColl, though, financing the project became increasingly complicated between 1928 and 1931, as investors backed out and the public reaction to the waterfront site became increasingly divided. ${ }^{5}$ One of the investors, Frederick H. Strong, even offered to personally fund the entire project as long as the city assumed control upon completion. Hesitancy prevented this prospect from ever being taken seriously, and it was an early bit of foreshadowing as to the amount of general confidence in the waterfront project.

The onset of the Great Depression bought the farmers along Yamhill more time during which they solidified a coalition. Yet, a major blow to their efforts came in August 1930 with the resignation of Commissioner Bigelow. He had defended the producers for roughly sixteen years and was a firm advocate of the Yamhill public market system. While he had opposed the waterfront site and the private ownership of the new market, his resignation letter said nothing of his political reasoning. His new job was not too dissimilar from his public role though, when he became the market manager of the privately-owned Grand Central Public Market on Portland's eastside. ${ }^{6}$ Just three months earlier on May 7, the farmers had begun their campaign to stop the new market with a petition to the city council from the Yamhill Public Market Producer's Association, the same group that had formed over a decade earlier to defend against the critiques of the Fair Price Committee. Even without Bigelow's voice the petition held significant weight, with roughly eighteen thousand market customers and two hundred and forty-six farmers. The petition railed against the new

${ }^{5}$ MacColl, The Growth of a City: Power and Politics in Portland, Oregon 1915-1950, 490.

6 "Bigelow Resigns As Commissioner," The Oregonian, August 7, 1930. 
market, believing that private ownership and higher rents would force out most of the smaller producers. The group also defended the Yamhill location as "the greatest attraction to tourist" traffic "to our city," threatening that patrons along Yamhill, "expressed the wish for the market to remain in the same vicinity, as they will not patronize it if put on Front Street." $^{\text {7 }}$

Confidence over the potential success of the new market was far from absolute, and for its supporters, proceeding with the plan hinged on vacating the farmers along Yamhill. This proved to be far more difficult than the Portland Market Company had originally anticipated. By October 1931, two additional plans were thrown into the controversy by T. W. Baker and the Central Municipal Market Company. ${ }^{8}$ The proposals were submitted to the newly formed Special Committee on Public Markets, which oversaw the construction and implementation of Portland's new public market building. Both plans suggested that patronage (and thus financial) success relied on remaining within the downtown and close to the original market site. The Central Municipal Market Company offered the most expensive option at roughly $\$ 2,400,000$ by constructing two buildings between Fourth and Fifth Streets on either side of Taylor. Another proposal by T. W. Baker opted for an entire city block spiral-sloped building between Fourth and Fifth and Yamhill and Taylor at a cost of $\$ 1,950,000$. In contrast, the PPM projected a cost of $\$ 1,472,132$, with roughly twice the amount of available retail space as the other two options. This was only possible because

\footnotetext{
7 Yamhill Public Market Producer's Association, “Carroll Market Petition,” May 22, 1930, Carroll Public Market Papers, A2000-004, City of Portland Archives, Portland, OR.

8 A. L. Barbur, "Three Proposals to the Special Committee on Public Markets," October 2, 1931, Special Committee Report Papers, A2000-029, City of Portland Archives, Portland, OR.
} 
waterfront property was dramatically cheaper than the downtown blocks. In both of the new proposals, the price of land equated to about 75 percent of the total costs. 9

In the end, though, the two central groups of either side of the debate looked to statistics outside of the costs for reassurance. For farmers along Yamhill, the real sticking points were location, rent, and the corporation's low dedication to producers. Because the waterfront market was the largest, it charged individual farmers fifty-five cents a day as opposed to the other proposals that asked for twenty-five cents. In the nearly twenty years of operation, the Carroll Market's rental fees had gone unchanged at fifteen cents a day. Supporters of the PPM focused on one key component of the Portland public market: parking. Over a third of the waterfront market's grand total space was devoted to auto storage, a concept that was good for the market but also hopefully good for the downtown. In the end, cost and traffic relief were cited as reasons for favoring the waterfront plan.

Between 1930 and 1933, multiple groups and individual citizens weighed in on the deliberation. Not surprisingly, groups like the Portland Grocers and Merchants Association as well the Portland Downtown Association, who had opposed the premise of the Carroll Public Market for years, both favored the Front Street Site. ${ }^{10}$ Others like the Housewives Council, the Pomona Grange, the Pleasant Valley Grange, and the Oregon Club all protested the waterfront market with either petitions or at city council meetings. These associations constituted an integral part of the Carroll Public Market's cultural community, and some had even been present during the campaign to create the market nearly twenty years earlier. Nongroup Portlanders were strongly divided as well, and many of the city's newspapers either

\footnotetext{
9 The Portland Public Market Company’s cost for acquiring waterfront property was $\$ 385,560.00$, just over a fifth of the total construction costs. Barbur, "Three Proposals to the Special Committee on Public Markets." 10 "Construction of New Public Market," Public Market Council Documents, A2000-024, City of Portland Archives, Portland, OR.
} 
took a stance or ran articles on both sides. On March 26, 1932, the Oregon Journal asked "the people" to speak on the debate in a segment they called, "for and against." George Moyer Sr. supported Front Street, “The present business center of Seattle is farther from Pike Street [Public] Market than Portland's business center is from the Morrison Bridge," he explained. According to Moyer, if success hinged on proximity to the retail core, the waterfront site had nothing to worry about it because other public markets, like Seattle's had succeeded with more distance. G. Y. Edwards opposed the Front Street site by stating that if the location remained in the downtown, it could be "accessible for all." ${ }^{11}$ By the 1930s, downtown, the central business district, and the retail core were interchangeable terms for many Portlanders and the assumption of its power to generate business had essentially become a fact. Even with the Portland Public Market's dedication to free automobile parking, location had become the point of contention.

Despite the protests, the Portland Public Market Company quietly got approvals from the city council for construction permits and financing agreements in 1931. On October 28, 1931, the Special Committee on Public Markets finalized an agreement with the company stating that the city would assume control once the business was a "going public market." 12 This ambiguous language later became a point of contention, even threatening the contract that had already been approved by the city of Portland, yet it appeared as though nothing could stop the waterfront plan even though the Bartholomew Report, which had been issued by the City Planning Commission five years earlier, directly opposed the

\footnotetext{
11 "Letter from People Contending and Opposing Front Street Site," Oregon Journal, March 26, 1932.

12 "Construction of New Public Market," Public Market Council Documents, A2000-024, City of Portland Archives, Portland, OR.
} 
waterfront market. ${ }^{13}$ Even the Planning Commission was willing to ignore this aspect of the report. It became clear to many Portlanders that more plans were at work than the public knew. Between February and April 1932, Mayor Baker, Commissioner Earl Riley, local merchant Mike Rogoway, and attorney Alfred A. Hampson were all indicted on counts of bribery during negotiations with the Public Market Company. ${ }^{14}$ The cases were later thrown out for lack of evidence, but the damage had already been done. What had already seemed suspicious now reeked of back room deals. While many investors had pulled out because of the Depression, the PPM project continued to lose investments during the aftermath of the Public Market fiasco.

The lack of willing investors and funds remained the primary obstacle to the project, but help from the federal government came in the beginning of 1932, with the establishment of the Reconstruction Finance Corporation (RFC). The entity was primarily formed to assist banks and railroads, but the city of Portland was able to secure a project loan of $\$ 775,000$ from the RFC in October 1932, over half of the projected total construction costs. ${ }^{15}$ Considering the times and the scandal, the PPM likely could not have generated the investments for the project if not for the RFC.

The Portland Market Company began construction promptly in June 1933 but not before a city election dramatically changed the council's stance on the waterfront market plan. The opposition group was led by Commissioner Jake Bennett and supported by recently elected Mayor Joseph Carson, Commissioner Ormond Bean, and Commissioner

\footnotetext{
${ }^{13}$ Harland Bartholomew's report proposed the construction of a public waterfront park. This became one of the only elements of the plan to be implemented but it took several decades to come to fruition. MacColl, The Growth of a City: Power and Politics in Portland, Oregon 1915-1950, 499.

14 MacColl, The Growth of a City: Power and Politics in Portland, Oregon 1915-1950, 493.

15 MacColl, The Growth of a City: Power and Politics in Portland, Oregon 1915-1950, 493-494.
} 
Earl Riley, who had been the lone voice against the plan in previous years. In that same year, those who had committed themselves to the Carroll Public Market emboldened their stance against the waterfront plan, forming their own opposition group against the Portland Market Company. During the latter half of the year, roughly two hundred of the market's farmers formed the Farmers' Market Association and began planning the construction of Cooperative Market on one of the busiest intersections along Yamhill street. This new institution allowed the producers that had existed along Yamhill to continue. The co-op stood as an institution of defiance that was defined by its attachment to the location and the sustainment of the Carroll Market's producer and consumer community.

As the Portland Public Market became a reality between 1926 and 1933, its supporters worked to contrast it with the cultural foundation as well as the location of the Carroll Public Market. Compromise had not been an option, because the new market was part of significantly larger scheme for downtown investment and planning. While the push and pull of the debate did little to hinder its implementation, it had the effect of solidifying a coalition against the waterfront market. Commissioner Bennett became one of the most vocal adversaries of the Portland Public Market Company, and in later years he even supported the allowance of self-run "farmers markets" modeled after the Carroll Public Market. Commissioner Bean was able to push back the removal date of the market from December 15, 1933 to January 1,1934, allowing the farmers more time to ensure a seamless transition between the curbside market and the new co-op. ${ }^{16}$ Nevertheless, the Portland Public Market was completed in just five months and opened on December 15, 1933, an impressive feat considering the size.

16 “January 1 Date Set for Removal of Yamhill-Street Public Market," The Oregonian, November 24, 1933. 
Just two days after the removal of the farmers and sheds along Yamhill street, Bennett began a city council action to refuse acceptance of the Portland Public Market. The commissioner claimed that the market contract had been made without proper oversight and recommended letting the people of Portland see it. His January 3, 1934, statement read:

\begin{abstract}
My suggestion therefore is, that if the promoters of this undertaking are desirous of having the City take over the Market Building and operate the same, that an ordinance referring the whole matter to the people for their vote at the May election should be passed by the council at this time. ${ }^{17}$

Following Bennett's letter, the company found itself in "constant litigation, either suing the city or being sued by the city or various taxpayer groups" until $1946 .{ }^{18}$ The entire fiasco was a complete mess for everyone involved. There was hardly a moment over the years that the producers and consumers of the Carroll Public Market were not actively being ignored, and because of this, the waterfront project never amassed the customer base that
\end{abstract} had existed along Yamhill.

The Lonely Palace of Wonders

Considering the degree and amount of opposition that had accumulated over the previous six years, it was no surprise that the Portland Public Market Company held a great deal of anxiety about the opening. During the month of December 1933, Portlanders were bombarded with ads showcasing the "World’s Most Modern Food and Merchandise Mart."19 The largest of these, was a four page centerfold that detailed the "Palace of Wonders" with

\footnotetext{
${ }^{17}$ Statement of J. E. Bennett in Re Front Street Market, January 3, 1934, Public Market Correspondence Papers, A2010-009, City of Portland Archives, Portland, OR.

18 MacColl, The Growth of a City: Power and Politics in Portland, Oregon 1915-1950, 496.

19 Portland Public Market Company, "Portland's Colossal Food and Merchandise Market," Placed in The Oregonian in mid-December 1933, Public Market Folders, Oregon Historical Society, Portland, OR.
} 
floor plans, construction details, sanitary and technological reassurances, and blatant

propaganda. The pamphlet posed the following question to the consumer:

Certainly no such assembly center for the fruits of an empire has ever before been raised by the hands of man. Could any of the ancients who wrote with gusto of foods delighting the palate and satisfying the soul have ever walked in a garden so heavily laden with delicacies as the great Pacific Northwest?20

Oregon, let alone the Pacific Northwest, the ad proposed, were far from the only location that merchandise came from, for "Treasure troves of the Pacific Ocean [had] been raided," and the market had "everything in the food line the world [had] to offer."

During the 1920s and 1930s, The Oregonian stood decidedly in support of the waterfront market and ran articles almost every other day during its inaugural month either detailing the size, the technology, the construction process, or the sheer wonder of it all. Features like, "Portland's Marvelous New Million Dollar Public Market Opens" and "Market World's Finest," both ran the day before opening and complimented the multiple-page length ads advocating for the new public market. ${ }^{21}$ The Portland Public Market was an exciting project and it promised a great deal as an institution that embodied the values of modernity and urban planning. There was little doubt, even from Yamhill's producers, that the PPM was too grand or too modern. Criticism was almost exclusively targeted at the location and the new market's private ownership. What appeared to be a great deal of expectation, however, also indicated a tremendous amount of unease.

The Portland Public Market actively distanced itself from Yamhill's producers, ultimately severing a relationship with their consumers. The market even attempted to replicate the civic festivities that had occurred on opening day of the Carroll Public Market

${ }^{20}$ Portland Public Market Company, "Portland's Colossal Food and Merchandise Market."

${ }^{21}$ Portland Public Market Ad, "Portland's Marvelous New Million Dollar Public Market Opens," The Oregonian, December 14, 1933; and "Market World's Finest," The Oregonian, December 14, 1933. 
by planning a "Mammoth Public Reception" lasting three days with promises of "Plenty of Music and Fun."22 The event proposed "a hundred wonderful sales all rolled into one! Ten thousand gifts alone for youngsters! Galaxies of Lights! Entertainment every breathless hour!' Considering the hype and ostentatious descriptions, it is surprising that the market's opening commemoration did manage to omit the most important component of the Carroll Market's opening parade, authentic civic pride. While the Carroll Market had amassed "thousands" of representatives of commercial organizations, granges, local business concerns, and booster clubs, the Portland Public Market was only able to collect four city council members including Mayor Carson and ex-mayor Baker. ${ }^{23}$

Beyond its rejection of Yamhill's cultural foundation, the commercial environment inside and outside of the PPM was drastically different from its predecessor. The institution emanated notions of another world of food merchandising that contrasted rather harshly with Yamhill Street. Specifically, the "Huge City of Foods and Merchandise" displayed a distrust of local farmers. Besides the fact that there were over twice as many sales people for shops, restaurants, and concessions as there were produce farmers and associations, the market employed modern technology to guarantee "honest" transactions. Every farmer stall was outfitted with new springless scales to ensure "honest weight, not a catch phrase but the actual watchword in every transaction."24 If customers were not entirely satisfied, they could use one of the "two large duplex scales" to make their own check of the weight. If they were

\footnotetext{
22 Portland Public Market Ad, "Portland's Marvelous New Million Dollar Public Market Opens." The Oregonian, December 14, 1933.

23 "Pageant in which Thousands Participate Marks Formal Opening of Portland Public Market on Yamhill Street," The Morning Oregonian, May 17, 1914.

${ }^{24}$ Portland Public Market Company, "Portland's Colossal Food and Merchandise Market."
} 
still unconvinced, the corporation also "conducted periodic inspections of all weighing devices as a safeguard."

Farmers were not allowed to pass their produce through the customer doors and upon arrival "every bit of perishable merchandise [was] subject to strict inspection... and any that is sub-standard [could] be ordered off the stands without appeal." ${ }^{, 25}$ Refrigerated storage was also guaranteed to be insect, rat, and vermin proof and was situated upstairs "amid sunshine and fresh air, far from cellar dark and dampness," like the shared storage that had been used along Yamhill. ${ }^{26}$ There was an assumption among the new market's promoters that consumers rightfully distrusted their farmer and needed a system of protection to certify that they would not be taken advantage of.

The Portland Public Market was as big as its promoters claimed. It nearly covered the distance between the Hawthorne and Morrison bridges at six hundred and sixteen feet in length with enough free parking spaces for six hundred and fifty automobiles. ${ }^{27}$ The parking was a main attraction for many city planners, with roughly forty-three percent of downtown traffic coming from either the Hawthorne or Morrison bridges, planners hoped that the market would be the first stop before walking through the downtown. The four million cubic foot interior held nearly every type of shop and restaurant imaginable, as well as many oddities including an optician, a paper bag store, a public stenographer, a wheelerie, a church

25 Portland Public Market Company to City Council concerning Data on Portland's Municipal Public Market, No date, 1933/1934, Public Market Committee Correspondence 1933-1934, City of Portland Archives, Portland, OR.

${ }^{26}$ Portland Public Market Company, "Portland's Colossal Food and Merchandise Market."

${ }^{27}$ Portland Public Market Company to City Council concerning Data on Portland's Municipal Public Market, No date, 1933/1934, Public Market Committee Correspondence 1933-1934, City of Portland Archives, Portland, OR. 
sale booth, and a fuel depot (which was not to be confused with the gas station that also resided in the building). ${ }^{28}$

The emphasis on modern convenience and technology dominated the ads, as well as the layout of the market. Unlike the Carroll Public Market, the PPM directed its efforts toward the automobile shopper, inadvertently alienating the pedestrian shopper that wished to move effortlessly between the waterfront and retail core. Decades later, H. A. Herzog wrote to the editor of the Oregon Journal on the failure of the waterfront site stating, "It was doomed to failure because people would not cross a race track [Front Street] to shop. ${ }^{29}$ The experience of shopping at the market was markedly different as well; the 'Handy Ann' shopping cart reinforced the notion of a one-stop shop for Portland's "housewives and 'market trained' husbands." ${ }^{30}$ Elevators and shopping attendants made it possible to purchase and bring home more goods than may have ever been conceived of by the Yamhill Street consumer. The promoters of the new market defined it as an easy and convenient shopping experience, a new focus considering that Yamhill was valued first for its absence of middlemen and then later for its lower prices.

Many hopes and dreams for the waterfront had been attached to the market's construction. The Portland Public Market Company claimed as much in their market projections data sheet sent to the Special Committee on Public Markets that stated the following:

\footnotetext{
28 The company also gave site preference to the most established shops throughout Portland; ensuring a competitive edge over newer businesses. The emphasis on allowing only the "highest grade" shops closed opportunities to smaller and newer businesses. Portland Public Market Company, "Portland's Colossal Food and Merchandise Market."

${ }^{29}$ From MacColl, The Growth of a City: Power and Politics in Portland, Oregon 1915-1950, 496: H. A. Herzog, "Letter to the Editor," The Oregon Journal, December 28, 1968.

30 Portland Public Market Company, "Portland's Colossal Food and Merchandise Market."
} 
This market [is] the first unit in the re-development of a new marketing business section in the seawall district...

It is anticipated from the history of other markets that it will transpose non-productive automobile traffic into buying pedestrian traffic extended over a period of six blocks, and will result in the development of new type[s] of merchandising endeavors in the district south of Fifth Street. (that means that non productive property at the present time will gradually take on a retail atmosphere). ${ }^{31}$

Of course, this is exactly what had happened along Yamhill Street. Market promoters of the PPM expected the building to have inherent cultural and consumer attraction; businesses would grow around it and as a result a new commercial environment would be made. These hopes were not limited to the market's promoters. In February 1934, two months after the opening of the Portland Public Market, Ben Gadsby of the forty-year old William Gadsby \& Sons Furniture located on First and Washington claimed that, "The opening of the great new Portland public market on Front Ave. has been the signal for a revival of trade hereabouts. When we think of the possibilities... we look for more new buildings and new business enterprises."32 Gadsby was not the only inspired Portland business owner. Max and Isadore Goldberg opened the Seawall Public Market on Front and Yamhill directly across from Portland Public Market in January 1934. "We believe our market will help draw traffic to Front Street... and because of the advantages of location, believe a market now is the logical business for the property," Isadore Goldberg remarked. ${ }^{33}$ While some development occurred along Front Street, however, no commercial construction took place along the waterfront, and the hopes of generating a new commercial district never came to fruition.

From the very beginning, moreover, the Portland Public Market never filled its tenant quota. It never had a profitable month, and with the ongoing legal conflict with the

\footnotetext{
31 Portland Public Market Company to City Council concerning Data on Portland's Municipal Public Market, No date, 1933/1934, Public Market Committee Correspondence 1933-1934, City of Portland Archives, Portland, OR.

32 "Furniture Trade Gains," The Oregonian, February 4, 1934.

33 "New Market to Open," The Oregonian, January 15, 1934.
} 
city, the market owners knew they were in trouble early on. By the end of December 1937, the Portland Market Company had A. E. Doyle and Associates draw up blueprints for restructuring the building as a sale back to the city. The new layout shrunk the public market down to an eighteen thousand square foot space on the first floor (a fraction of what it had been) and dismissed every restaurateur, merchant, and physician. The new building layout planned to house some of Portland's jails, police and fire departments, trial courts, dock commission, and hospitals among other public utilities. ${ }^{34}$ While the preliminary blueprint was never implemented, it suggests a scrambling, almost frantic understanding of the situation from the Portland Public Market Company. It took just a few years for the "world's most modern" and the nation's largest public market to fail the grand expectations and planning that had gone into it for over six years.

The Portland Public Market shut down in 1942 amid an ongoing legal battle with the City of Portland over ownership. Two years later in June 1946, the building was sold to the Oregon Journal and Oregon's State Supreme Court determined that the city was not the liable owner because the company had never established a "going public market." 35 In the end though, both parties were charged for damages due to failure to carry out contractual obligations. It was a loss on all accounts, but fortunately for Portlanders, other privatelyowned forms of public markets continued to exist around Portland.

As for the producers of the Carroll Market, their rebellious institution, the Farmers' Cooperative Market, held its formal dedication on January 20, 1934. The "high point" of the ceremony was the announcement of winners of the "Why I Like to Shop on Yamhill Street"

\footnotetext{
34 "Preliminary Blueprint for Alterations from A. E. Doyle and Associates to the Public Market Building," December 2, 1937, Oregon Historical Society, Portland, OR.

${ }^{35}$ MacColl, The Growth of a City: Power and Politics in Portland, Oregon 1915-1950, 496-499.
} 
letter contest. ${ }^{36}$ The street had taken on a different meaning to the producers, consumers, and merchants that conducted business there. Cultural and civic value had been endowed into the commercial environment, creating a unique place and community. Promoters of the Portland Public Market had failed to understand that they were actively rejecting the cultural values of the institution as well as the place that held meaning for the producers and consumers of the Carroll Public Market. This was best communicated in an editorial article of The Oregonian on January 31, 1941, titled “The Unknown Factor":

...it would be wise before engaging in large undertakings whose success dependent on the trade or patronage of many people, to call in a business psychologist, if there is such a thing.

The success of the public market building depended on its ability to centralize under its roof a very substantial part of the retail buying and selling of household food supplies. It was expected to do that, and it was expected, too, that Yamhill Street would be the principle sufferer. On the basis of its presumptive attractions the great market building could be figured out a sure winner.

But Yamhill refused to give up as a market street, though stalls outside the curbs were removed. And a large part of the public long accustomed to buying in Yamhill Street continued to buy from stores and markets that were on private property. The un-assessable human factor, the ' $\mathrm{X}$,' the unknown quantity in business affairs, kept the great market building below the financial prospectus that once seemed as sure as shooting to be realized. ${ }^{37}$

The Carroll Public Market certainly had many things that the Portland Public Market did not. Their contrasting cultural values and commercial environments give the historian some clues as to what made them valuable to consumers and producers in Portland during the early twentieth century. Whether or not all of Yamhill's consumers subscribed to the advocates' values, many saw the street as Portland's downtown market avenue and as a result, it remained so for decades after the Carroll Public Market's final day.

36 "Farmer's Market Opens," The Oregonian, January 21, 1934.

${ }^{37}$ Editorial, "The Unknown Factor," The Oregonian, January 31, 1941. 


\section{Conclusion}

For four decades after the Carroll Public Market shut down, Yamhill Street contained some of the same vendors that had rallied around the original market. In March 1975, two of the last vendors, Frank Frederick and Ray Sadis, ended their careers in response to downtown developmental plans to destroy several buildings on the three hundred block of Yamhill. ${ }^{1}$ Frederick worked the "market areas" on Yamhill for fifty-one years while Sadis worked there for fifty five. According to an article in The Oregonian, customers during the interview mourned the loss of the markets of Yamhill with statements like, "downtown needs this place_closing it is a shame." Sadis claimed he would try retirement, but if he got too lonely he would “open up another market right around here somewhere [Yamhill Street]." During the same year, Gregg Olson and Robert Sutton of the State Historic Preservation Staff successfully designated the Yamhill District (roughly between Morrison to Taylor and Front to Third) as a historic district and completed nomination of the district in the National Register of Historic Places the following year. ${ }^{2}$ The district intended to protect the only ten buildings that remained from the nineteenth century. Yamhill from Third until Fifth streets had undergone re-development between 1942 and the 1960s, losing many of the older buildings that had been restored during the life of the Carroll Public Market.

As for the rural producers of Yamhill, they operated the Farmers' Cooperative Market for at least fifteen years, acting both as a continuation of the Carroll Public Market and something of a community center. ${ }^{3}$ Regular events and sales sponsored by some of the

\footnotetext{
1 John Guernsey, "Yamhill market owners to bow out," The Oregonian, March 30, 1975.

2 Tess. Uphill Downhill Yambill: The Evolution of the Yambill District in Portland, Oregon.

3 “America’s Wonders Dazzle Girl From Germany," The Oregonian, December 11, 1949.
} 
city's clubs maintained the civic culture that became an integral part of the market's attraction. The public market system also lived on to a lesser degree throughout East Portland with the establishment of at least three drive-in farmers markets (also known as Harvest Markets) during World War II in 1943. The markets were located at Twenty Fourth Street and Powell, Thirty Fourth Street and Division, and at 6110 N. E. Union Avenue. ${ }^{4}$ Each of them operated twice a week and farmers were charged a mere twelve dollars a year to sell produce. Producers were also subject to inspection by an official from the City Health Bureau. According to Portland's Commissioner of Finance, Kenneth L. Cooper, the Harvest Markets were created for three reasons:

The inadequacy of distribution through private channels, which tended toward exorbitant prices; the enormous surplus grown as a result of the plea by federal and municipal authorities for increased production of truck and fruit crops to replace those formerly produced by Jap truck gardeners; [and] the lack of gasoline and tires preventing householders from cruising the country and buying direct from the farmer as was customary prior to the war. ${ }^{5}$

While the Harvest Markets originated in different motivations, their principles certainly echoed those of the Carroll Public Market by targeting "exorbitant prices" of private groceries and by fulfilling the need to bring healthy "farm produce directly to consumers."

There is still more work to be done. The Carroll Market projected a legacy after it was demolished that began with the Farmers' Cooperative and the merchants of Yamhill, and was later continued by Japanese truck gardeners, the Harvest Markets, and other types of farmers' markets. Two decades later, beginning in 2000, a second campaign, led by Ron

\footnotetext{
${ }^{4}$ Commissioner Cooper to Mr. Arthur E. Goodwin concerning Market on Wheels, January 12, 1944, Public Market Front Street 1933-47 Papers, A2001-059, City of Portland Archives, Portland, OR.

${ }^{5}$ Commissioner Cooper to Hon. Robert S. Fredericks concerning Harvest Markets," November 26, 1943, Public Market Front Street 1933-47 Papers, A2001-059, City of Portland Archives, Portland, OR.
} 
Paul, began. ${ }^{6}$ In 2013, almost a century after the founding of the Carroll Public Market, the James Beard Public Market project is nearing its final stages. The new public market is named after James Beard, an eccentric chef and food writer during the 1940s and 1950s. Beard grew up in Portland and many of his early experiences with food came from visiting the public market of Yamhill Street. ${ }^{7}$ The new public market plan is seeking to create a Portland institution that acknowledges the history of the city and its citizens. The project website states that "We believe in preserving and building upon Portland's past Public Market history which connects the region's citizens to their fertile lands, their rural communities and the bountiful selection of locally grown foods." ${ }^{8}$ Many of these activities and ideas can be traced back to the Carroll Market, an institution and a place that became culturally valuable for many of Portland's citizens. Detailing the lasting impact of the establishment throughout the rest of the twentieth century remains a large gap in the history of Portland's public markets. More research is also needed to understand how and why the food merchants of Yamhill felt strongly connected to the street as a place for markets even after the municipal market left.

This thesis has sought to determine why and how the Carroll Public Market was successful and why its replacement, the Portland Public Market, could not reproduce the same feat. It may have appeared obvious to commentators during the 1940s and 1950s why

\footnotetext{
6 “The Process," James Beard Public Market Website, http://www.portlandpublicmarket.com/PortlandPublicMarket-TheProcess.html (accessed January 25, 2013).

${ }^{7}$ Portland is also experiencing a growth in the number of food carts, a smaller, cheaper, and more informal way of getting restaurant quality food. Currently, there are over one hundred and fifty food carts scattered throughout the city in clusters and alone. These carts capture some of the spirit of older public markets as they attempt to tighten the relationship between producers and consumers. Not unlike the Carroll Market, this growing food/restaurant culture may have a profound effect on Portlanders and their conceptualization of food in the coming decades. "A Writer Cooks," The Oregonian, May 3, 1964.

8 "Vision and Mission Statement," James Beard Public Market Website, http://www.portlandpublicmarket.com/pdxMkt-Vision.html (accessed on January 25, 2013).
} 
the Portland Public Market did not last. Most have pointed to the location or the times, particularly, the behemoth of a building that sat alone on the waterfront during the Depression with an expressway separating it from the downtown. Yet the building was designed to accommodate automobile traffic and if enough consumers supported it, it should have experienced some measure of success. More to the point, the promoters of the Portland Public Market were unable to realize that their institution constituted a symbolic denial of the Carroll Public Market and the market community that had grown around it along Yamhill Street. Promoters believed that the waterfront building alone could inspire development and the creation of a new commercial environment yet the Carroll Market had done this, and in a distinct and lasting way.

Advocates of the public market along Yamhill had history on their side. The institution was fashioned after decades of dissatisfaction from both rural producers and urban consumers. Through cooperative efforts they founded the market as a place to both celebrate and test their values. The public market's presence on Yamhill altered the street in two ways: the commercial environment was reinvigorated into a thriving business district, and the street was endowed with cultural value as a market district. All of this happened without formalized leadership or incentive, providing an impressive instance of community development. The Carroll Market was not without its problems. As a curbside pedestrian market it was unable to adjust to the pressures of a modernizing downtown or modern expectations of food distribution. To be clear though, it was shut down by the efforts of planners and supporters of the waterfront public market and not by the producers and consumers who sustained the operations for nearly twenty years. The market's demise was beyond its own control, but it didn't exist without social critiques. 
Despite its complicated position in Portland's downtown, the Carroll Public Market still served as a place of opportunity. Commissioner Bigelow's stance against associations and his decision to allow only local producers from Portland's agricultural hinterland created a market space that benefitted small or burgeoning farmers. Immigrant and ethnic populations also benefitted from market and often constituted more than half of the vendors along the curb. However, nativist fears complicated the equality of the market space when the Oregon Federation of Fraternal Societies pushed Bigelow to segregate the producers by "race" in 1920. The segregation ensured that "white" producers were given the most favorable real estate along Yamhill, ultimately pushing ethnic farmers toward the waterfront. While nativists sought to undermine the legitimacy of ethnic groups, the reality was that at the Carroll Public Market, like many other public markets in American cities during this time, minority farmers used the institution far more than many white farmers. In the following decades, most public markets lost support as new models and values of food distribution emerged but it was the chaotic and complex ethnic nature of the public market model that many retailers actively distanced themselves from. For a time though, places like the Carroll Public Market offered opportunity to all independent and local farmers.

The consumers' role in food retailing was also redefined as women exercised incredible degrees of influence over regulations and market operations. Food distribution in Portland and across the country underwent dramatic developments with pressure from housewife and consumer groups that focused on price, convenience, and standardization. Following the demise of many public markets during the 1930s, political consumerism in food retailing continued to shape the structures of food distribution. Women became the 
target of most food businesses, and it was during the early twentieth century through public markets that their power over consumerism in the American economy expanded.

Social constructions of community were changed at the market. Greater ethnic and racial neighborhood divisions were broken down albeit segregation at the market after 1920 defined their differences. Women were unquestioned in their roles as consumer advocates and ultimately led many of the changes in food distribution values. Rural and urban citizens united under a common interest and institution that tied them together as a single local region. These unintended historical experiences were all triggered by the anti-middlemen ideology of the public market. Along Yamhill, the market provided opportunities for many Portlanders to recast their economic, political and social roles in society

It is difficult to understate the fact that the creation and legacy of the public market hinged on the satisfaction of two groups: producers and consumers. During the life of the Carroll Public Market, these titles referred to rural farmers and urban consumers, identities that were shaped by incredible geographic and commercial developments in Oregon and across America during the nineteenth century. Both responded to the changes of the century in a variety of ways, but it was their political movements that paved the way for the idea of a public market system. In Oregon, both rural populists and urban progressives found shared value in municipally owned public markets, enough so that they cooperated for the establishment of one. Their values and ideas also inspired a number of privately owned public markets; these institutions remained a part of Portland's food retailing for much of the twentieth century although little historical work has been done on them.

Public markets of private and public ownership made their way to Portland in the early twentieth century because of a perceived need. Middlemen were considered 
unnecessary agents of distribution and parasites of the producer's profit. Consumers believed the middleman's role raised the price of food and also diminished the wholesomeness of the product because they complicated the process of distribution. These motifs are still addressed today through farmers' markets in Portland and around the country. The argument has evolved though, and while localism may be the rallying ideology, it is charged with many of the same values and dissatisfactions that producers and consumers of public markets felt in the early twentieth century. The Carroll Public Market had a lasting impact on certain groups of people and places in Portland because it responded to the dissatisfactions with middlemen directly and absolutely. As a result, the Carroll Market held value for many Portlanders, conjuring a sense of nostalgia and historical value in the succeeding years after its closure, something that the Portland Public Market never experienced. Denying the middleman a place in the public market on Yamhill was a strong stance, one that was not taken by most public markets in America during the early twentieth century. ${ }^{9}$ While the Carroll Public Market was ended on the first day of 1934, it altered the historical course of Yamhill Street for decades as well as shaping the ongoing relationship between producers and consumers in Portland.

${ }^{9}$ U. S. Bureau of Census, "Municipal Markets in Cities Having A Population of Over 30,000: 1918," Prepared by Sam L. Rogers, Washington, DC: Government Printing Office, 1919. 
Bibliography

Primary Sources

“Inside Portland's Million Dollar Market," ca. 1934, Oregon Historical Society, Portland, OR.

“Portland Waterfront 1912,” ca. 1912, Oregon Historical Society, Portland, OR.

“The Carroll Public Market Street Side,” ca. 1922-1934?, Oregon Historical Society, Portland, OR.

“The Farmers' Cooperative,” ca. 1934, Oregon Historical Society, Portland, OR.

“The Portland Public Market," ca. 1937, Oregon Historical Society, Portland, OR.

Bartholomew Report. 2012-35, 1932. City of Portland Archives, Portland, OR

Carroll Public Market. A2000-004, 1919 \& 1933. City of Portland Archives, Portland, OR.

City Planning Commission, “Age of Central Business District,” ca. 1932, Portland Planning and Sustainability, Historic Maps, http://www.portlandoregon.gov/bps/article/146722, accessed on February 28, 2013.

Correspondence 1914 - P - Public Market. A2000-003, 1914. City of Portland Archives, Portland, OR.

Early Debate and History of Portland's Farmers' Markets. A2001-059, 1947. City of Portland Archives, Portland, OR.

Evening Telegram, 1912-1914.

Major Traffic Street Plan Boulevard and Park System for Portland, Oregon. 7700-02, 1921. City of Portland Archives, Portland, OR.

Oregon Journal, 1932-1968.

Oregonian, 1892-1975.

Public Market Committee Correspondence. A2001-055, 1934. City of Portland Archives, Portland, OR.

Public Market Correspondence, A2010-019, 1934. City of Portland Archives, Portland, OR.

Public Market Correspondence. A2010-019, 1946. City of Portland Archives, Portland, OR. 
Public Market Vertical Files. Oregon Historical Society, Portland, OR.

Report from the Special Committee on Public Market. A2000-029, 1931. City of Portland Archives, Portland, OR.

The Plan-It. 7702-02, 1927-39. City of Portland Archives, Portland, OR.

U. S. Bureau of Census. "Municipal Markets in Cities Having A Population of Over 30,000: 1918.” Prepared by Sam L. Rogers. Washington, DC: Government Printing Office, 1919.

\section{Secondary Sources}

"Fred Meyer History." Fred Meyer Corporation Website. http://www.fredmeyer.com/company information/pages/history.aspx (accessed on January 25, 2013).

"The Process." James Beard Public Market Website. http://www.portlandpublicmarket.com/PortlandPublicMarket-TheProcess.html (accessed January 25, 2013).

"Vision and Mission Statement." James Beard Public Market Website. http://www.portlandpublicmarket.com/pdxMkt-Vision.html (accessed on January $25,2013)$.

Abbott, Carl. "Greater Portland: Experiments with Professional Planning, 1905-1925." The Pacific Northwest Quarterly 76, no. 1 (January 1, 1985): 12-21.

Abbott, Carl. Portland in Three Centuries: The Place and the People. Corvallis: Oregon State University Press, 2011.

Abbott, Carl. Portland: Planning, Politics, and Growth in a Twentieth Century City. Lincoln: University of Nebraska Press, 1983.

Blee, Lisa. "Completing Lewis and Clark's Westward March: Exhibiting a History of Empire at the 1905 Portland World's Fair." Oregon Historical Quarterly 106, no. 2 (July 1, 2005): 232-253.

City of Portland: Bureau of Planning. "Urban Design Assessment: Central Portland Plan (Section B1: Portland's Great Plans).” http://www.portlandoregon.gov/bps/article/218810 (accessed January 25, 2013).

Cochran, John S. "Economic Importance of Early Transcontinental Railroads: Pacific Northwest." Oregon Historical Quarterly 71, No. 1 (March 1, 1970): 26-98. 
Coelho, Philip R. P., and Katherine H. Daigle. "The Effects of Developments in Transportation on the Settlement of the Inland Empire." Agricultural History 56, no. 1 (January 1, 1982): 22-36.

Cronon, William. Nature's Metropolis: Chicago and the Great West. New York: W. W. Norton \& Company, 1991.

Deutsch, Tracy. Building a Housewife's Paradise: Gender, Politics, and American Grocery Stores in the Twentieth Century. Chapel Hill: University of North Carolina Press, 2010.

Donofrio, Gregory Alexander. "Feeding The City." Gastronomica: The Journal of Food and Culture. Vol. 7, No. 4 (Fall 2007): 30-41.

Duruz, W. P. "Notes on the Early History of Horticulture in Oregon: With Special Reference to Fruit-Tree Nurseries." Agricultural History 15, no. 2 (April 1, 1941): 8497.

Edited by David Powers. Ankeny's New Market and Theater. Portland: Oregon Historical Society, 1976.

Eigo, George. A Market for the City: The History of Portland's Public Market. Portland: Oregon Historical Society, 2002.

Farnham, Wallace D. "The Development of an Oregon County, 1852-1890: Mines, Farms, and a Railroad." Pacific Historical Review 25, no. 1 (February 1, 1956): 29-45.

Fogelson, Robert M. Downtown: Its Rise and Fall, 1880-1950. New Haven: Yale University Press, 2001.

Gibson, James R. Farming the Frontier: The Agricultural Opening of the Oregon Country 1786-1846. Seattle: University of Washington Press, 1985.

Johansen, Dorothy. Empire of the Columbia a History of the Pacific Northwest,. 2nd ed. New York: Harper \& Row, 1967.

Johnston, Robert D. "The Single Tax." The Oregon Encyclopedia. Oregon Historical Society. http://www.oregonencyclopedia.org/entry/view/single tax/ (accessed January 25, 2013).

Johnston, Robert. The Radical Middle Class: Populist Democracy and the Question of Capitalism in Progressive Era Portland, Oregon. Princeton N.J.: Princeton University Press, 2003.

Lipin, Larry. Workers and the Wild: Conservation, Consumerism, and Labor in Oregon, 1910-30. Chicago: University of Illinois Press, 2007.

MacColl, E. Kimbark, and Harry H. Stein. Merchants, Money and Power: The Portland Establishment 1843-1913. Portland: The Georgian Press Company, 1988. 
MacColl, E. Kimbark. The Growth of a City: Power and Politics in Portland, Oregon, 1915-1950. Portland: The Georgian Press, 1979.

MacColl, E. Kimbark. The Shaping of a City: Business and Politics in Portland, Oregon, 1885-1915. Portland: The Georgian Press Co., 1976.

Mayo, James M. “The American Public Market.” Journal of Architectural Education, 45, no. 1 (November 1, 1991): 41-57.

McClintock, Thomas C. "Seth Lewelling, William S. U'Ren and the Birth of the Oregon Progressive Movement." Oregon Historical Quarterly, Vol. 68, No. 3 (September, 1967), 196-220.

Meinig, D. W. The Shaping of America. a Geographical Perspective on 500 Years of History Continental America, 1800-1867. New Haven: Yale University Press, 1993.

Morales, Alfonso. "Public Markets as Community Development Tools." Journal of Planning Education and Research, (February 25, 2009).

Paul, Rodman W. "After the Gold Rush: San Francisco and Portland." Pacific Historical Review 51, no. 1 (February 1, 1982): 1-21.

Postel, Charles. The Populist Vision. New York: Oxford University Press, 2009.

Reed College (Portland, Or.), and Bernard Falk. Populist Progressivism: Popular Democracy in Oregon, 1892-1910, 2004.

Reed College (Portland, Or.), and Robert Markell. Progressivism in the Country: The Smith-Lever Act, 1998.

Schwantes, Carlos. The Pacific Northwest: an interpretive history. Lincoln: University of Nebraska Press, 1989.

Stoll, Steven. Larding the Lean Earth: Soil and Society in Nineteenth-Century America. 1st ed. New York: Hill and Wang, 2002.

Tangires, Helen. Public Markets and Civic Culture in Nineteenth Century America. Baltimore: John Hopkins University Press, 2002.

Tess, John M. Uphill Downhill Yambill: The Evolution of the Yambill District in Portland, Oregon.

Washington, DC: National Trust for Historical Preservation, 1977.

Trachtenberg, Alan. The Incorporation of America: Culture and Society in the Gilded Age. New York: Hill and Wang, 2007. 
Unruh, John David. The Plains Across: The Overland Emigrants and the Trans-Mississippi West, 1840-60. Chicago: University of Illinois Press, 1979.

US Bureau of Census. "Population of the 100 Largest Urban Places." Washington, DC: Government Printing Office, June, 1998. http://www.census.gov/population/www/documentation/twps0027/tab12.txt (accessed on January 25, 2013).

US Bureau of Census. "Population Statistics for Portland, OR (1860-1890).” Washington, DC: Government Printing Office.

http://www.census.gov/prod/www/abs/decennial// (accessed January 25, 2013).

US Bureau of Census. "Urban and Rural Population: 1900 to 1990." Washington, DC:

Government Printing Office, October, 1995

http://www.census.gov/population/www/censusdata/files/urpop0090.txt (accessed on January 25, 2013).

Winther, Oscar. The Great Northwest: A History. 2nd ed. New York: Knopf, 1950.

Wong, Marie Rose. Sweet Cakes, Long Journey. Seattle: University of Washington Press, 2005. 